\title{
Anti-acetylcholine receptor autoantibodies in myasthenia gravis : pathogenicity and specificity related to their structure
}

Citation for published version (APA):

Meng, F. (2000). Anti-acetylcholine receptor autoantibodies in myasthenia gravis : pathogenicity and specificity related to their structure. [Doctoral Thesis, Maastricht University]. Universiteit Maastricht. https://doi.org/10.26481/dis.20010510fm

Document status and date:

Published: 01/01/2000

DOI:

10.26481/dis.20010510fm

Document Version:

Publisher's PDF, also known as Version of record

Please check the document version of this publication:

- A submitted manuscript is the version of the article upon submission and before peer-review. There can be important differences between the submitted version and the official published version of record.

People interested in the research are advised to contact the author for the final version of the publication, or visit the DOI to the publisher's website.

- The final author version and the galley proof are versions of the publication after peer review.

- The final published version features the final layout of the paper including the volume, issue and page numbers.

Link to publication

\footnotetext{
General rights rights.

- You may freely distribute the URL identifying the publication in the public portal. please follow below link for the End User Agreement:

www.umlib.nl/taverne-license

Take down policy

If you believe that this document breaches copyright please contact us at:

repository@maastrichtuniversity.nl

providing details and we will investigate your claim.
}

Copyright and moral rights for the publications made accessible in the public portal are retained by the authors and/or other copyright owners and it is a condition of accessing publications that users recognise and abide by the legal requirements associated with these

- Users may download and print one copy of any publication from the public portal for the purpose of private study or research.

- You may not further distribute the material or use it for any profit-making activity or commercial gain

If the publication is distributed under the terms of Article $25 \mathrm{fa}$ of the Dutch Copyright Act, indicated by the "Taverne" license above, 
Anti-Acetylcholine Receptor Autoantibodies in Myasthenia Gravis

Pathogenicity and specificity related to their structure 
In de drukkosten van het proefschrift werd bijgedragen door de Internationale Stichting Alzheimer Onderzoek 


\section{Anti-Acetylcholine Receptor Autoantibodies in Myasthenia Gravis}

Pathogenicity and specificity related to their structure

\section{PROEFSCHRIFT}

ter verkrijging van de graad van doctor aan de Universiteit Maastricht,

op gezag van de Rector Magnificus, Prof. Dr. A.C. Nieuwenhuijzen Kruseman, volgens het besluit van het College van Decanen,

in het openbaar te verdedigen

op donderdag 10 mei 2001 om 16.00 uur

door

Fanping Meng 


\section{Promotors:}

Prof. Dr. J. Troost

Prof. Dr. H. W. M. Steinbusch

\section{Co-promotor:}

Dr. M. H. De Baets

\section{Beoordelingscommissie:}

Prof. Dr. F. C. S. Ramaekers (voorzitter)

Prof. Dr. J. W. Cohen Tervaert

Prof. Dr. F. Spaans

Prof. Dr. P. Stinissen (Limburgs Universitair Centrum, Diepenbeek)

Dr. J. Verschuuren (Leids Universitair Medisch Centrum) 


\title{
Contents
}

\begin{abstract}
Abbreviations $\quad 6$
\end{abstract}
$\begin{array}{ll}\text { Introduction } & 7\end{array}$

Chapter 1 Production and characteristics of anti-acetylcholine receptor monoclonal antibodies in mice

Chapter 2 Pathogenicity and sequence analysis of monoclonal antibodies directed against the main immunogenic region of acetylcholine receptor

Chapter 3 Paratope mapping and sequence analysis of monoclonal antibodies directed against the $\alpha$-bungarotoxin binding site of acetylcholine receptor

Chapter 4 Construction and characterization of a single chain antibody fragment derived from thymus of a patient with myasthenia gravis

Chapter 5 Experimental autoimmune myasthenia gravis in mice expressing human immunoglobulin loci (HuMAb-Mice)

Summary and general discussion 


\section{Abbreviations}

$\alpha-\mathrm{BT}$

AChR

CDR

CFA

$\mathrm{CH}$

CL

D gene

EAMG

ELISA

$\mathrm{Fab}$

HRP

IFA

IMAC

JH

$\mathrm{J} \kappa$

mAbs

MG

MIR

PBS

PCR

RIA

$\mathrm{ScFv}$

SDS-PAGE

$\mathrm{VH}$

VL

$\alpha$-bungarotoxin

acetylcholine receptor

complementarity determining region

Complete Freund's Adjuvant

heavy chain constant region

light chain constant region

diversity gene

experimental autoimmune myasthenia gravis

enzyme-linked immunosorbent assay

antigen binding fragment

horseradish peroxidase

Incomplete Freund's Adjuvant

immobilized metal affinity chromatography

heavy chain joining gene

$\kappa$ chain joining gene

monoclonal antibodies

myasthenia gravis

main immunogenic region

phosphate buffered saline

polymerase chain reaction

radioimmunoassay

single chain variable fragment

sodium dodecyl sulfate-polyacrylamide gel electrophoresis

heavy chain variable region

light chain variable region 


\section{Introduction}

\section{Myasthenia gravis}

Myasthenia gravis (MG) is an organ-specific autoimmune disease mediated by autoantibodies directed against acetylcholine receptor (AChR) on postsynaptic membrane in neuromuscular junction[1,2]. The first description of patients with MG-like symptoms was made by an English physician Thomas Willis in 1672[3] and the name myasthenia gravis was introduced in 1895 by Jolly. However, the autoimmune nature of MG had not been proposed until 1960s when Simpson and other authors noticed that high frequency of thymus abnormalities appeared in MG patients, components in sera of MG patients could damage nerve and muscle tissues, and serum complement levels were lower in MG patients[4-6]. In 1973, Patrick and Lindstrom first demonstrated the autoimmune nature of $\mathrm{MG}$ in experimental rabbits immunized with AChR isolated from electric eel resulting in muscular weakness which resembled human MG[7]. Since then much information about the pathogenetic mechanisms has been revealed[8].

The clinical signs and symptoms in MG result from loss of functional AChR which is entirely antibody-mediated[9]. Anti-AChR antibodies are detectable in approximately $85 \%$ - $90 \%$ of the MG patients, whereas the other seronegative MG patients (approximately 10\% - 15\%) may caused by antibodies against other membrane proteins in the synapse including muscle-specific receptor tyrosine kinase (MuSK) (A. Vincent, personal communication) or by a non-immunoglobulin factor[10]. Thymic hyperplasia and thymomas are found in $75 \%$ of the MG patients[11]. Further study on MG thymus shows that the thymus contains components necessary for production of autoantibodies against AChR[12-15]. 
The prevalence of MG is 60-70 per million and annually 2.5-9.8 per million[16]. Many MG patients develop generalized MG and approximately $15 \%$ of the MG patients remains ocular MG (only ocular muscle weakness). Presently, there is no specific immunosuppressive therapy for MG. Although the prolonged nonspecific immunosuppressive therapies currently used in treatment of MG can control MG to some extent and reduce its mortality[17], there are still some significant side effects.

\section{Acetylcholine receptor}

Muscle-type AChR in neuromuscular junction is a complex transmembrane glycoprotein of molecular weight $290 \mathrm{KD}$, consisting of five subunits in a stochiometry $\alpha_{2} \beta \gamma \delta[18-20]$ in fetal muscle and $\alpha_{2} \beta \varepsilon \delta$ in adult muscle. Each subunit has 4 transmembrane segments (M1-M4)[21]. The M1-M3 are key structure for the ionchannel formation[22-24]. The extracellular domain, formed by the N-terminal 210 amino acids and followed by M1-M3 contains the acetylcholine (ACh) binding site[25, 26], which is formed at the interfaces between $\alpha$ and $\gamma$ or $\varepsilon$ subunits and between $\alpha$ and $\delta$ subunits [27, 28]. The intracellular domain forms a loop between M3 and M4. The homology between Torpedo and mammalian AChR is about $80 \%$ for the $\alpha$-subunits and $55 \%$ for the other subunits[2932 ], and the homology between equivalent subunits from mammalian species is $97 \%$ for $\alpha$-subunits and $90 \%$ for the other subunits[33]. Therefore, Torpedo and other electric rays and eels provide a rich source of AChR for characterization of receptor and for induction of an experimental autoimmune myasthenia gravis (EAMG) model of $\mathrm{MG}$ in mammals[7].

A characteristic feature of the AChR is the presence of a main immunogenic region (MIR) to which more than half of the autoantibodies in MG patients or EAMG rats are directed[34-37]. The MIR is located on the $\alpha$-subunit at residues 67-76[38-40], and its immunodominant epitopes are mainly formed by residues 68-71[41]. The MIR easily accessible in vivo to antibodies probably depends on its localization on extracellular surface and an unusual conformation[42]. The binding site of $\alpha$ - 
bungarotoxin $(\alpha-\mathrm{BT})$ is demonstrated at residues $189-199$ of $\alpha$-subunit[43, 44] which overlaps the ACh binding site.

\section{Experimental autoimmune myasthenia gravis}

The first experimental animal model of MG was discovered in 1973 by Patrick and Lindstrom in rabbits which were immunized with purified AChR from electric eel and developed muscle weakness[7]. EAMG, closely resembling MG in both immunological and clinical signs can be induced in mice[45], rats and guinea pigs[8], and monkeys[46] by active immunization of purified AChR or passive transfer of anti-AChR antibodies. In EAMG induced by injection of AChR incorporated in Complete Freund Adjuvant(CFA), animals develop clinical signs 4-6 weeks after immunization with peak of anti-AChR antibodies in sera[47]. AChR from different species of animals or synthetic and recombinant AChR[48-52] are able to induce EAMG. In EAMG induced by injection of anti-AChR antibodies[45, 53-55], animals develop similar clinical signs 12-48 h after injection[56].

\section{Pathogenesis in MG and EAMG}

Several lines of study have demonstrated that MG and EAMG are entirely mediated by antibody. Mice receiving repeated injection of $\mathrm{IgG}$ purified from $\mathrm{MG}$ patient sera develop EAMG[45, 57]. Mothers with MG can passively transfer MG to their babies[58, 59]. Treatment by plasmaphoresis to remove antibody is beneficial for MG patients[6062]. The AChR inactivation and degradation which impair signal transmission in the neuromuscular junction leading to muscle weakness are finally shared by a common pathway of antibody-mediated autoimmune attack to muscle AChR. The possible mechanisms in MG and EAMG are as follows.

1. Antigenic modulation. The binding of anti-AChR antibodies to AChR by crosslinking of adjacent AChR molecules resulting in accelerating AChR internalization is called antigenic modulation. Antibodies directed against the MIR are especially effective 
in modulating the AChR[63]. The MIR is angled outward from the central axis of the AChR. A single bivalent anti-MIR antibody can not cross-link the two $\alpha$-subunits within an AChR, however, it can position the cross-linking of adjacent AChR into aggregates[64], causing an increase in the rate of internalization and degeneration of AChR $[36,37,65]$. Antigenic modulation is independent of complement in vitro[65, 66].

2. Complement-mediated lysis. The binding of anti-AChR antibodies to AChR can also trigger the complement cascade, resulting in formation of membrane attack complex (MAC) which leads to focal lysis of postsynaptic membrane[55]. The severe muscular weakness or death seen in EAMG model of passive transfer of anti-AChR antibodies is likely caused by the fact that the effects of anti-AChR antibodies binding to AChR are amplified by $\mathrm{C} 3$ component of complement, which attracts phagocytes to mediate an antibody- and complement-dependent cell-mediated cytotoxic reaction[55, $67]$.

3. Inactivation of AChR. Less importantly, the binding of anti-AChR antibodies to AChR can block ACh from binding to $\mathrm{AChR}$ [68-72] or inhibit ion channel function[73].

\section{Immunological therapy}

The ideal immunosuppressive therapy for MG would be to eliminate the autoimmune response to AChR without affecting the immune response to other antigens. Unfortunately, no specific immunosuppressive therapy is currently applied in MG. Nonspecific immunosuppressive therapies such as immunosuppressants[74-77], thymectomy[78, 79] and plasmaphoresis [60-62, 80, 81] can control symptoms of MG and greatly reduce its mortality, however, side effects related to these therapeutic methods are also seen.

Several specific immunosuppressive therapies have been tested in EAMG based on the pathogenesis of MG. Anti-idiotypic antibodies to a mAb directed against AChR can prevent the induction of EAMG caused by the idiotype mAb[82]. Administration of AChR orally[83-85] or nasally[86-88] can suppress the immune response mediated by AChR specific T and B cells and prevent or inhibit clinical signs of EAMG. Since most 
of the antibodies to AChR in MG and EAMG are directed against MIR and thus pathogenic, development of a therapeutic agent which can bind to MIR, just blocking the binding of anti-MIR antibodies to AChR, but does not have the activities to induce antigenic modulation or complement reaction has been the focus of many researches in MG. Fab fragment or single chain variable fragment $(\mathrm{ScFv})$ of antibody are good candidates for this aim. Fab isolated from $M G$ patient thymus $[89,90]$ and from rat antiMIR mAbs[91, 92] or ScFv constructed from rat anti-MIR mAbs[37, 93, 94] can prevent anti-MIR mAbs or MG patient sera from binding to AChR or from inducing antigenic modulation in cultured TE671 cell line.

\section{Mouse EAMG induced by human anti-AChR antibodies}

The importance of human immunoglobulins in the pathogenesis of MG was first demonstrated in mice, which developed clinical signs of MG upon multiple injections of MG serum, by Toyka et al in 1975[45]. Another earlier study, in which MG patient thymus tissue or its single-cell suspensions was transplanted into severe combined immunodeficiency (SCID) mice, showed that human anti-AChR antibodies were produced in mouse sera, and also found at muscle end-plates, but no clinical signs of muscular weakness were observed[95]. This model was used to determine the role of Thelper cells in the pathogenesis of MG[96]. Mice have strain-dependent susceptibilities to EAMG, although anti-AChR antibody titers in sera and fine specificities are comparable[97, 98]. Mice transgenic for different HLA genes also have different susceptibilities to EAMG[99]. Since the mice transgenic for human immunoglobulin loci were established[100], it is possible to develop a new transgenic mouse EAMG model. The use of human genes and molecules in animal EAMG clearly matches the model more closely to MG. 


\section{Aim of the study}

One of the key questions in understanding the pathogenesis of MG and EAMG induced by pathogenic anti-AChR autoantibodies is the antibody structure, which will be beneficial to the development of a potentially specific therapy for MG. Therefore, the first part of this thesis (Chapter 1 to Chapter 3) was focussed on the production and characterization of anti-AChR mAbs made from mice immunized with AChR, and the nucleotide and amino acid sequences of variable regions of the mAbs in relation with their pathogenicity and specificity. The second part of this thesis (Chapter 4) was concentrated on the construction and characterization of an human $\mathrm{ScFv}$ derived from an anti-MIR autoantibody isolated from a MG patient. The ScFv might be useful in specific immunotherapy of MG after appropriate genetic improvement in stability and affinity based on the understanding of antibody structure described in Chapter 2 and Chapter 3 . The third part of this thesis (Chapter 5) was emphasized on the development of a new transgenic mouse EAMG model producing human immunoglobulins. This model is expected to be the first step towards an ideal EAMG model of mice transgenic for human immunoglobulin and HLA loci, and a source of human anti-AChR antibodies.

\section{References}

1 Lindstrom J, Shelton D, Fujii Y. Myasthenia gravis. Adv Immunol, 1988, 42: 233-284

2 Graus Y, de Baets M. Myasthenia gravis: an autoimmune response against the acetylcholine receptor. Immunol Res, 1993, 12: 78-100

3 Oosterhuis H. Historical introduction. In: De Baets M, Oosterhuis H eds. Myasthenia Gravis, Boca Raton: CRC Press, 1993

4 Simpson J. Myasthenia gravis: a new hypothesis. Scottish Med J, 1960, 5: 419-437

5 Nastuk W, Strauss A, Osserman K. Search for a neuromuscular blocking agent in the blood of patients with myasthenia gravis. Am J Med, 1959, 26: 394-409

6 Nastuk W, Plescia O, Osserman K. Changes in the serum complement activity in patients with myasthenia gravis. Proc Soc Exp Bio Med, 1960, 105: 177-184 
7 Patrick J, Lindstrom J. Autoimmune response to acetylcholine receptor. Science, 1973, 180: $871-872$

8 Lennon V, Lindstrom J, Seybold M. Experimental autoimmune myasthenia: a model of myasthenia gravis in rats and guinea pigs. J Exp Med, 1975, 141: 1365-1375

9 Drachman B. Myasthenia gravis. N Eng J Med, 1994, 330: 1797-1810

10 Vincent A, Li Z, Hart A, Barrett-Jolley R, Yamamoto T, Burges J, Wray D, Byrne N, Molenaar P, Newsom-Davis J. Seronegative myasthenia gravis. Evidence for plasma factor(s) interfering with acetylcholine receptor function. Ann NY Acad Sci, 1993, 681: $529-538$

11 Oosterhuis HJGH. Myasthenia gravis. In: Clinical Neurology and Neurosurgery monographs vol 5, Glaser GH Ed, Churchill Livingstone. Edinburgh

12 Kao I, Drachman DB. Thymic muscle cells bear acetylcholine receptors: possible relation to myasthenia gravis. Science, $1977,195: 74-75$

13 Schluep M, Willcox NH, Vincent A, Dhoot GK, Newsom-Davis J. Acetylcholine receptors in human myoid cells in situ: an immunohistochemical study. Ann Neurol, 1987, 22: 212-222

14 Kirchner T, Hoppe F, Schalke B, Muller-Hermelink HK. Microenvironment of thymic myoid cells in myasthenia gravis. Virch Archiv B cell Pathol, 1988, 54: 395 402

15 Melms A, Schalke BCG, Kirchner T, Muller-Hermelink HK, Albert E, Wekerle H. Thymus in myasthenia gravis: isolation of T-lymphocyte lines specific for the nicotinic acetylcholine receptor from the thymuses of myasthenia gravis patients. $J$ Clin Invest, 1988, 81: 902-908

16 Oosterhuis H. Clinical aspects. In: De Baets M, Oosterhuis H eds. Myasthenia gravis, Boca Raton: CRC Press, 1993

17 Drachman D. Immunotherapy in neuromuscular disorders: current and future strategies. Muscle Nerve, 1996, 19: 1239-1251

18 Lindstrom J, Merlie J, Yogeeswaran G. Biochemical properties of acetylcholine receptor subunits from Torpedo californica. Biochemistry, 1979, 18: 4465-4470

19 Raftery MA, Hunskappiler MW, Stradler CD, Hood LE. acetylcholine receptor: complex of homologous subunits. Science, 1980, 208: 1454-1457 
20 Kubalek E, Ralston S, Lindstrom J, Unwin N. Localization of subunits within the acetylcholine receptor by electron image analysis of tubular crystals from Torpedo marmorata. J Cell Biol, 1987, 105: 9-18

21 Stroud R, McCarty M, Shuster M. Nicotinic acetylcholine receptor superfamily of ligand-gated ion channels. Biochemistry, 1990, 29: 11009-11023

22 Imoto K, Methfessel C, Sakmann B, Mishina M, Mori Y, Konno T, Fukuda K, Kurasaki M, Bujo H, Fujita Y. Location of a $\delta$-subunit region determining ion transport through the acetylcholine receptor channel. Nature, 1986, 324: 670-674

23 Imoto K, Busch C, Sakmann B, Mishina M, Konno T, Nakai J, Bujo H, Mori Y, Fukuda K, Numa S. Rings of negatively charged amino acids determine the acetylcholine receptor channel conductance. Nature, 1988, 335: 645-648

24 Leonard R, Labarca C, Charnet P, Davidson N, Lester HA. Evidence that the M2 membrane-spanning region lines the ion channel pore of the nicotinic receptor. Science, 1988: 242: 1578-1581

25 Kao P, Dwork A, Kaldany R, Silver M, Wideman J, Stein S, Karlin A. Identification of the subunit half cysteine specifically labeled by an affinity reagent for the acetylcholine receptor binding site. J Biol Chem, 1984, 259: 11662-11665

26 Kao P, Karlin A. Acetylcholine receptor binding site contains a disulfide cross-link between adjacent half-cysteinyl residues. J Biol Chem, 1986, 261: 8085-8088

27 Karlin A, Akabas M. Toward a structural basis of the function of nicotinic acetylcholine receptors and their cousins. Neuron, 1995, 15: 1231-1244

28 Kreienkamp HJ, Maeda R, Sine S, Taylor P. Inter-subunit contacts governing assembly of the mammalian nicotinic acetylcholine receptor. Neuron, 1995, 14: 635644

29 Noda M, Furutani Y, Takahashi H, Toyosato M, Tanabe T, Shimizu S, Kidyotani S, KayanoT, Hirose T, Inayama S, Numa S. Cloning and sequence analysis of calf cDNA encoding $\alpha$-subunit precursor of muscle acetylcholine receptor. Nature, 1983, 305: $818-823$

30 Tanabe T, Noda M, Furutani Y, Takai T, Takahashi H, Tanaka K, Hirose T, Inayama S, Numa S. Primary structure of $\beta$ subunit precursor of calf muscle acetylcholine receptor deduced form cDNA sequence. Eur J Biochem, 1984, 144: 11-17 
31 Takai T, Noda M, Furutani Y, Takahashi H, Notake M, Shimizu S, KayanoT, Tanabe T, Tanaka K, Hirose T, Inayama S, Numa S. Primary structure of $\gamma$ subunit precursor of calf-muscle acetylcholine receptor deduced from the cDNA sequence. Eur $J$ Biochem, 1984, 143: 109-115

32 Kubo T, Noda M, Takai T, Tanabe T, Kayana T, Shimizu S, Tanaka K, Takahashi H, Hirose T, Inayama S, Kikuno R, Miyata T, Numa S. Primary structure of $\delta$ subunit precursor of calf muscle acetylcholine receptor deduced from cDNA sequence. Eur $J$ Biochem, 1984, 149: 5-13

33 Beeson D, Barnard E. Acetylcholine receptors at the neuromuscular junction. In: Vincent A, Wray D eds. Neuromuscular Transmission. basic and applied aspects. Manchester University Press, 1990

34 Tzartos SJ, Lindstrom JM. Monoclonal antibodies used to probe acetylcholine receptor structure: localization of the main immunogenic region and detection of similarities between subunits. Proc Natl Acad Sci USA, 1980, 77: 755-759

35 Tzartos SJ, Seybold ME, Lindstrom JM. Specificities of antibodies to acetylcholine receptors in sera from myasthenia gravis patients measured by monoclonal antibodies. Proc Natl Acad Sci USA, 1982, 79: 188-192

36 Tzartos S, Barkas T, Cung M, Mamalaki A, Marraud M, Papanastasiou D, Sakarellos C, Sakarellos-Daitsiotis M, Tsantili P, Tsikaris V. Anatomy of the antigenic structure of a large membrane autoantigen, the muscle-type nicotinic acetylcholine receptor. Immunol Rev, 1998, 163: 89-120

37 Papanastasiou D, Mamalaki A, Eliopoulos E, Poulas K, Liolitsas C, Tzartos S. Construction and characterization of a humanized single chain Fv antibody fragment against the main immunogenic region of the acetylcholine receptor. J Neuroimmunol, 1999, 94: 182-185

38 Barkas T, Mauron A, Roth B, Alliod C, Tzartos S, Ballivet M. Mapping of the main immunogenic region and toxin binding site of the nicotinic acetylcholine receptor. Science, 1987, 235: 77-80

39 Barkas T, Gabriel J-M, Mauron A, Hughes G, Roth B, Alliod C, Tzartos S, Ballivet M. Monoclonal antibodies to the main immunogenic region of the nicotinic acetylcholine receptor binds to residues 61-76 of the $\alpha$-subunit. J Biol Chem, 1988, 263: $5916-5920$ 
40 Tzartos SJ, Kokla A, Walgrave S, Conti-Tronconi B. Localization of the main immunogenic region of the human muscle acetylcholine receptor to residues 67-76 of the $\alpha$-subunit. Proc Natl Acad Sci USA, 1988, 85: 2899-2903

41 Tzartos SJ, Loutrari HV, Tang F, Kokla A, Walgrave SL, Milius RP, Conti-Tronconi B. Main immunogenic region of Torpedo electroplax and human acetylcholine receptor : localization and microheterogeneity revealed by the use of synthetic peptides. J Neurochem, 1990, 54: 51-61

42 Beroukhim R, Unwin N. Three-dimensional location of the main immunogenic region of the acetylcholine receptor. Neuron, 1995, 15: 323-331

43 Tzartos SJ, Remoundos MS. Fine localization of the major $\alpha$-bungarotoxin binding site to residues $\alpha$ 185-195 of the acetylcholine receptor. Residues 189, 190, and 195 are indispensable for binding. J Biol Chem, 1990, 265: 21462-21467

44 Griesmann GE, McCormick DJ, De Aizpurua HJ, Lennon VA. $\alpha$-bungarotoxin binding to human acetylcholine receptor $\alpha$-subunit peptide 185-199 in solution and solid phase but not to peptide 125-147 and 389-409. J Neurochem, 1990, 54: 15411547

45 Toyka KV, Drachman DB, Pestronk A, Kao I. Myasthenia gravis: Passive transfer from man to mouse. Science, 1975, 190: 397-399

46 Tarrab-Hazdai R, Aharonov A, Silverman I, Fuchs S, Abramsky O. Experimental autoimmune myasthenia gravis induced in monkeys by purified acetylcholine receptor. Nature, 1975, 256: 128-130

47 Lindstrom J. Autoimmune response to acetylcholine receptor in myasthenia gravis and its animal model. Adv Immunol, 1979, 27: 1-50

48 Lindstrom JM, Einarson BL, Lennon VA, Seybold ME. Pathological mechanisms in experimental autoimmune myasthenia gravis. I. Immunogenicity of syngeneic acetylcholine receptor and quantitative extraction of receptor and antibody-receptor complexes from muscles of rats with experimental autoimmune myasthenia gravis. $J$ Exp Med, 1976, 144: 726-738

49 Einarson B, Gullick W, Conti-Tronconi B, Ellisman M, Lindstrom J. Subunit composition of bovine muscle acetylcholine receptor. Biochemistry, 1982, 21: 52955302 
50 Lennon VA, Griesmann GA, McCormick DJ, Huang Z-X, Feng H, Lambert EH. Definition of myasthenogenic sites of the human acetylcholine receptor using synthetic peptides. Ann NY Acad Sci, 1987, 505: 439-450

51 McCormick DJ, Griesmann GA, Huang Z-X, Lambert EH. Lennon VA. Myasthenogenicity of human acetylcholine receptor synthetic $\alpha$ subunit peptide 125147 does not require intramolecular disulphide cyclization. J Immonol, 1987, 139: 2615-2619

52 Lennon VA, Lambert EH, Leiby KR, Okarma TB, Talib S. Recombinant human acetylcholine receptor $\alpha$-subunit induces chronic experimental autoimmune myasthenia gravis. J Immunol, 1991, 146: 2245-2248

53 Richman DP, Gomez CM, Berman PW, Burres SA, Fitch FW, Arnason BG. Monoclonal anti-acetylcholine receptor antibodies can cause experimental myasthenia. Nature, 1980, 286: 738-739

54 Gomez CM, Richman DP. Monoclonal anti-acetylcholine receptor antibodies with differing capacities to induce experimental autoimmune myasthenia gravis. $J$ Immunol, 1983, 135: 234-241

55 Tzartos SJ, Hochschwender S, Vasquez P, Lindstrom J. Passive transfer of experimental autoimmune myasthenia gravis by monoclonal antibodies to the main immunogenic region of the acetylcholine receptor. J Neuroimmunol, 1987, 15: 185194

56 Gomez CM, Wollman RL, Richman DP. Induction of morphologic changes of both acute and chronic experimental myasthenia by monoclonal antibody directed against acetylcholine receptor. Acta Neuropathol, 1984, 63: 131-143

57 Toyka KV, Birmberger KL, Anzil AP, Schlegel C, Besinger V, Struppler A. Myasthenia gravis: further electrophsilogical and ultrastructural analysis of transmission failure in the mouse passive transfer model. J Neurol Neurosurg Psychiatry, 1978, 41: 746-753

58 Keesey J, Lindstrom J, Cokely A. Anti-acetylcholine receptor antibody in neonatal myasthenia gravis. $N$ Eng $J$ Med, 1977, 296: 55

59 Vernet-der Garabedian B, Lacokova M, Eymard B, Morel E, Faltin M, Zajac J, Sadovsky O, Dommergues M, Tripon P, Bach JF. Association of neonatal myasthenia 
gravis with antibodies against the fetal acetylcholine receptor. J Clin Invest. 1994, 94: $555-559$

60 Pinching AJ, Peters DK, Newsom-Davis J. Remmission of myasthenia gravis following plasma exchange. Lancet, 1976, 11: 1373-1376

61 Dau PC, Lindstrom JM, Cassel CK, Denys EH, Shev EE, Spitler LE. Plasmaphoresis and immunosuppressive drug therapy in myasthenia gravis. $N$ Eng $J$ Med, 1977, 297: $1134-1140$

62 Newsom-Davis J, Pinching AJ, Vincent A, Willson SG. Function of circulating antibody to acetylcholine-receptor in myasthenia gravis investigated by plasma exchange. Neurology, 1978, 28: 266-272

63 Tzartos SJ, Starzinski-Powitz A. Decrease in acetylcholine-receptor content of human myotube cultures mediated by monoclonal antibodies to $\alpha, \beta$ and $\gamma$ subunits. FEBS Lett. 1986, 196: 91-95

64 Conti-Tronconi B, Tzartos S, Lindstrom J. Monoclonal antibodies as probes of acetylcholine receptor structure. II. Binding to native receptor. Biochemistry, 1981, 20: $2181-2191$

65 Heinemann S, Bevan S, Kullberg R, Lindstrom J, Rice J. Modulation of the acetylcholine receptor by anti-receptor antibody. Proc Natl Acad Sci USA, 1977, 74: 3090-3094

66 Appel SH, Anwyl R, McAdams MW, Elias S. Accelerated degradation of acetylcholine receptor from cultured rat myotubes with myasthenia gravis sera and globulins. Proc Natl Acad Sci USA, 1977, 74: 2130-2134

67 Lindstrom J, Engel A, Seybold M, Lennon V, Lambert E. Pathological mechanisms in EAMG. II: Passive transfer of experimental autoimmune myasthenia gravis in rats with anti-acetylcholine receptor antibodies. J Exp Med, 1976, 144: 739-753

68 Gomez CM, Richman DP, Berman PW, Burries SA, Arnason BGW, Fitch FW. Monoclonal antibodies against purified nicotinic acetylcholine receptor. Biochem Biophys Res Commun, 1979, 88: 575-582

69 Watters D, Maelicke A. Organization of ligand binding sites at the acetylcholine receptor: A study with monoclonal antibodies. Biochemistry, 1983, 22: 1811-1819 
70 Cleveland WL, Wasserman NH, Sarangarajan R, Penn AS, Erlanger BF. Monoclonal antibodies to the acetylcholine receptor by a normally functioning auto-anti-idiotypic mechanism. Nature, 1983, 305: 56-57

71 Whiting P, Vincent A, Newsom-Davis J. Monoclonal antibodies to Torpedo acetylcholine receptor. Characterization of antigenic determinants within the cholinergic binding site. Eur J Biochem, 1985, 150: 533-539

72 Dowding AJ, Hall ZM. Monoclonal antibodies specific for each of the two toxinbinding sites of Torpedo acetylcholine receptor. Biochemistry, 1987, 26: 6372-6381

73 Donnelly A, Mihovilovic M, Gonzalez-Ros JM, Ferragut JA, Richman D, MartinezCarrion M. Noncholinergic site-directed monoclonal antibody can impair agonistinduced ion flux ion Torpedo californica acetylcholine receptor. Proc Natl Acad Sci USA, 1984, 81: 7999-8003

74 Seybold M, Drachman D. Gradually increasing doses of prednison in myasthenia gravis. $N$ Eng J Med, 1974, 290: 81-84

75 Abramsky O, Aharonow A, Teitelbaum D, Fuchs S. Myasthenia gravis and acetylcholine receptor. Effect of steroids in clinical course and cellular immune response to acetylcholine receptor. Arch Neurol, 1975, 32: 684-687

76 Matell G. Immunosuppressive drugs: azathioprine in the treatment of myasthenia gravis. Ann NY Acad Sci, 1987, 505: 588-594

77 Kaplan I, Blakely B, Pavlath G, Travis M, Blau H. Steroids induce acetylcholine receptors on cultured human muscle: implication for myasthenia gravis. Proc Natl Acad Sci USA, 1990, 87: 8101-8104

78 Vincent A, Newsom-Davis J, Newton P, Beck N. Acetylcholine receptor antibody and clinical response to thymectomy in myasthenia gravis. Neurology, 1983, 33: 1276-1282

79 Kuks J, Oosterhuis H, Limburg P, The T. Anti-acetylcholine receptor antibodies decrease after thymectomy in patients with myasthenia gravis. Clinical correlations. $J$ Autoimmun, 1991, 4: 197-211

80 Samtleben W, Besinger U, Toyka K, Fateh-Moghadam A, Brehm G, Gurland H. Plasma-separation in myasthenia gravis: a new method of rapid plasma exchange. Klin Wochenschr, 1980, 58: 47-49 
81 Nielsen V, Paulson O, Rosenkvist J, Holsoe E, Lefwert A.Rapid improvement of myasthenia gravis after plasma exchange. Ann Neurol, 1982, 11: 160-169

82 Souroujon M, Pachner A, Fuchs S. The treatment of passively transferred experimental myasthenia with anti-idiotypic antibodies. Neurology, 1986, 36: 622625

83 Wang Z-Y, Qiao J, Link H. Suppression of experimental autoimmune myasthenia gravis by oral administration of acetylcholine receptor. J Neuroimmunol, 1993, 44: 209-214

84 Wang Z-Y, Qiao J, Melms A, Link H. T cell reactivity to acetylcholine receptor in rats orally tolerized against experimental autoimmune myasthenia gravis. Cell Immunol, 1993, 152: 394-404

85 Wang Z-Y, Huang J, Olsson T, He B, Link H. B cell responses to acetylcholine receptor in rats orally tolerized against experimental autoimmune myasthenia gravis. J Neurol Sci, 1995, 128: 167-174

86 Karachunski P, Ostlie N, Okita D, Conti-Fine B. Prevention of experimental myasthenia gravis by nasal administration of synthetic acetylcholine receptor $\mathrm{T}$ epitope sequences. J Clin Invest, 1997, 100: 3027-3035

87 Barchan D, Sourojon M, Im S-H, Antozzi C, Fuchs S. Antigen specific modulation of experimental myasthenia gravis: nasal tolerization with recombinant fragments of the human acetylcholine receptor $\alpha$ subunit. Proc Natl Acad Sci USA, 1999, 96: 80868091

88 Shi FD, Li H, Wang H, Bai X, Van de Meide P, Link H, Ljunggren HG. Mechanisms of nasal tolerance induction in experimental autoimmune myasthenia gravis: identification of regulatory cells. J Immunol, 1999, 162, 5757-5763

89 Graus Y, de Baets M, Parren P, Berrih-Aknin S, Wokke J, van Breda Vriesman P, Burton D. Human anti-nicotinic acetylcholine receptor recombinant Fab fragments isolated from thymus-derived phage display libraries from myasthenia gravis patients reflect predominant specificities in serum and block the action of pathogenic serum antibodies. J Immunol, 1997, 158: 1919-1929

90 Farrar J, Portolano S, Willcox N, Vincent A, Jacobson L, Newsom-Davis J, Rapoport B, McLachlan SM. Diverse Fab specific for acetylcholine receptor epitopes from a myasthenia gravis thymus combinatoral library. Int Immunol, 1997, 9: 1311-1318 
91 Sophianos D, Tzartos S. Fab fragments of monoclonal antibodies protect the human acetylcholine receptor against degradation caused by myasthenic sera. $J$ Autoimmun, 1989, 2: 779-789

92 Papanastasiou D, Poulas K, Kokla A, Tzartos SJ. Prevention of passively transferred experimental autoimmune myasthenia gravis by Fab fragments of monoclonal antibodies directed against the main immunogenic region of the acetylcholine receptor. J Neuroimmunol, 2000, 104: 124-132

93 Mamalaki A, Trakas N, Tzartos SJ. Bacterial expression of single-chain Fv fragment which efficiently protects the acetylcholine receptor against antigenic modulation caused by myasthenic antibodies. Eur J Immunol, 1993, 23: 1839-1845

94 Tsantili P, Tzartos SJ, Mamalaki A. High affinity single-chain antibody fragments protecting the human nicotinic acetylcholine receptor. J Neuroimmunol, 1999, 94: 1527

95 Schönbeck S, Padberg F, Hohlfeld R, Wekerle H. Transplantation of thymic autoimmune microenvironment to severe combined immunodeficiency mice. J Clin Invest, 1992, 90: 245-250

96 Aissaoui A, Klingel-Schmitt I, Couderc J, Chateau D, Romagne F, Jambou F, Vincent A, Levasseur P, Eymard B, Maillot MC, Galanaud P, Berrih-Aknin S, CohenKaminsky S. Prevention of autoimmune attack by targeting specific T-cell receptors in a severe combined immunodeficiency mouse model of myasthenia gravis. Ann Neurol, 1999, 46: 559-567

97 Berman PW, Patrick J. Experimental myasthenia gravis. A murine system. $J$ Exp Med, 1980, 151: 204-223

98 Graus YM, van Breda Vriesman PJ, de Baets MH. Characterization of antiacetylcholine receptor (AChR) antibodies from mice differing in susceptibility for experimental autoimmune myasthenia gravis (EAMG). Clin Exp Immunol, 1993, 92: 506-513

99 Raju R, Zhan W-Z, Karachunski P, Conti-Fine B, Sieck GC, David C. Polymorphism at the HLA-DQ locus determines susceptibility to experimental myasthenia gravis. $J$ Immunol, 1998, 160: 4169-4174 
100 Lonberg N, Taylo LD, Harding FA, Trounstine M, Higgins KM, Schramm SR, Kuo C-C, Mashayekh R, Wymore K, McCabe JG, Munoz-O'Regan D, O’Donnell SL, Lapachet ESG, Bengoechea T, Fishwild DM, Carmack CE, Kay RM, Huszar D. Antigen-specific human antibodies from mice comprising four distinct genetic modifications. Nature, 1994, 368: 856-859 


\title{
Chapter 1
}

\section{Production and characteristics of anti-acetylcholine receptor monoclonal antibodies in mice}

\begin{abstract}
A mouse model of myasthenia gravis (MG), experimental autoimmune myasthenia gravis (EAMG), was used to produce monoclonal antibodies (mAbs) directed against the autoantigen, acetylcholine receptor (AChR). C57bl/6 and Balb/c mice were immunized with purified Torpedo AChR (tAChR) and human AChR (hAChR), and boosted 3 and 5 weeks after primary immunization. The mice were sacrificed 3 days after the last injection and cells from lymphnodes were fused with mouse myeloma cell line SP2/OAg14 or NS1. Hybridomas were initially screened for reactivity to AChR by ELISA. Most of the anti-AChR mAbs were found to be $\operatorname{IgG1}$ and $\operatorname{IgG} 2 \mathrm{~b}$ as determined by a mouse isotyping kit, and some of them were cross-reactive with mouse and rat AChR as showed in radioimmunoassay (RIA) using mouse and rat muscle crude extracts as antigens. Determination of fine specificity of the anti-AChR mAbs binding to AChR using competitive ELISA or RIA showed that four different groups of the mAbs were identified: anti-main immunogenic region (MIR) mAbs (rat anti-MIR mAbs 35 as reference competitor), anti- $\alpha$-bungarotoxin ( $\alpha$-BT) binding site mAbs $(\alpha-\mathrm{BT}$ as reference competitor), anti-extracellular epitope mAbs and anti-intracellular epitope mAbs
\end{abstract}




\section{Introduction}

Myasthenia gravis (MG) is an autoimmune disease mediated by autoantibodies directed against acetylcholine receptor (AChR)[1]. Anti-AChR antibodies binding to AChR on postsynaptic membrane in neuromuscular junction result in AChR loss either by crosslinking of adjacent receptor molecules thereby accelerating the AChR turnover rate[2,3] or by activation of complement cascade leading to focal lysis of the muscle membrane[4,5]. The binding of anti-AChR antibodies may also result in functional inactivation of the AChR by either interfering with acetylcholine binding[6-10] or inhibiting ion channel function[11]. The animal model of MG, experimental autoimmune myasthenia gravis (EAMG), closely resembling human MG in both immunological and clinical signs, can be induced by active immunization with purified AChR or passive transfer of anti-AChR antibodies[12,13].

The AChR is a well characterized autoantigen[14]. The pathogenic antibodies are mainly found to be those that are directed against a region on the $\alpha$-subunit of AChR, which includes the amino acid sequence 67-76, termed main immunogenic region (MIR)[15]. However, blocking antibodies have been demonstrated in sera of MG patients by inhibition of $\alpha$-bungarotoxin ( $\alpha$-BT) binding to AChR in muscle culture or TE671 cells[16,17]. Therefore, the contribution of individual pathogenic anti-AChR antibodies to $\mathrm{AChR}$ loss or inhibition of $\mathrm{AChR}$ function is important for understanding the pathogenesis of MG or EAMG.

The anti-Torpedo AChR (tAChR) monoclonal antibodies (mAbs) were originally produced by Dr Y. Graus et al[18], and anti-human AChR (hAChR) mAbs by Dr P. Whiting et al[19]. Since this work formed the basis of the research in Chapter 2 and 3, we describe here the main techniques used in production and characterization of the mAbs in order to further investigate the pathogenicity of mAbs in relation to their structure. 


\section{Materials and methods}

Animals

$\mathrm{C} 57 \mathrm{bl} / 6$ and Balb/c mice of 8 weeks old (about $20 \mathrm{~g}$ body weight) were purchased from Charles River Wiga GmbH, Frankfurt, Germany and maintained under special pathogen free conditions.

Antigens

TAChR, extracted from electric organ of Torpedo californica (Pacific Biomarine, California, USA) and purified by affinity chromatography on Naja naja siamensis toxin (Miami Serpentarium, Florida, USA) linked to Sepharose-4B (Pharmacia LKB, Woerden, The Netherlands) according to a procedure described by Lindstrom et al[20], and hAChR, obtained from amputated limbs of a patient without vascular or neurological disease and purified as above, were used as antigens to immunize mice.

\section{Production of hybridomas}

Mice were hypodermically immunized with $15 \mu \mathrm{g}$ tAChR (diluted with PBS) in Complete Freund Adjuvant (CFA) at base of the tail, and boosted 3 and 5 weeks after primary immunization with $15 \mu \mathrm{g}$ tAChR in Incomplete Freund Adjuvant (IFA). The mice were sacrificed 3 days after the last injection. Lymphocytes from lymphnodes paraaortal, inguinal and poplitial were fused with the mouse myeloma cell line SP2/OAg14 according to Kohler and Milstein[21]. For the production of anti-hAChR mAbs, 12 pmol hAChR in CFA was used in primary immunization, 16 pmol hAChR in IFA in the first booster immunization and 40 pmol hAChR in PBS only in the second booster immunization. The fusion was performed with mouse myeloma cell line NS1. 
Screening of $m A b s$

MAbs were initially screened for reactivity to tAChR by ELISA. Briefly, ELISA plates were coated with $5 \mu \mathrm{g} / \mathrm{ml}$ tAChR in $10 \mathrm{mM}$ sodium bicarbonate buffer ( $\mathrm{pH} 9.5$ ) for $1 \mathrm{~h}$ at $37^{\circ} \mathrm{C}(50 \mu \mathrm{l} /$ well). The plates, after washed 3 times with distilled water containing $0.5 \%$ Tween-20 $\left(\mathrm{dH}_{2} \mathrm{O} / \mathrm{Tw}\right)$, were blocked with PBS containing $0.5 \%$ bovine serum albumin (BSA) and $0.5 \%$ Tween-20 for $15 \mathrm{~min}$ at room temperature. Hybridoma culture supernatant $(100 \mu \mathrm{l})$ were added to each well and the plates were incubated at $4{ }^{\circ} \mathrm{C}$ overnight on a rocking platform. After washing 5 times with $\mathrm{dH}_{2} \mathrm{O} / \mathrm{Tw}$, the plates were incubated with rabbit anti-mouse immunoglobulin coupled with horseradish peroxidase (HRP) (Dako ITK diagnostics, Uithoorn, The Netherlands) for $1 \mathrm{~h}$ at room temperature on a rocker. After washing the colormetric reaction was developed for $10 \mathrm{~min}$ at room temperature by addition of substrate solution of tetramethylbenzidine (TMB) (100 $\mu \mathrm{g} / \mathrm{ml}$ TMB, $0.01 \% \mathrm{H}_{2} \mathrm{O}_{2}, 110 \mathrm{mM}$ sodium acetate, $\mathrm{pH} 5.5$ ) and stopped by adding $50 \mu \mathrm{l}$ of $2 \mathrm{M}$ $\mathrm{H}_{2} \mathrm{SO}_{4}$. The optical density (OD) of individual wells was measured at $450 \mathrm{~nm}$ using Titertek Twinreader (Amstelstad, Amsterdam, The Netherlands).

Cell lines secreting anti-hAChR mAbs were determined by radioimmunoassay (RIA) as described below using hAChR.

Isotype of $m A b s$

The isotypes of mAbs were determined by an ELISA using a mouse isotyping kit (Holland Biotechnology, Leiden, The Netherlands) according to the manufacturer's instructions.

Fine specificity of anti-AChR $m A b s$

MAbs were screened for reactivity to the MIR on AChR by a competitive inhibition ELISA using mAb 35[22] ( a kind gift of Dr S. J. Tzartos, Institute Pasteur Hellenique, Athens, Greece) as a reference anti-MIR antibody. Briefly, 96-well ELISA plates were coated with $50 \mu \mathrm{l}$ of $5 \mu \mathrm{g} / \mathrm{ml}$ purified tAChR as above and incubated for $1 \mathrm{~h}$ at $37^{\circ} \mathrm{C}$ with 
$50 \mu \mathrm{l}$ of protein $\mathrm{G}$ purified anti-AChR mAb with increasing concentration (0.001-10 $\mu \mathrm{g} / \mathrm{ml})$. Subsequently, plates were incubated for $1 \mathrm{~h}$ at $37^{\circ} \mathrm{C}$ with $50 \mu \mathrm{l}$ of $\mathrm{mAb} 35$ coupled with $\mathrm{HRP}(0.04 \mu \mathrm{g} / \mathrm{ml}, 50 \%$ of maximum binding to AChR predetermined $)$. The colormetric reaction was developed as described above. The results are expressed as percentage inhibition of mAb 35-HRP binding to AChR and calculated as follows: [(average $\mathrm{OD}_{450}$ of duplicate wells with $\mathrm{mAb} 35-\mathrm{HRP}$ alone - average $\mathrm{OD}_{450}$ of duplicate wells in which mAb 35-HRP was tested in the presence of anti-AChR mAb) / average $\mathrm{OD}_{450}$ of duplicate wells with $\mathrm{mAb} 35$-HRP alone] x 100. The mAbs with more than $50 \%$ inhibition of mAb 35-HRP to AChR were considered as anti-MIR antibodies[23].

MAbs were also tested for their ability to inhibit the binding of ${ }^{125} \mathrm{I}-\alpha-\mathrm{BT}$ to AChR by an assay as follows: ELISA plates were coated with $50 \mu \mathrm{l}$ of $5 \mu \mathrm{g} / \mathrm{ml}$ purified tAChR as described above and incubated with $100 \mu$ of hybridoma supernatant at room temperature overnight. The supernatant was removed by aspiration and plates were subsequently incubated with a limiting concentration of ${ }^{125} \mathrm{I}-\alpha-\mathrm{BT}(2 \mathrm{pmol} / \mathrm{ml})$ for $2 \mathrm{~h}$ at room temperature. Plates were washed and radioactivity was counted in a gamma counter. The results are expressed as percentage inhibition of ${ }^{125} \mathrm{I}-\alpha$-BT binding to AChR and calculated as follows: [(average cpm of duplicate wells with ${ }^{125} \mathrm{I}-\alpha-\mathrm{BT}$ alone average cpm of duplicate wells with ${ }^{125} \mathrm{I}-\alpha-\mathrm{BT}$ in the presence of anti-AChR mAb) / average cpm of duplicate wells with ${ }^{125} \mathrm{I}-\alpha$-BT alone] x 100.

MAbs were also investigated for binding to extracellular and intracellular epitopes on AChR rich memberane vesicles. ELISA plates were coated with purified mAb (25 $\mu \mathrm{g} / \mathrm{ml}$ ) for $1 \mathrm{~h}$ at $37{ }^{\circ} \mathrm{C}$, and subsequently incubated with $150 \mu \mathrm{l}$ AChR rich memberane vesicles ( $80 \mathrm{fmol} \mathrm{AChR}$ ), isolated from electric organ of Torpedo californica as previously described[20], labeled with ${ }^{125} \mathrm{I}-\alpha-\mathrm{BT}$ at $4{ }^{\circ} \mathrm{C}$ overnight. After washing the bound radioactivity was counted as above.

MAbs which failed to inhibit the binding of mAb 35 to MIR or binding of ${ }^{125} \mathrm{I}-\alpha-$ BT to AChR but were directed against the extracellular epitopes were further determined for recognizing subunits of AChR by Western blotting. Subunits of AChR were separated by SDS-PAGE and transferred onto nitrocellulose filter. The binding of mAbs to subunits was visualized by adding rabbit anti-mouse immunoglobulin coupled with HRP and 
substrate diaminobenzidine tetrahydrochloride (DAB). The molecular weight standard was stained with ponceau[24].

Cross-reaction with mouse, rat and human AChR

MAbs were tested for cross-reactivity to mouse $\mathrm{AChR}$ (mAChR), rat AChR (rAChR) and hAChR by RIA. Briefly, $200 \mu \mathrm{l}$ of mAChR (isolated from mouse muscle) or rAChR (isolated from rat muscle) or hAChR extracts were labeled with ${ }^{125} \mathrm{I}-\alpha$-BT ( 2 pmol ${ }^{125} \mathrm{I}-\alpha-$ BT / pmol AChR) for $4 \mathrm{~h}$ at $4^{\circ} \mathrm{C}$, and subsequently incubated with $200 \mu$ l hybridoma culture supernatant at $4^{\circ} \mathrm{C}$ overnight. The complex of $\mathrm{mAbs}$ and $\mathrm{AChR}$ were precipitated by adding rabbit anti-mouse immunoglobulin and bound radioactivity was counted as described above.

\section{Passive transfer of anti-AChR $m A b s$}

The potential of anti-MIR mAbs to induce clinical signs of EAMG was determined by passive transfer of anti-MIR mAbs to 8-10 week-old female Lewis rats (for mAbs A7, A24, A42, A43, D6 and G10) or 8 week-old female C57bl/6 mice (for mAb A60)[24]. Passive transfer EAMG was induced by i. p. injection of 20 fold concentrated culture supernatant of anti-MIR mAbs in final volume of $5 \mathrm{ml}$. Control rats were injected with 5 $\mathrm{ml}$ PBS. Animals were killed $48 \mathrm{~h}$ after injection of the mAbs. Each group represents five animals. The severity of EAMG was established by a strength duration test performed according to Lennon et al[13]. Clinical signs of EAMG were expressed as 0 (no obvious abnormalities), + (no abnormalities before testing, but decreased strength at the end), ++ (clinical signs before testing, i. e. head down, hunched posture, weak grip) and +++ (severe clinical signs before testing, no grip, moribund).

Loss of AChR was confirmed by measurement of the muscle AChR concentration in whole carcasses according to Lindstrom et al[12], with minor modification[25]. Briefly, frozen rat (or mouse) muscle was homogenized in a Warring blendor at $4^{\circ} \mathrm{C}$ for 4 x $30 \mathrm{sec}$ in $250 \mathrm{ml}$ (150 ml for mouse) PBS containing $10 \mathrm{mM}$ EDTA, $10 \mathrm{mM} \mathrm{NaN}_{3}, 0.1$ $\mathrm{mM}$ phenylmethylsulfonyl fluoride (PMSF) and 2\% iodoacetamide. After centrifugation at $12000 \mathrm{rpm}$ (Beckman rotor JA14) at $4^{\circ} \mathrm{C}$ for $30 \mathrm{~min}$, the pellet was resuspended in 15 
$\mathrm{ml}$ (10 $\mathrm{ml}$ for mouse) of $2 \%$ Triton X-100 in buffer above and centrifuged again. An aliquot of $250 \mu$ l supernatant (crude extract of muscle AChR) was labeled with $2 \mathrm{nM}{ }^{125} \mathrm{I}-$ $\alpha$-BT and incubated with excess rat anti-AChR IgG at $4{ }^{\circ} \mathrm{C}$ overnight. The complex of rat anti-AChR IgG-AChR- $-{ }^{125} \mathrm{I}-\alpha-\mathrm{BT}$ was precipitated by addition of goat anti-rat serum.

AChR concentration was expressed as pmoles ${ }^{125} \mathrm{I}-\alpha-\mathrm{BT}$ precipitated and percentage of AChR loss was calculated as follows: $1-$ [(average AChR concentration of experimental group / average AChR concentration of control group) x 100].

\section{Results}

Isotypes of $m A b s$

Most of the mAbs were IgG1 and IgG2b and of $\kappa$ type of light chain (see Table 1).

Fine specificity of anti-AChR $m A b s$

MAbs A7, A24, A26 and A60 were able to inhibit more than $50 \%$ binding of reference anti-MIR mAb 35 to AChR, indicating that they were directed against MIR on AChR (see Table 2). Another experiment showed that mAb D6 could inhibit the binding of mAb 35 to hAChR by up to $81 \%$, and inhibit the binding of mAb G10 by $76 \%$, indicating that both D6 and G10 are also anti-MIR or -overlapping MIR mAbs. 
Table 1 Characteristics of anti-AChR mAbs

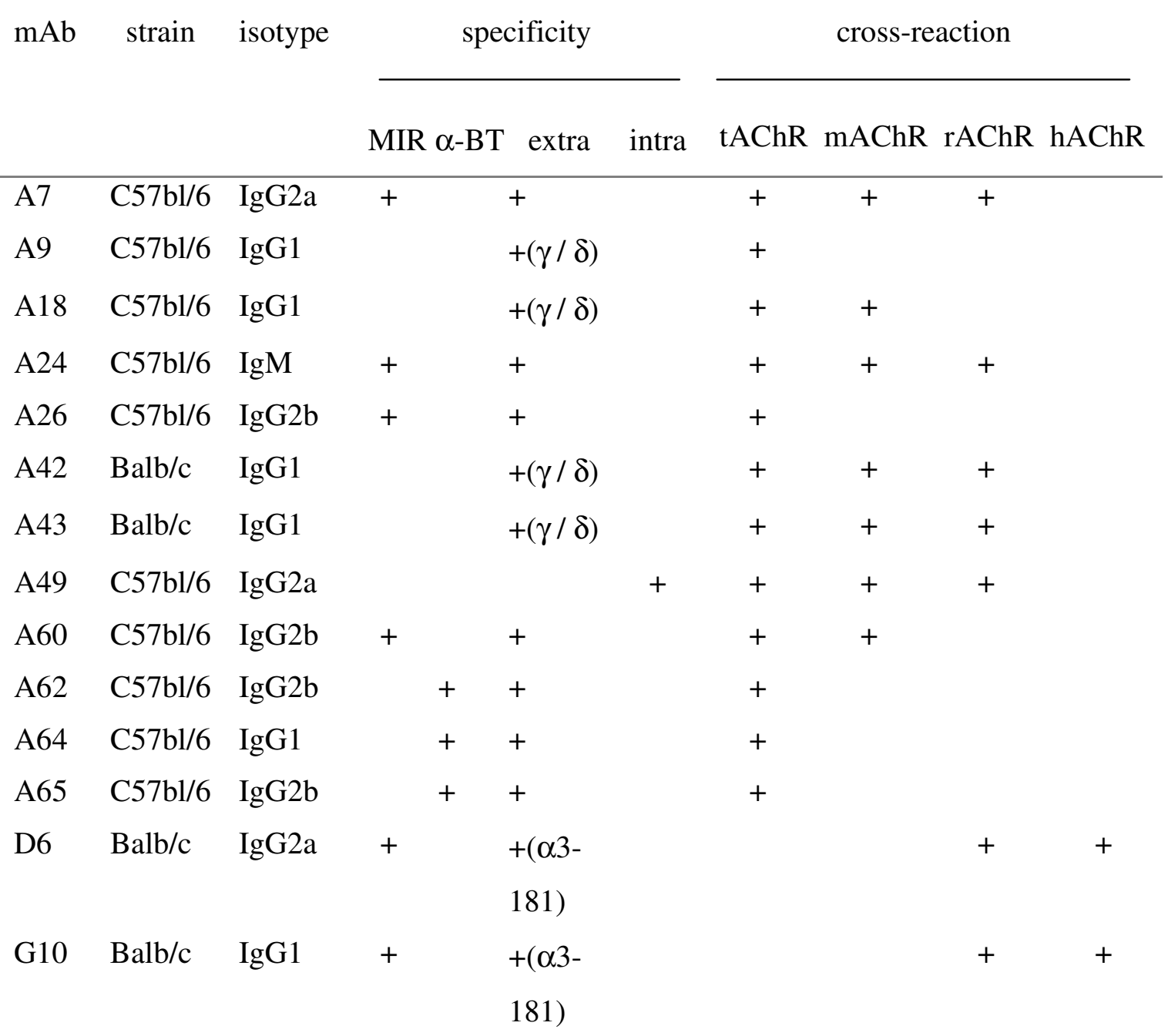

MIR: the main immunogenic region located on the $\alpha$-subunit ( $\alpha 67-76)$ of AChR. $\alpha-\mathrm{BT}$ : $\alpha$ bungarotoxin binding site on the $\alpha$-subunit ( $\alpha 189-195)$ of AChR. extra: epitopes located on the extracellular surface of AChR. intra: epitopes located on the cytoplasmic surface of AChR accessible only on solubilized AChR. tAChR: AChR from electric organs of Torpedo californica. mAChR: AChR from mouse muscle. rAChR: AChR from rat muscle. hAChR: AChR from human muscle. $\gamma / \delta$ : $\gamma$ and $\delta$ subunits of AChR. $\alpha 3-181$ : binding to recombinant $\alpha$-subunit amino acids 3-181 of hAChR determined by Jacobson et al[26]. 
Table 2 Concentrations of anti-MIR mAbs needed for $50 \%$ inhibition of mAb 35 binding to $\mathrm{AChR}\left(\mathrm{IC}_{50}\right)$

\begin{tabular}{cc}
\hline $\mathrm{mAb}$ & $\mathrm{IC}_{50}(\mu \mathrm{g} / \mathrm{ml})$ \\
\hline $\mathrm{A} 7$ & 2 \\
$\mathrm{~A} 24$ & 1.5 \\
$\mathrm{~A} 26$ & 1 \\
$\mathrm{~A} 60$ & 0.4 \\
$\mathrm{mAb} 35$ & 0.35 \\
\hline
\end{tabular}

MAbs A62, A64 and A65 were able to block the binding of ${ }^{125} \mathrm{I}-\alpha-\mathrm{BT}$ to AChR for more than $50 \%$ suggesting that they recognized the epitopes overlapping the $\alpha$-BT binding sites (see Table 3).

Table 3 Concentrations of anti- $\alpha$-BT binding site mAbs needed for $50 \%$ inhibition of

${ }^{125} \mathrm{I}-\alpha-\mathrm{BT}$ binding to $\mathrm{AChR}\left(\mathrm{IC}_{50}\right)$

\begin{tabular}{cc}
\hline $\mathrm{mAb}$ & $\mathrm{IC}_{50}(\mu \mathrm{g} / \mathrm{ml})$ \\
\hline $\mathrm{A} 62$ & 0.3 \\
$\mathrm{~A} 64$ & 0.25 \\
$\mathrm{~A} 65$ & 8.5 \\
\hline
\end{tabular}

MAbs A9, A18, A42 and A43 were unable to inhibit either the binding of mAb 35 to AChR or the binding of ${ }^{125} \mathrm{I}-\alpha-\mathrm{BT}$ to AChR. However, they recognized an extracellular epitope of tAChR as showed in Figure 1. Further determination by Western blotting revealed that they could bind to $\gamma / \delta$ subunits of AChR (data not shown). However, mAb A49 bound to solubilized but not membrane incorporated AChR (see Figure 1). 
A

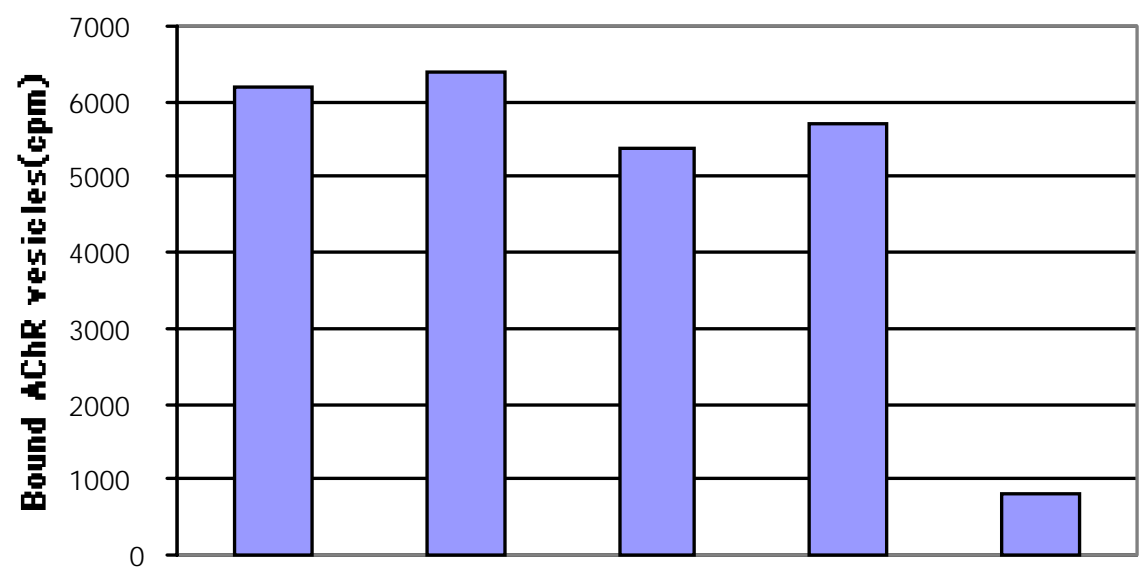

B

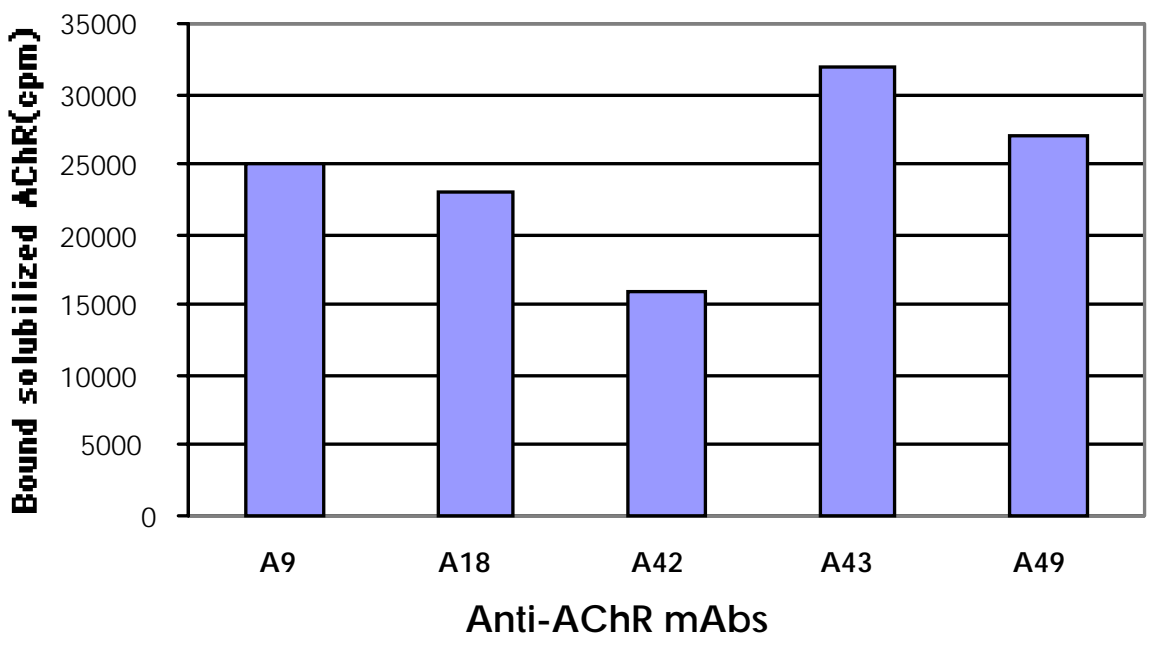

Figure 1 Binding of anti-AChR mAbs to extracellular and intracellular epitopes on AChR. Anti$\mathrm{AChR}$ mAbs were tested for binding to AChR vesicles in which the receptor is embedded in the membrane and only extracellular epitopes are exposed (A) or binding to solubilized AChR on which intracellular epitopes are only accessible for antibodies in vitro (B). 
Cross-reaction with $m A C h R, r A C h R$ and hAChR

The cross-reactivity of anti-tAChR mAbs to AChR of other species was tested by RIA. Some of the mAbs cross-reacted with $\mathrm{mAChR}$, other were able to bind to rAChR (see Table 1).

Pathogenicity of anti-AChR $m A$ bs

Anti-AChR mAbs were tested for in vivo pathogenicity in rats or mice. The animals with EAMG showed AChR loss ranging from $29 \% \pm 14 \%$ to $47 \% \pm 15 \%$ (see Table 4).

Table 4 Pathogenicity of anti-AChR mAbs

\begin{tabular}{lcc}
\hline $\mathrm{mAb}$ & AChR loss $($ mean $\pm \mathrm{SD})$ & EAMG \\
\hline PBS & $0 \pm 7.5$ & 0 \\
$\mathrm{~A} 7$ & $38.4 \pm 7.2$ & +++ \\
$\mathrm{A} 24$ & $13.2 \pm 14.1$ & 0 \\
$\mathrm{~A} 42$ & $0.1 \pm 7.0$ & 0 \\
$\mathrm{~A} 43$ & $4.0 \pm 12.5$ & 0 \\
$\mathrm{~A} 60$ & $48.2 \pm 13.0$ & 0 \\
$\mathrm{D} 6$ & $47.0 \pm 15.0$ & +++ \\
$\mathrm{G} 10$ & $29.0 \pm 14.0$ & ++ \\
\hline
\end{tabular}

Anti-AChR mAbs were investigated for in vivo pathogenicity by passive transfer to rats or mice (mAb A60). AChR loss at $48 \mathrm{~h}$ after injection of mAbs is expressed as a percentage of the AChR concentration of PBS-injected animals measured in whole carcass. Clinical signs of EAMG were evaluated as: +++, severe clinical signs; ++, clinical signs; 0 , no obvious abnormalities. 


\section{Discussion}

MAbs were obtained from hybridomas using pooled lymphnode cells from C57bl/6 and Balb/c mice immunized three times with AChR. Hybridomas were initially screened for binding to AChR by ELISA. The mAbs reactive with AChR were further determined on their isotypes by ELISA, their fine specificity by competitive ELISA or RIA, and their ability to cross-react with mAChR, rAChR and hAChR by RIA. The determination of isotypes of the mAbs will be useful in evaluation of pathogenicity of the mAbs in induction of EAMG and in design of primers used in PCR amplification of mAb variable region gene segments for subsequently sequencing.

It has been known that a major part of anti-AChR antibodies in MG and EAMG in rats immunized with intact AChR are directed against the MIR located on the $\alpha$ subunit at residues 67-76[27,28]. Anti-MIR antibodies are very potent in accelerating AChR degradation by antigenic modulation[29] and are able to induce EAMG in animals by passive transfer[30]. Mouse mAbs against the MIR were distinguished from mAbs to other extracellular epitopes on AChR by competitive inhibition with reference anti-MIR $\mathrm{mAb} 35[31]$. Varying amounts of these mAbs were needed to inhibit mAb 35 to bind to AChR for $50 \%$, indicating that these mAbs show varying affinities for MIR or recognize epitopes partially overlapping the MIR, since mAbs with fine specificity for epitopes separated by only 7 residues can be distinguished using this competitive inhibition technique[23]. Since pathogenic anti-AChR antibodies were exclusively found among the anti-MIR antibodies, therefore, this group of antibodies will be used in analysis of the pathogenicity related with their molecular sequences of variable region genes (see Chapter 2). The $\alpha$-BT binding site, including the cholinergic binding site, is located on the $\alpha$-subunit ( $\alpha 189-195)$ distinct from the MIR[7]. MAbs A62, A64 and A65 were isolated that competitively inhibited the binding of $\alpha$-BT to the AChR. MAbs A64 and A65 were able to inhibit $\alpha$-BT binding almost completely, whereas mAb A62 inhibited $\alpha$-BT biding to a maximum of $50 \%$. MAbs completely inhibiting $\alpha$-BT are probably directed to epitopes similar for both $\alpha$-BT binding sites on each AChR molecule, whereas 
mAbs partially inhibiting $\alpha$-BT are directed to epitopes unique to each of the two binding sites [7-9].

The AChR is a transmembrane glycoprotein with extracellular epitopes accessible for antibody in vivo and intracellular epitopes only accessible on solubilized AChR in vitro. Since anti-AChR mAbs are generated against solubilized AChR both antibodies against extracellular and intracellular epitopes will arise. MAbs binding to extracellular epitopes can be distinguished from mAbs to intracellular epitopes by binding to AChRrich membrane vesicles. MAbs A9, A18, A42 and A43 which failed to inhibit the binding of $\mathrm{mAb} 35$ or $\alpha$-BT to $\mathrm{AChR}$, are directed against an extracellular epitope and $\gamma / \delta$ subunits confirmed further by Western blotting, whereas mAb A49 recognized only the intracellular epitopes.

Since the AChR is an evolutionary well conserved molecule[32, 33], the homology between Torpedo and mammalian AChR is about $80 \%$ for the $\alpha$-subunit and $55 \%$ for the other subunits[34-37], and the amount of AChR in electric organs of Torpedo californica and other electric rays and eels is 100000 as high as that in mammalian skeletal muscle per kilogram muscle weight, therefore, tAChR provides a rich source of AChR used in mammalian study. Furthermore, since mAbs cross-reactive with mammalian AChR could be pathogenic in vivo, they could be used to induce EAMG as a model to investigate the pathogenesis of $\mathrm{MG}$ as well as to analyse the structure of pathogenic anti-AChR antibodies in relation to their pathogenicity.

\section{Acknowledgements}

The authors wish to thank Dr S. J. Tzartos for supplying mAb 35 and Dr A. Vincent for mAbs D6 and G10. This work was supported by grants from Het Prinses Beatrix Fonds and L'Association Francaise contre les Myopathies. 


\section{References}

1 Graus Y, de Baets M. Myasthenia gravis: an autoimmune response against the acetylcholine receptor. Immunol Res, 1993, 12: 78-100

2 Kao I, Drachman DB. Myasthenic immunoglobulin accelerates acetylcholine receptor degradation. Science, 1977, 196: 527-529

3 Drachman DB, Angus CW, Adams RN, Michelson JD, Hoffman GJ. Myasthenic antibodies cross-link acetylcholine receptors to accelerate degradation. $N$ Eng J Med, 1978, 298: 1116-1122

4 Engel AG, Lambert EH, Howard FM. Immune complexes (IgG and C3) at the motor endplate in myasthenia gravis. Ultrastructural and light microscopic localization and electrophysiologic correlations. Mayo Clin Proc, 1977, 52: 267-280

5 Sahashi K, Engel AG, Lambert EH, Howard FM. Ultrastructural localization of the terminal and lytic ninth complement component (C9) at the motor endplate in myasthenia gravis. J Neuropathol Exp Neurol, 1980, 37: 213-233

6 Gomez CM, Richman DP, Berman PW, Burres SA, Arnason BGW, Fitch FM. Monoclonal antibodies against purified nicotinic acetylcholine receptor. Biochem Biophys Res Commun, 1979, 88: 575-582

7 Watters D, Maelicke A. Organization of ligand binding sites at the acetylcholine receptor: A study with monoclonal antibodies. Biochemistry, 1983, 22: 1811-1819

8 Whiting P, Vincent A, Newsom-Davis J. Monoclonal antibodies to Torpedo acetylcholine receptor. Characterisation of antigenic determinants within the cholinergic binding site. Eur J Biochem, 1985, 150: 533-539

9 Dowding AJ, Hall ZM. Monoclonal antibodies specific for each of the two toxinbinding sites of Torpedo acetylcholine receptor. Biochemistry, 1987, 26: 6372-6381

10 Cleveland WL, Wasserman NH, Sarangarajan R, Penn AS, Erlanger BF. Monoclonal antibodies to the acetylcholine receptor by a normally functioning auto-anti-idiotypic mechanism. Nature, 1983, 305: 56-57

11 Donnelly A, Mihovilovic M, Gonzalez-Ros JM, Ferragut JA, Richman D, MartinezCarrion M. Noncholinergic site-directed monoclonal antibody can impair agonist- 
induced ion flux ion Torpedo californica acetylcholine receptor. Proc Natl Acad Sci USA, 1984, 81: 7999-8003

12 Lindstrom JM, Einarson BL, Lennon VA, Seybold ME. Pathological mechanisms in experimental autoimmune myasthenia gravis. I. Immunogenicity of syngeneic acetylcholine receptor and quantitative extraction of receptor and antibody-receptor complexes from muscles of rats with experimental autoimmune myasthenia gravis. $J$ Exp Med, 1976, 144: 726-738

13 Lennon VA, Lindstrom JM, Seybold ME. Experimental autoimmune myasthenia gravis: a model of myasthenia gravis in rats and guinea pigs. $J$ Exp Med, 1975, 141: $1365-1375$

14 Gomez C, Richman D. Anti-acetylcholine receptor antibodies directed against the $\alpha$ BT binding site induce an unique form of experimental myasthenia. Proc Natl Acad Sci USA, 1983, 80: 4089-4093

15 Tzartos SJ, Kokla A, Walgrave S, Conti-Tronconi B. Localization of the main immunogenic region of the human muscle acetylcholine receptor to residues 67-76 of the $\alpha$-subunit. Proc Natl Acad Sci USA, 1988, 85: 2899-2903

16 Almon RR, Andrew CG, Appel SH. Serum globulin in myasthenia gravis: inhibition of $\alpha$-bungarotoxin binding to acetylcholine receptors. Science, 1974, 186: 55-57

17 Pachner AR. Anti-acetylcholine receptor antibodies block bungarotoxin binding to native human acetylcholine receptor on the surface of TE671 cells. Neurology, 1989, 39: $1057-1061$

18 Graus Y, van Breda Vriesman P, de Baets M. Characterization of anti-acetylcholine receptor $(\mathrm{AChR})$ antibodies from mice differing in susceptibility for experimental autoimmune myasthenia gravis (EAMG). Clin Exp Immunol, 1993, 92: 506-513

19 Whiting P, Vincent A, Schluep M, Newsom-Davis J. Monoclonal antibodies that distinguish between normal and denerved human acetylcholine receptor. $J$ Neuroimmunol, 1986, 11: 223-235

20 Lindstrom J, Anholt R, Einarson B, Engel A, Osame M, Montal M. Purification of acetylcholine receptors, reconstitution into lipid vesicles, and study of agonistinduced cation channel regulation. J Biol Chem, 1980, 255: 8340-8350

21 Kohler G, Milstein C. Continuous cultures of fused cells secreting antibody of predefined specificity. Nature, 1975, 256: 495-497 
22 Kordossi AA, Tzartos SJ. Monoclonal antibodies against the main immunogenic region of the acetylcholine receptor: mapping on the intact molecule. $J$ Neuroimmunol, 1989, 23: 35-40

23 Kordossi A Tzartos SJ. Conformation of cytoplasmic segments of acetylcholine receptor alpha- and beta-subunits probed by monoclonal antibodies: sensitivity of the antibody competition approach. EMBO J, 1987, 6: 1605-1610

24 Graus Y, Meng F, Vincent A, van Breda Vriesman P, de Baets M. Sequence analysis of anti-AChR antibodies in experimental autoimmune myasthenia gravis. J Immunol, 1995, 154: 6382-6396

25 Verschuuren F, Graus Y, Theunissen R, Yamamoto T, Vincent A, van Breda Vriesman P, de Baets M. Role of acetylcholine receptor antibody complexes in muscle in experimental autoimmune myasthenia gravis. J Neuroimmunol, 1992, 36: $117-125$

26 Jacobson L, Beeson D, Tzartos S, Vincent A. Monoclonal antibodies raised against human acetylcholine recptor bind to all five subunits of the fetal isoform. $J$ Neuroimmunol, 1999, 98: 112-120

27 Tzartos SJ, Lindstrom JM. Monoclonal antibodies used to probe acetylcholine receptor structure: localization of the main immunogenic region and detection of similarities between subunits. Proc Natl Acad Sci USA, 1980, 77: 755-759

28 Tzartos SJ, Seybold ME, Lindstrom JM. Specificities of antibodies to acetylcholine receptors in sera from myasthenia gravis patients measured by monoclonal antibodies. Proc Natl Acad Sci USA, 1982, 79: 188-192

29 Tzartos SJ,Sophianos D, Efthimiadis A. Role of the main immunogenic region of the acetylcholine receptor in myasthenia gravis. An Fab monoclonal antibody protects against antigenic modulation by human sera. J Immunol, 1985, 134: 2343-2349

30 Tzartos SJ, Hochschwender S, Vasquez P, Lindstrom J. Passive transfer of experimental autoimmune myasthenia gravis by monoclonal antibodies to the main immunogenic region of the acetylcholine receptor. J Neuroimmunol, 1987, 15: 185194

31 Tzartos SJ, Rand DE, Einarson BE, Lindstrom JM. Mapping of surface structures of electrophorus acetylcholine receptors using monoclonal antibodies. J Biol Chem, 1981, 256: 8635-8645 
32 Noda M, Takahashi H, Tanabe T, Toyosato M, Kikotani S, Furrtani Y, Hirose T, Takashima H, Inayama S, Miyata T, Numa S. Structural homology of Torpedo californica acetylcholine receptor subunits. Nature, 1983, 302: 528-532

33 Popot J-L, Changeux J-P. Nicotinic receptor of acetylcholine: structure of an oligomeric integral membrane protein. Physiol Rev, 1984, 64: 1162-1239

34 Noda M, Furutani Y, Takahashi H, Toyosato M, Tanabe T, Shimizu S, Kidyotani S, KayanoT, Hirose T, Inayama S, Numa S. Cloning and sequence analysis of calf cDNA encoding $\alpha$-subunit precursor of muscle acetylcholine receptor. Nature, 1983, 305: $818-823$

35 Tanabe T, Noda M, Furutani Y, Takai T, Takahashi H, Tanaka K, Hirose T, Inayama S, Numa S. Primary structure of $\beta$ subunit precursor of calf muscle acetylcholine receptor deduced form cDNA sequence. Eur J Biochem, 1984, 144: 11-17

36 Takai T, Noda M, Furutani Y, Takahashi H, Notake M, Shimizu S, KayanoT, Tanabe T, Tanaka K, Hirose T, Inayama S, Numa S. Primary structure of $\gamma$ subunit precursor of calf-muscle acetylcholine receptor deduced from the cDNA sequence. Eur $J$ Biochem, 1984, 143: 109-115

37 Kubo T, Noda M, Takai T, Tanabe T, Kayana T, Shimizu S, Tanaka K, Takahashi H, Hirose T, Inayama S, Kikuno R, Miyata T, Numa S. Primary structure of $\delta$ subunit precursor of calf muscle acetylcholine receptor deduced from cDNA sequence. Eur $J$ Biochem, 1984, 149: 5-13 


\title{
Chapter 2
}

\section{Pathogenicity and sequence analysis of monoclonal antibodies directed against the main immunogenic region of acetylcholine receptor}

\begin{abstract}
Binding of autoantibodies directed against acetylcholine receptor (AChR) to AChR results in AChR loss leading to muscular weakness in myasthenia gravis (MG) and its animal model, experimental autoimmune myasthenia gravis (EAMG). The role of different anti-AChR antibody sequences and specificities in pathogenesis of EAMG was investigated by sequencing a panel of 6 anti-AChR monoclonal antibodies (mAbs) against main immunogenic region (MIR). The EAMG was induced in rats or mice by passive transfer of the mAbs and evaluated by clinical signs and AChR loss. The variable regions of heavy and light chains of anti-MIR mAbs were sequenced. Comparison of the sequences at nucleotide and amino acid levels between the mAbs showed that they utilized a similar VH gene derived from mouse PC7183 germline family with high homology in complementarity determining region (CDR) 1 and 2. The large diversity found in heavy chain CDR3 of the anti-MIR mAbs may contribute to the difference in pathogenicity of the mAbs.
\end{abstract}




\section{Introduction}

Myasthenia gravis (MG) is an organ-specific autoimmune disease mediated by autoantibodies directed against acetylcholine receptor (AChR) on postsynaptic membrane in neuromuscular junction[1,2]. Muscle-type AChR in neuromuscular junction is a complex transmembrane glycoprotein of molecular weight $290 \mathrm{KD}$, consisting of five subunits in a stochiometry $\alpha_{2} \beta \gamma \delta[3-5]$. A characteristic feature of the AChR is the presence of main immunogenic region (MIR) to which more than half of the autoantibodies in MG patients or experimental MG rats are directed[6-8]. The MIR is located on the $\alpha$-subunit at residues 67-76[9-11] and easily accessible in vivo to antibodies.

The model of MG, experimental autoimmune myasthenia gravis (EAMG) can be induced in animals by immunization of purified AChR or passive transfer of anti-AChR antibodies[12-15]. Pathogenic anti-AChR monoclonal antibodies (mAbs) were found exclusively among the mAbs directed against MIR. Binding of anti-AChR antibodies to AChR causes cross-linking of adjacent AChR molecules resulting in accelerating AChR internalization[16] or activate complement cascade leading to focal lysis of postsynaptic membrane[15]. The lack of functional AChR leads to muscular weakness and paralysis of skeletal muscle.

The actual contribution of individual antibodies to the antibody-mediated AChR loss is an important question in the pathogenesis of MG. Further structural and functional analysis of pathogenic anti-AChR antibody specificity may contribute to the understanding of the pathogenic mechanisms. In the study presented here, a panel of 6 anti-MIR mAbs was investigated by sequencing the variable regions $(\mathrm{V})$ of heavy $(\mathrm{H})$ and light (L) chains of the mAbs[17]. 


\section{Materials and methods}

Anti-AChR $m A b s$

Hybridomas were made according to Kohler and Milstein[18] from C57bl/6 and Balb/c mice immunized with Torpedo AChR (tAChR), purified from electric organ of Torpedo californica (Pacific Biomarine, California, USA) by affinity chromatography on Naja naja siamensis toxin (Miami Serpentaricem, Florida, USA) linked to Sepharose-4B (Pharmacia LKB, Woerden, The Netherlands), and with human AChR (hAChR), purified from amputated limbs of a patient without vascular or neurological disease as above. MAbs were initially screened for reactivity to AChR by ELISA as described previously in Chapter 1.

Anti-MIR mAbs

MAbs A7, A24, A26, A60 and D6 were determined on their fine specificity to bind to MIR on AChR by a competitive inhibition ELISA using mAb 35[19] (a kind gift of Dr S. J. Tzartos, Institute Pasteur Hellenique, Athens, Greece) as a reference anti-MIR antibody. The mAbs with more than 50\% inhibition of mAb 35 to AChR were considered as anti-MIR antibodies[20]. MAb G10 was tested on its specificity to bind hAChR in a competitive inhibition between mAbs G10 and D6 (see Chapter 1).

\section{Pathogenicity of anti-MIR mAbs}

The potential of anti-MIR mAbs to induce clinical signs of EAMG was determined by passive transfer of anti-MIR mAbs to 8-10 week-old female Lewis rats[21] (for mAbs A7, A24, D6 and G10) or 8 week-old female C57bl/6 mice (for mAb A60). Passive transfer EAMG was induced by i. p. injection of 20 fold concentrated culture supernatant of anti-MIR mAbs in final volume of $5 \mathrm{ml}$. Control rats were injected with $5 \mathrm{ml}$ PBS. Animals were killed $48 \mathrm{~h}$ after injection of the mAbs. Each group represents five animals. The severity of EAMG was established by a strength duration test performed according 
to Lennon et al[22]. Clinical signs of EAMG were expressed as 0 (no obvious abnormalities), + (no abnormalities before testing, but decreased strength at the end), ++ (clinical signs before testing, i. e. head down, hunched posture, weak grip) and +++ (severe clinical signs before testing, no grip, moribund).

Loss of AChR was confirmed by measurement of the muscle AChR concentration in whole carcasses according to Lindstrom et al[23], with minor modification[24]. Briefly, frozen rat (or mouse) muscle was homogenized in a Warring blendor at $4^{\circ} \mathrm{C}$ for 4 x $30 \mathrm{sec}$ in $250 \mathrm{ml}$ (150 ml for mouse) PBS containing $10 \mathrm{mM} \mathrm{EDTA} 10 \mathrm{mM} \mathrm{NaN}_{3}, 0.1$ $\mathrm{mM}$ phenylmethylsulfonyl fluoride (PMSF) and 2\% iodoacetamide. After centrifugation at $12000 \mathrm{rpm}$ (Beckman rotor JA14) at $4^{\circ} \mathrm{C}$ for $30 \mathrm{~min}$, the pellet was resuspended in 15 $\mathrm{ml}$ (10 $\mathrm{ml}$ for mouse) of 2\% Triton X-100 in buffer above and centrifuged again. An aliquot of $250 \mu$ l supernatant (crude extract of muscle AChR) was labeled with $2 \mathrm{nM}{ }^{125} \mathrm{I}$ $\alpha$-bungarotoxin ( $\alpha$-BT) and incubated with excess rat anti-AChR $\operatorname{IgG}$ at $4{ }^{\circ} \mathrm{C}$ overnight. The complex of rat anti-AChR IgG-AChR $-{ }^{125} \mathrm{I}-\alpha-\mathrm{BT}$ was precipitated by addition of goat anti-rat serum. AChR concentration was expressed as pmoles ${ }^{125} \mathrm{I}-\alpha-\mathrm{BT}$ precipitated and percentage of AChR loss was calculated as follows: 1 - [(average AChR concentration of experimental group / average AChR concentration of control group) x 100].

\section{Amplification of variable region genes of $m A b s$}

Total RNA was isolated from 1-5 x $10^{6}$ hybridoma cells secreting the mAbs using RNAzol (Cinna/Biotecx Laboratories Inc, Houston TX, USA). Oligo dT primed first strand cDNA was synthesized using AMV reverse transcriptase (Promega,USA) and used as a template for PCR amplification. The upstream primers used for $\mathrm{H}$ and $\mathrm{L}$ chain $\mathrm{V}$ region sequence amplification are based on a consensus sequence of the first 8 codons of the VH and VL domains according to Orlandi et al[25] and Kabat et al[26] with minor modification. The downstream primer for the VH is complementary to codons 120-126 within the $\mathrm{CH} 1$ domain of all $\mathrm{IgG}$ subclasses. The downstream primer for the VL is complementary to codons $114-122$ of the $\mathrm{C} \kappa$ domain. The complete sequences of primers are: VH upstream: 5' gg gaattc (gc)ag gt(gc) (ac)a(ag) ct(gt) cag (gc)ag tc(at) gg, CH1 downstream: 5' gg ggatcc agg ggc cag tgg ata ga(tc) ag, VL upstream: 5' cct gaattc gac 
(ag) tt gt(gt) (ac)t(gc) acc ca(ag) (at)ct cc, Cא downstream: 5' cct ggatcc act gga tgg tgg gaa gat gga tac. The sequences underlined are Eco R1 and Bam $\mathrm{H} 1$ recognition sites to facilitate the subsequent cloning. The PCR was run for 30 cycles with denaturation at 94 ${ }^{\circ} \mathrm{C}$ for $2 \mathrm{~min}$, annealing at $55{ }^{\circ} \mathrm{C}$ for $1 \mathrm{~min}$, and extension at $72{ }^{\circ} \mathrm{C}$ for $1.5 \mathrm{~min}$ in each cycle on DNA Thermal Cycler 480 (Perkin Elmer Cetus).

\section{Sequencing of $m A b s$}

The PCR products of VH and VL were digested with Eco R1 and Bam H1 and purified from $1 \%$ agarose gel with Geneclean kit (BIO 101 Inc, La Jolla, CA, USA), and ligated onto plasmid Bluescript M13 SK (Stratagene, La Jolla, CA, USA). The recombinant plasmids were transferred into E coli DH5 $\alpha$ and analysed for an insert of the right size by digestion with Eco R1 and Bam H1. The dideoxy chain termination sequencing procedure was performed according to Sanger et al[27] using the Bluescript KS and SK primer sites and a T7 sequencing kit (Pharmacia, Woerden The Netherlands). Several independent clones and at least three different colonies of each $\mathrm{H}$ chain and $\mathrm{L}$ chain of each anti-AChR mAb were sequenced to confirm the determined VH and VL sequences.

\section{Sequence comparison}

Mutual homology of sequences at the nucleotide level between anti-AChR mAbs was determined both for the overall $\mathrm{VH}$ and $\mathrm{VL}$ regions and for the complementarity determining regions (CDRs) using the program DNAsis. Homology between anti-AChR mAbs and other antibodies in EMBL Data Library was performed by FASTA computer search. The sequences of VH and VL of mAbs A7, A24, A26, A60, D6 and G10 have been accepted by the EMBL Data Library as AC No (VH and VL): A7: X80962 and X80961, A24: X80972 and X80971, A26: X80970 and X80969, A60: X80954 and X80953, D6: X80942 and X80941, G10: X80940 and X80939. 


\section{Results}

Characteristics of anti-MIR mAbs

The isotype, specificity and cross-reactivity of anti-MIR mAbs A7, A24, A26, A60, D6 and G10 were summarized in Table 1.

Table 1 Characteristics of anti-AChR mAbs

\begin{tabular}{lllll}
\hline mAb & isotype & specificity & & \\
& & & AChR $^{\mathrm{b}}$ & EAMG $^{\mathrm{c}}$ \\
\hline $\mathrm{A} 7$ & IgG2a & MIR & TMR & +++ \\
$\mathrm{A} 24$ & IgM & MIR & TMR & 0 \\
A26 & IgG2b & MIR & T & nd \\
A60 & IgG2b & MIR & TM & 0 \\
D6 & IgG2a & MIR & HR & +++ \\
G10 & IgG1 & MIR & HR & ++ \\
\hline
\end{tabular}

${ }^{a}$ MIR: main immunogenic region. MAbs compete for binding to AChR with anti-MIR mAb 35[19] in ELISA.

${ }^{b}$ Cross-reactivity of mAbs with AChR from Torpedo (T), mouse (M), rat $(\mathrm{R})$ and human $(\mathrm{H})$ in RIA. Torpedo AChR was used as initial immunogen for A7, A24, A26 and A60, and human AChR for D6 and G10.

${ }^{c}$ Pathogenicity of mAbs to induce EAMG in Lewis rats or C57bl/6 mice (A60). Clinical signs were evaluated $48 \mathrm{~h}$ after injection of mAbs. +++: severe clinical signs, ++: clinical signs, 0: no obvious abnormalities, nd: not determined. 
Pathogenicity of anti-MIR $m A$ bs

MAbs A7, A24, A26, D6 and G10 were tested for capacity to induce EAMG in rats and mice. Rats receiving A7 already developed grade +++ muscular weakness $18 \mathrm{~h}$ after injection (Table 1). At this time point mAb A7-injected rats showed 38.4\% \pm 7.2\% AChR loss (Figure 1). All other animals were killed $48 \mathrm{~h}$ after injection. At this time point, animals with EAMG showed AChR loss ranging from $29 \% \pm 14 \%$ to $47 \% \pm 15 \%$. Rats receiving mAb A24 did not develop significant clinical signs of EAMG or AChR loss. MAb A60 induced highly significant AChR loss but no clinical signs of EAMG when injected in mice (Table 1 and Figure 1).

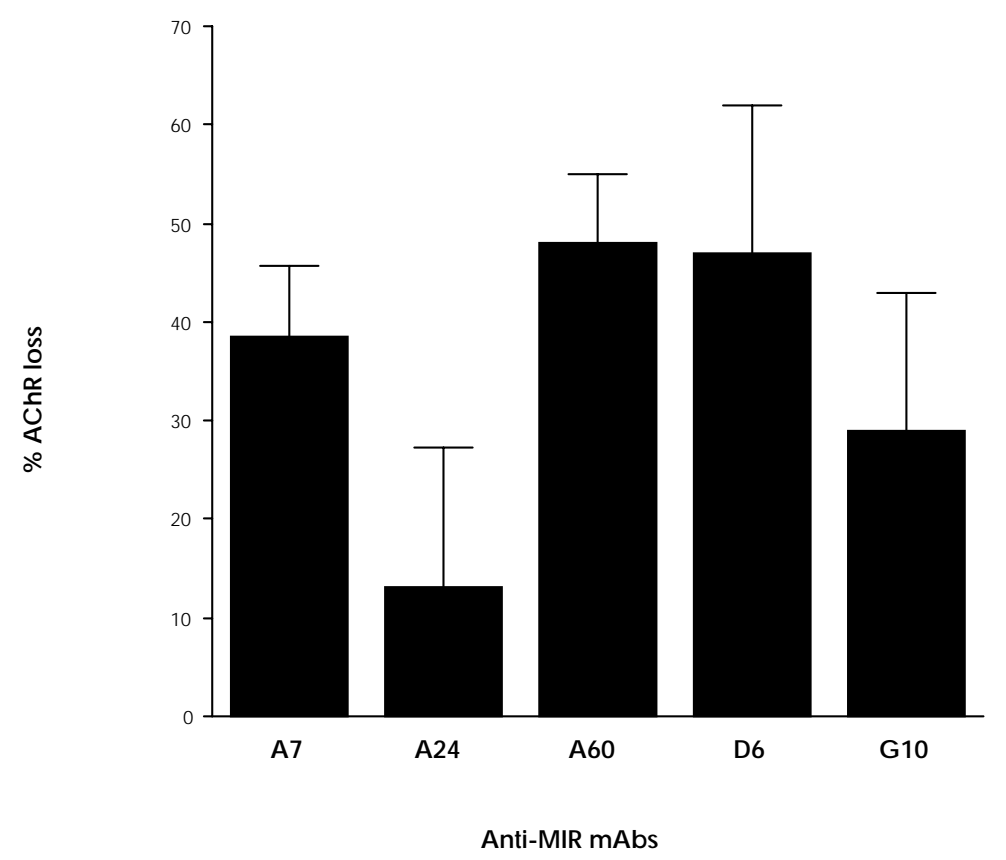

Figure 1 AChR loss after passive transfer of mAbs. AChR concentration was determined $48 \mathrm{~h}$ after injection of mAbs in RIA and expressed as pmoles ${ }^{125} \mathrm{I}-\alpha$-bungarotoxin precipitated. AChR loss is expressed as percentage of AChR concentration in unmanipulated animals 
The $\mathrm{H}$ chain variable region gene of mAb A7 is $345 \mathrm{bp}$ in length (the first $24 \mathrm{bp}$ in $\mathrm{VH}$ upstream primer not included) encoding 115 amino acids and determining the codons 9113 of $\mathrm{VH}$ (Figure 2A). The mAb A7 uses a $\mathrm{VH}$ gene belonging to mouse germline family PC7183. The homology between mAb A7 and germline gene DFL 16.2 VH sequence[28] is 93.7\%. The A7 VH gene is joined with $\mathrm{D}$ and $\mathrm{JH}$ gene belonging to $\mathrm{JH} 4$ segment[29]. MAbs A24 and A26 use almost the same VH gene which is also derived from mouse germline family PC7183. The homology between mAbs A24 and A26 and germline gene VH61-1P[30] is $95.2 \%$ and $95.6 \%$ respectively. MAb A60 also uses mouse germline family PC7183 but with a 42 bp deletion in framework 3 region. MAb G10 is $97.4 \%$ homologous to the MOPC21 germline VH gene[31] which belongs to PC7183 family. All the five mAbs above utilize exact mouse JH4 segment (100\% homology)[29]. However, mAb D6 uses a VH gene derived from mouse Q52 germline family (EMBL Data Library, AC No X14515), and joined with D and JH3 segment[29].

The $\mathrm{L}$ chain variable region gene of mAb A7 is $306 \mathrm{bp}$ in length (the first $24 \mathrm{bp}$ in VL upstream primer not included), encoding 102 amino acids and determining the codons 9-107 of VL (Figure 2B). The VL of mAb A7 is a member of the Vk3 subgroup and derived from mouse Vк 21E germline gene (EMBL Data Library, AC No L08207). The A7 VL is associated with $\mathrm{J}_{\kappa}$ belonging to $\mathrm{J}_{\kappa} 2$ segment[32]. MAbs A24 and A26 utilize different $\mathrm{V} \kappa$ genes which are members of mouse $\mathrm{V} \kappa 3$ and $V \kappa 1$ subgroups respectively. However, they both use the same $\mathrm{J}_{\kappa} 2$ gene[32]. Mab A60 uses almost the same L chain as mAbs A7 and A24 do. The VL genes used by mAbs G10 and D6 are

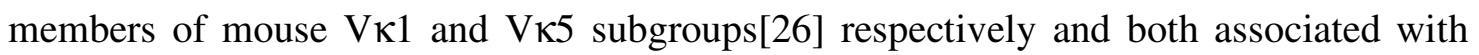
JK1 segment[32].

The $\mathrm{H}$ and $\mathrm{L}$ chain genes encoding six anti-MIR mAbs are summarized in Table 2. 
A

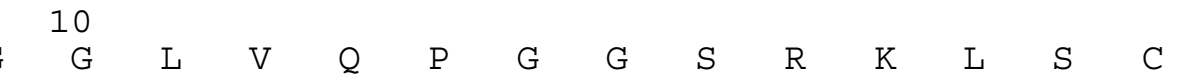
G10 gga ggc tta gtg cag cct gga ggg tcc cgg aaa ctc tcc tgt A60 -- - - - - - - - - - - - - - - - - - - - -

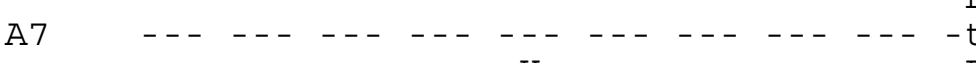

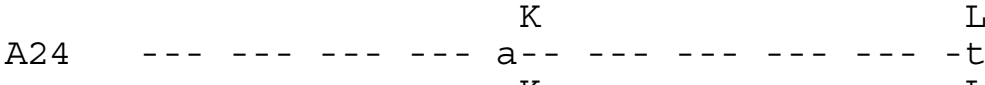

A26 -- - - - - -

D6 cct $--c-g--g c--c$ tc-ca-ag- $-t-t c c a--a-a--c$

$30 \quad$ CDR1

$\begin{array}{lllllllllllllllllll}A & A & S & G & F & T & F & S & S & F & G & M & H & W\end{array}$ G10 gca gcc tct gga ttc act ttc agt agc tet gga atg cac tgg

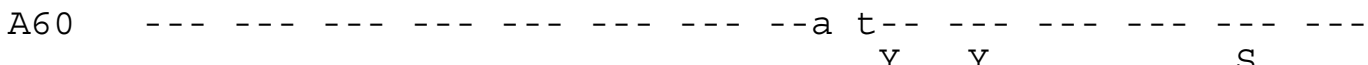

A7 -. - - - - - - - - - - ta - ta- - c - - tct -D Y

A24 -- - - - - - - - - - - - - - ga- - a

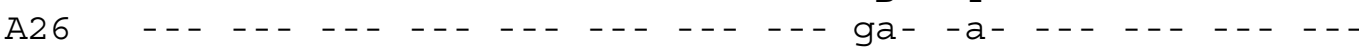

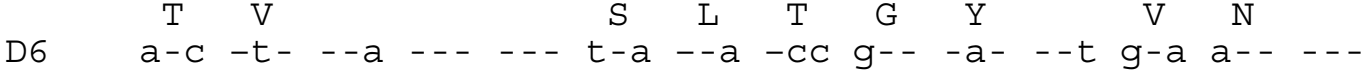

50

$\begin{array}{llllllllllllll}V & R & Q & A & P & E & K & G & L & E & W & V & A & \bar{Y}\end{array}$ G10 gtt cgt cag gct cca gag aag ggg ctg gag tgg gtc gca tac

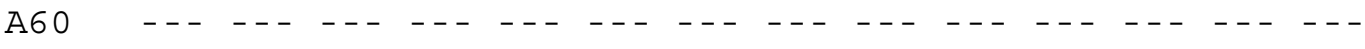

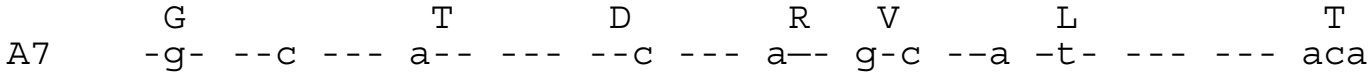
A2 4

A26

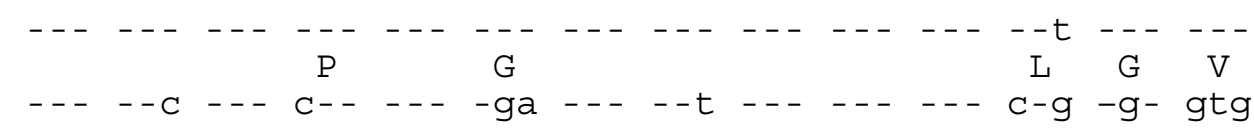

D6 
CDR2

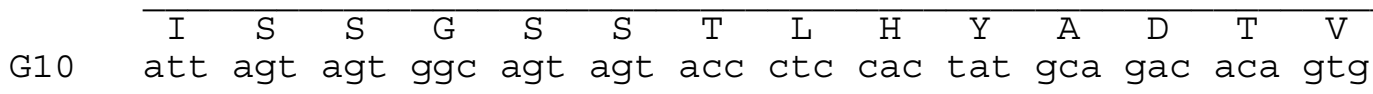

\begin{tabular}{|c|c|c|c|c|c|c|c|c|c|c|c|c|c|c|}
\hline 60 & --- & $\begin{array}{c}--- \\
\mathrm{T}\end{array}$ & --- & $\begin{array}{c}--- \\
\mathrm{N}\end{array}$ & $\begin{array}{c}--- \\
G\end{array}$ & $\begin{array}{c}--- \\
G\end{array}$ & $\begin{array}{c}--- \\
S\end{array}$ & $\begin{array}{c}--- \\
\mathrm{T}\end{array}$ & $\begin{array}{c}--- \\
F\end{array}$ & --- & $\begin{array}{c}--- \\
P\end{array}$ & --- & $\begin{array}{c}--- \\
R\end{array}$ & --- \\
\hline & --- & $\begin{array}{c}-\mathrm{C}- \\
\mathrm{M}\end{array}$ & --- & aat & g-a & $\begin{array}{c}\text { 9-- } \\
R\end{array}$ & $-g-$ & $\mathrm{ac}-$ & $\begin{array}{c}\text { tet } \\
I\end{array}$ & $\begin{array}{c}--- \\
Y\end{array}$ & $C--$ & --- & $-9 g$ & --- \\
\hline & --- & $\begin{array}{c}--g \\
M\end{array}$ & --- & --- & --- & $\begin{array}{c}--a \\
R\end{array}$ & --- & --- & $\begin{array}{c}\mathrm{a}-- \\
\mathrm{I}\end{array}$ & $\begin{array}{c}t-- \\
Y\end{array}$ & --- & --- & --- & --- \\
\hline & --- & $\begin{array}{c}--g \\
W\end{array}$ & --- & --- & $\begin{array}{c}--- \\
D\end{array}$ & $\begin{array}{c}--\mathrm{a} \\
\mathrm{G}\end{array}$ & --- & $\begin{array}{c}--- \\
\mathrm{T}\end{array}$ & $\begin{array}{c}\mathrm{a}-- \\
\mathrm{D}\end{array}$ & $t--$ & $\begin{array}{c}--- \\
\mathrm{K}\end{array}$ & --- & $\begin{array}{c}--- \\
A\end{array}$ & $\begin{array}{c}--- \\
\mathrm{L}\end{array}$ \\
\hline & $-a$ & $t-g$ & & $-t$ & ga- & g-a & $-g-$ & aca & 9-- & -- & aa- & tca & $g-t$ & $C-C$ \\
\hline
\end{tabular}

\begin{tabular}{lllllllllllllll}
\hline $\mathrm{K}$ & $\mathrm{G}$ & $\mathrm{R}$ & $\mathrm{F}$ & $\mathrm{T}$ & $\mathrm{I}$ & $\mathrm{S}$ & $\mathrm{R}$ & $\mathrm{D}$ & $\mathrm{N}$ & $\mathrm{P}$ & $\mathrm{K}$ & $\mathrm{N}$ & $\mathrm{T}$
\end{tabular}

G10 aag gge cga ttc acc atc tcc aga gac at $\mathrm{Cc}$ aag aac acc

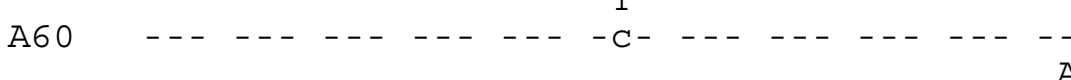

A7

A2 4

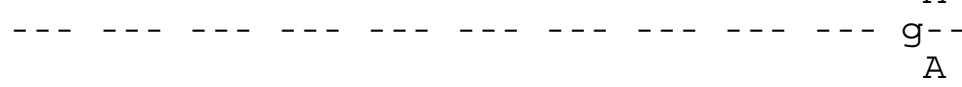

A2 6

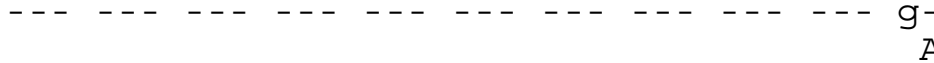

D6

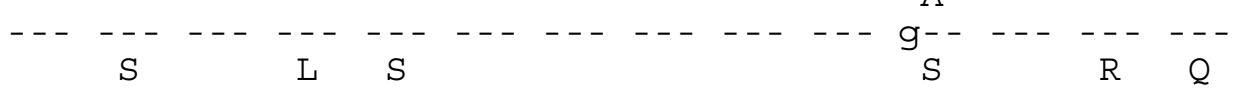

$--a$ tc- a-- c-g -g- --- ag- --g --- - c t-- --- -ga caa

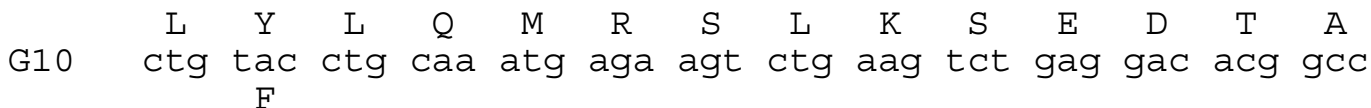
A60 - - - - t - - - - - - -

A 7

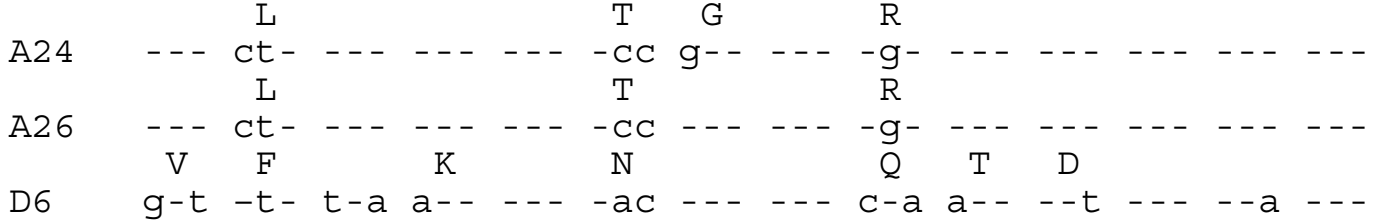


$\begin{array}{lllllllllllllll}M & Y & Y & C & V & R & D & D & S & G & D & S & P & Y\end{array}$

G10 atg tat tac tgt gtg aga gat gat tcg ggg gat agc cca tat

A60

-a- cta ccc--a cta tgc tat

A7

A24

$\begin{array}{lllllllll}A & T & R & K & E & P & L & R & G\end{array}$

A2 6

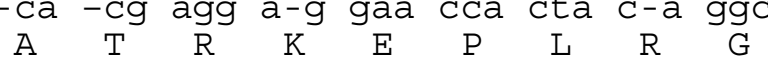

D6

- ca -cg agg a-g gaa cca cta c-a ggc

$\begin{array}{lllllll}R & A & G & G & Y & R\end{array}$

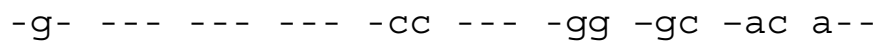

\begin{tabular}{lllllllllllllll}
\hline $\mathrm{Y}$ & $\mathrm{Y}$ & $\mathrm{A}$ & $\mathrm{M}$ & $\mathrm{D}$ & $\mathrm{Y}$ & $\mathrm{W}$ & $\mathrm{G}$ & $\mathrm{Q}$ & $\mathrm{G}$ & $\mathrm{T}$ & $\mathrm{S}$ & $\mathrm{V}$ & $\mathrm{T}$
\end{tabular}

G10 tac tat get atg gac tac tgg ggt caa gga acc tca gtc acc

A60

A7

A24

A26

D6

$$
\text { F }
$$

\begin{tabular}{|c|c|c|c|}
\hline 310 & $\begin{array}{c}\mathrm{V} \\
\text { gtc }\end{array}$ & $\begin{array}{c}S \\
t c C\end{array}$ & $\begin{array}{c}S \\
\text { tca }\end{array}$ \\
\hline 60 & --- & --- & --- \\
\hline 7 & --- & --- & --- \\
\hline 24 & --- & --- & --- \\
\hline A2 & --- & --- & $\begin{array}{c}--- \\
A\end{array}$ \\
\hline & -- & $--t$ & $9^{--}$ \\
\hline
\end{tabular}




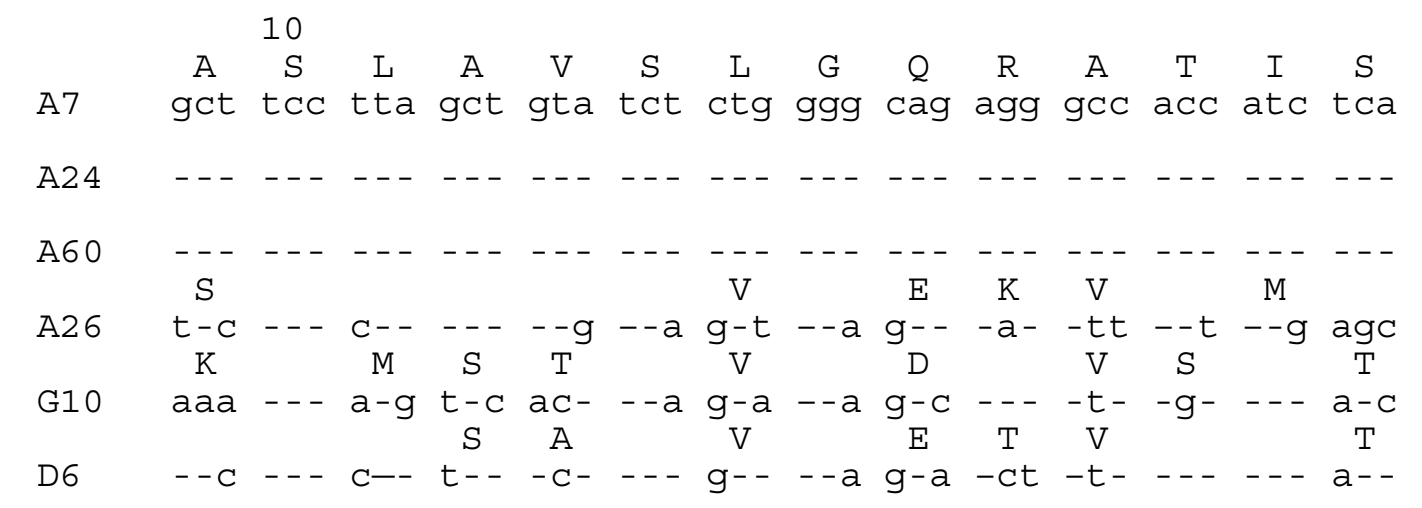

CDR1

$\begin{array}{lllllllll}\mathrm{Y} & \mathrm{R} & \mathrm{A} & \mathrm{S} & \mathrm{K} & \mathrm{S} & \mathrm{V} & \mathrm{S} & \mathrm{T}\end{array}$

A7 tac agg gec agc aaa agt gtc agt aca tct ggc tat

A24 - - - - - - - -

A60 $\begin{array}{ccccccccccccc}--- & --- & --- & --- & --- & --- & --- & --- & -- & & & --- & -- \\ \text { C } & \text { K } & S & \mathrm{~S} & \mathrm{~L} & \mathrm{~L} & \mathrm{Y} & \mathrm{S} & \mathrm{N} & \mathrm{N} & \mathrm{Q} & \mathrm{K}\end{array}$

A26 -g- $-a-t---t \quad c-g--c$ c-t tha tat agt aac aa- caa a-g

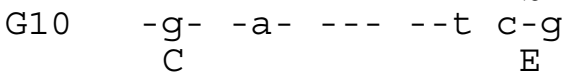

D6 -gt $\mathrm{C}-\mathrm{a}--\mathrm{a}--\mathrm{t} \quad \mathrm{g}-\mathrm{g}$

aa- - tt $\mathrm{Cg}-$

$\mathrm{N} I \mathrm{~N}$

aa- att a-c

\begin{tabular}{lllllllllllllll}
\hline $\mathrm{S}$ & $\mathrm{Y}$ & $\mathrm{M}$ & $\mathrm{H}$ & $\mathrm{W}$ & $\mathrm{N}$ & $\mathrm{Q}$ & $\mathrm{Q}$ & $\mathrm{K}$ & $\mathrm{P}$ & $\mathrm{G}$ & $\mathrm{Q}$ & $\mathrm{P}$ & $\mathrm{P}$
\end{tabular} A7 agt tat atg cac tgg aac caa cag aaa cca gga cag cca ccc A24 $\mathrm{R}$

A60

A2 6

$\mathrm{N} \quad \mathrm{L} \quad \mathrm{A}$

$\begin{array}{cccc}-\mathrm{aC} & --\mathrm{C} & \mathrm{t}-- & \mathrm{gC}- \\ \mathrm{T} & \mathrm{A} & \mathrm{V} & \mathrm{A}\end{array}$

$\mathrm{Y}$

$t-t--t$

G10

$-c-9 C-9-t \underset{L}{9 C-}$

$t---g$
$Y$

$S$

D6

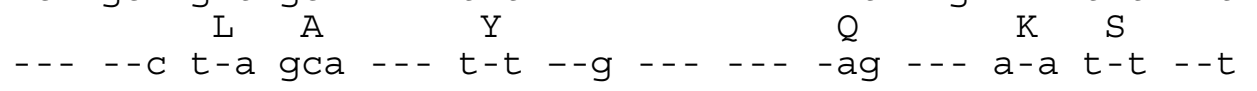


CDR2

$\begin{array}{lllllllllllllllllllllllll}R & \mathrm{~L} & \mathrm{~L} & \mathrm{I} & \mathrm{Y} & \mathrm{L} & \mathrm{V} & \mathrm{S} & \mathrm{N} & \mathrm{L} & \mathrm{E} & \mathrm{S} & \mathrm{G} & \mathrm{V}\end{array}$

aga ctc ctc atc tat ctt gta tcc aac cta gaa tct ggg gtc

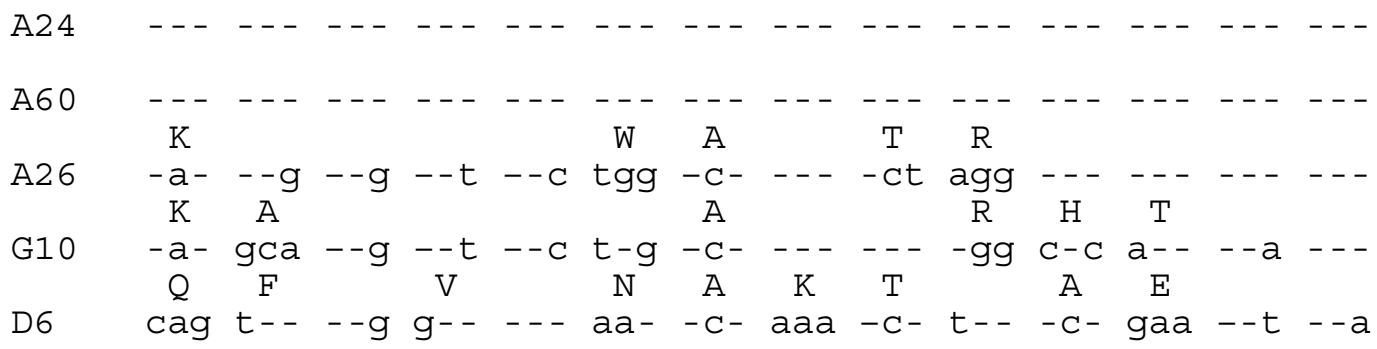

$\begin{array}{llllllllllllllll}\mathrm{P} & \mathrm{A} & \mathrm{R} & \mathrm{F} & \mathrm{S} & \mathrm{G} & \mathrm{S} & \mathrm{G} & \mathrm{S} & \mathrm{G} & \mathrm{T} & \mathrm{D} & \mathrm{F} & \mathrm{T}\end{array}$

cct $9 c c$ agg ttc agt $9 g c$ agt ggg tct ggg aca gac ttc acc

A24

A60

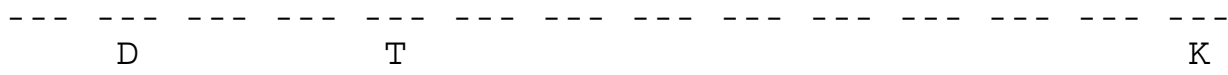

A26

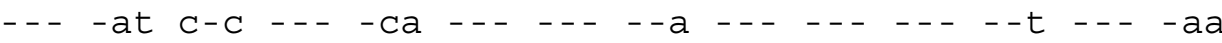

G10

$\mathrm{D}$

$S \quad Q \quad Q \quad S$

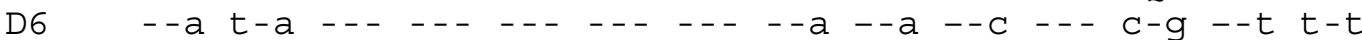

$\begin{array}{llllllllllllll}\mathrm{L} & \mathrm{N} & \mathrm{I} & \mathrm{H} & \mathrm{P} & \mathrm{V} & \mathrm{E} & \mathrm{E} & \mathrm{E} & \mathrm{D} & \mathrm{A} & \mathrm{A} & \mathrm{T} & \mathrm{Y}\end{array}$ A7 ctc aac atc cat cct gtg gag gag gag gat get gca acc tat A2 4

A60

A26

$-\mathrm{C}-$

$\underset{\mathrm{S}}{\operatorname{agc}} \mathrm{ag}-$

a- - $-\mathrm{C}$

$t-a--c c t g$

I

gtt ---

$---\mathrm{c}---\mathrm{t}$ agc aa- -- c-a tct $--\mathrm{a}--\mathrm{c}$ ctg --- gat ---

$\begin{array}{lllllllll}K & N & S & L & Q & P & F & G\end{array}$

D6

$--g--g--$ a-c agc c-- c-- cct --a -- tt- $-g g--t---$ 


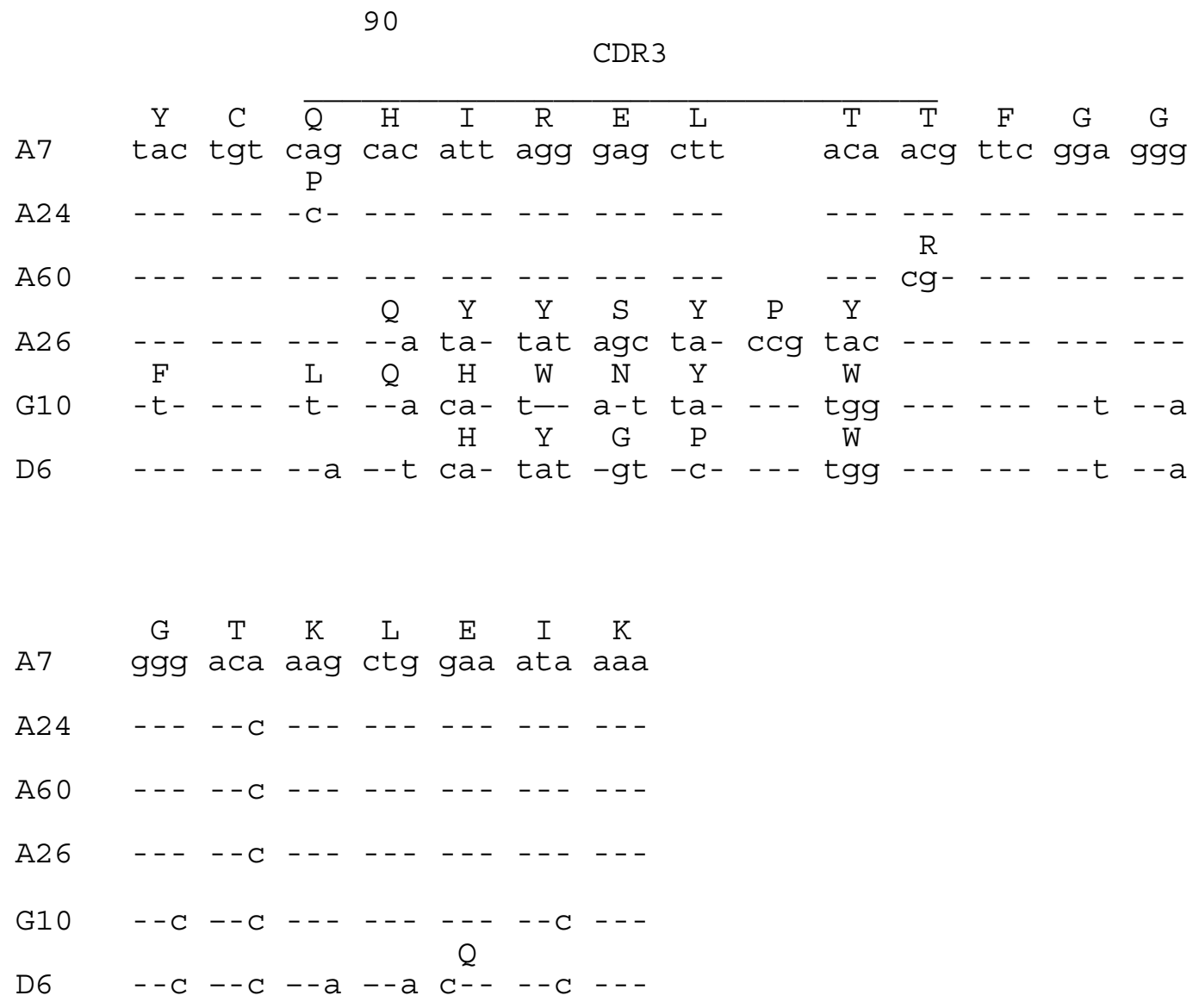

Figure 2 Sequence comparison of anti-MIR mAbs. Sequences of anti-MIR mAbs are compared for the heavy chain (A) and light chain (B). The complete nucleotide sequences and deduced amino acid sequences are aligned starting from codon 9 as numbered according to Kabat et al[26]. Sequence identity of anti-MIR mAbs with mAb G10 (heavy chain) or with mAb A7 (light chain) is indicated by dashes. Complementarity determining regions (CDRs) are also indicated. 
Table 2 Gene utilization of anti-MIR mAbs

\begin{tabular}{cllllll}
\hline & A7 & A24 & A26 & A60 & G10 & D6 \\
& & & & & & \\
\hline H chain & & & & & & \\
VH family & PC7183 & PC7183 & PC7183 & PC7183 & PC7183 & Q52 \\
JH segment & 4 & 4 & 4 & 4 & 4 & 3 \\
L chain & & & & & & \\
Vא subgroup & 3 & 3 & 1 & 3 & 1 & 5 \\
J segment & 2 & 2 & 2 & 2 & 1 & 1 \\
\hline
\end{tabular}

The gene utilization was determined according to the following: VH family: EMBL Data Library,

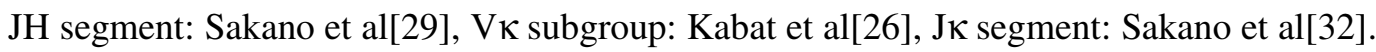

Sequence homology between anti-MIR mAbs

The overall homology among $\mathrm{H}$ chain variable region genes of anti-MIR mAbs derived from the same mouse germline family PC7183 is $80.4 \%-99.7 \%$ with a highest homology of $99.7 \%$ between mAbs A24 and A26 (only 1 nucleotide difference in framework 3). For the $\mathrm{L}$ chain variable region genes, a $98.7 \%$ homology is seen among mAbs A7, A24 and A60, a 77.1\% between mAbs A26 and G10, and a 61.2\% - 64.8\% among others (Table 3 ). 
Table 3 Overall homology of nucleotide sequences of variable regions of anti-MIR mAbs

\begin{tabular}{|c|c|c|c|c|c|c|c|c|c|c|}
\hline \multirow[t]{2}{*}{$\mathrm{mAb}$} & \multicolumn{5}{|c|}{ heavy chain } & \multicolumn{5}{|c|}{ light chain } \\
\hline & A24 & A26 & A60 & G10 & D6 & A24 & A26 & A60 & G10 & D6 \\
\hline A7 & 81.7 & 82.0 & 80.4 & 89.3 & 59.7 & 98.7 & 64.7 & 98.7 & 62.9 & 61.6 \\
\hline A 24 & & 99.7 & 89.1 & 88.2 & 60.4 & & 64.8 & 98.7 & 63.5 & 61.6 \\
\hline A26 & & & 89.1 & 88.5 & 60.7 & & & 64.7 & 77.1 & 64.6 \\
\hline A60 & & & & 92.6 & 57.1 & & & & 62.9 & 61.2 \\
\hline G10 & & & & & 62.0 & & & & & 63.6 \\
\hline
\end{tabular}

Sequence homology is calculated between the complete overlapping VH-D-JH region and shown as percentage of homology

The sequence comparison of $\mathrm{H}$ chain CDRs at amino acid level shows an identical CDRs between mAbs A24 and A26, an identical CDR2 between mAbs A60 and G10, an identical CDR3 between mAbs A7 and G10. The homology is $80 \%$ in CDR1 among A7, A24 (A26), A60 and G10, 76.5\% in CDR2 between A24 (A26) and A60 (G10) (35.3\% - 41.7\% for other antibodies) and 41.7\% in CDR3 between A7 (G10) and A24 (A26) which is 2 amino acids shorter than A7 (G10) in CDR3. MAbs A60 and D6 have only 8 amino acids in CDR3. In contrast, the $\mathrm{H}$ chain of mAb D6 shows only $46.6 \%$ - 60.0\% homology in CDR1, 41.6\% - 60.0\% in CDR2, and 50.0\% - 60.0\% in CDR3 with mAbs A7, A60 and G10. The L chain are identical in CDR1 and 2 and only 1 amino acid different in CDR3 among A7, A24 and A60. Although mAbs A24 and A26 share identical $\mathrm{H}$ chain CDRs, mAb A26, which does not cross-react with mammalian AChR, is encoded by a different $\mathrm{L}$ chain sequence with only $36.6 \%, 57.1 \%$ and $39.1 \%$ homology to A24 in CDR1, 2 and 3 respectively. MAbs G10 and D6 also have different L chain CDRs compared with A7, A24 and A60. 


\section{Discussion}

One of the key questions in the pathogenesis of MG is the contribution of individual antibody specificity to AChR destruction. In this study, a panel of 6 anti-AChR mAbs with fine specificity to MIR was analysed for structural properties in relation to their potential to cause AChR loss and muscular weakness in passive transfer EAMG model. The anti-MIR mAbs cross-reactive to mouse AChR (mAChR) or rat AChR (rAChR) were tested for in vivo pathogenicity. Rats were used instead of mice for the mAbs which could cross-react with both $\mathrm{rAChR}$ and $\mathrm{mAChR}$ since mice are more resistant to induction of EAMG than rats[33]. MAb A7, D6 and G10 could induce AChR loss by up to $29 \%$ - $47 \%$ and severe EAMG demonstrating that they are potent pathogenic anti-MIR mAbs. The mAbs A42 and A43, directed against an extracellular epitope $(\gamma / \delta)$ of AChR and cross-reactive to mAChR and rAChR failed to induce EAMG in rats (see Chapter 1). This finding is in concordance with previous studies in which pathogenicity of anti-MIR mAbs was demonstrated using rat anti-AChR mAbs[15, 34].

The comparison of the variable region nucleotide sequences between anti-MIR mAbs reveals that highly homologous $(80.4 \%$ - 99.7\%) VH-D-JH sequences are found in this group of mAbs. Most of the mAbs (5/6) tested in this study use a similar VH gene derived from mouse germline family PC7183 joined with an unmutated JH4 segment. The nucleotide substitutions seen in the $\mathrm{VH}$ gene utilized by this group of mAbs may result from somatic mutation driven by antigen AChR. MAbs A7, A24 and A60 also share a similar L chain (98.7\% homology among them). However, the L chain used by mAbs A7, A24 and A26 is also frequently shared by anti-DNA antibodies, which are commonly observed in MG patients[35], but non of the anti-MIR mAbs can bind to ss or dsDNA (tested by Dr R. Smeenk, Central Laboratory of Blood Transfusion, Amsterdam, The Netherlands) indicating that the $\mathrm{H}$ chain plays a more important role in the specificity of the mAbs.

The structural features of anti-MIR mAbs in relation to their pathogenicity were investigated by sequence comparison in the CDRs. Pathogenic anti-MIR mAbs A7 and G10 share an identical D-JH4 sequence encoding CDR3, whereas G10 and A60 differ in one amino acid in CDR1 and share an identical CDR2. The CDR3 is considered most 
important in epitope binding, and sharing of an identical CDR3 in A7 and G10 suggests selection for binding to the same determinant of the MIR. Pathogenic mAb D6 shows large sequence diversity in both $\mathrm{H}$ and $\mathrm{L}$ chains compared with mAbs A7 and G10. MAb D6 probably recognizes different determinants or conformation of the MIR since it is a conformation-dependent region on the extracellular tip of $\alpha$-subunit[36]. Even though the MIR is a 10 amino acid epitopes, it elicits several different antibody specificities. Similarly, sequence analysis of mAbs directed against residues 97-107 of tabacco mosaic virus revealed a wide range of different region sequences for both $\mathrm{H}$ and $\mathrm{L}$ chains[37].

In conclusion, sequence analysis of anti-MIR of AChR mAbs shows that the VH genes utilized are related to PC7183 germline family. H chain CDR3 may mainly contribute to the pathogenicity of the mAbs.

\section{Acknowledgements}

We thank Dr S. J. Tzartos for providing us with mAb 35, Dr R. Smeenk for testing antiAChR mAbs binding to DNA, and R. Aarts for technical assistance. This work was supported by grants from Het Prinses Beatrix Fonds and L'Association Francaise contre les Myopathies.

\section{References}

1 Lindstrom J, Shelton D, Fujii Y. Myasthenia gravis. Adv Immunol, 1988, 42: 233-284

2 Graus Y, de Baets M. Myasthenia gravis: an autoimmune response against the acetylcholine receptor. Immunol Res, 1993, 12: 78-100

3 Lindstrom J, Merlie J, Yogeeswaran G. Biochemical properties of acetylcholine receptor subunits from Torpedo californica. Biochemistry, 1979, 18: 4465-4470 
4 Raftery MA, Hunskappiler MW, Stradler CD, Hood LE. acetylcholine receptor: complex of homologous subunits. Science, 1980, 208: 1454-1457

5 Kubalek E, Ralston S, Lindstrom J, Unwin N. Localization of subunits within the acetylcholine receptor by electron image analysis of tubular crystals from Torpedo marmorata. J Cell Biol, 1987, 105: 9-18

6 Tzartos SJ, Lindstrom JM. Monoclonal antibodies used to probe acetylcholine receptor structure: localization of the main immunogenic region and detection of similarities between subunits. Proc Natl Acad Sci USA, 1980, 77: 755-759

7 Tzartos SJ, Seybold ME, Lindstrom JM. Specificities of antibodies to acetylcholine receptors in sera from myasthenia gravis patients measured by monoclonal antibodies. Proc Natl Acad Sci USA, 1982, 79: 188-192

8 Tzartos S, Barkas T, Cung M, Mamalaki A, Marraud M, Papanastasiou D, Sakarellos C, Sakarellos-Daitsiotis M, Tsantili P, Tsikaris V. Anatomy of the antigenic structure of a large membrane autoantigen, the muscle-type nicotinic acetylcholine receptor. Immunol Rev, 1998, 163: 89-120

9 Barkas T, Mauron A, Roth B, Alliod C, Tzartos S, Ballivet M. Mapping of the main immunogenic region and toxin binding site of the nicotinic acetylcholine receptor. Science, 1987, 235: 77-80

10 Barkas T, Gabriel J-M, Mauron A, Hughes G, Roth B, Alliod C, Tzartos S, Ballivet M. Monoclonal antibodies to the main immunogenic region of the nicotinic acetylcholine receptor binds to residues 61-76 of the $\alpha$-subunit. J Biol Chem, 1988, 263: 5916-5920

11 Tzartos SJ, Kokla A, Walgrave S, Conti-Tronconi B. Localization of the main immunogenic region of the human muscle acetylcholine receptor to residues 67-76 of the $\alpha$-subunit. Proc Natl Acad Sci USA, 1988, 85: 2899-2903

12 Toyka KV, Drachman DB, Pestronk A, Kao I. Myasthenia gravis: Passive transfer from man to mouse. Science, 1975, 190: 397-399

13 Richman DP, Gomez CM, Berman PW, Burres SA, Fitch FW, Arnason BG. Monoclonal anti-acetylcholine receptor antibodies can cause experimental myasthenia. Nature, 1980, 286: 738-739 
14 Gomez CM, Richman DP. Monoclonal anti-acetylcholine receptor antibodies with differing capacities to induce experimental autoimmune myasthenia gravis. $J$ Immunol, 1983, 135: 234-241

15 Tzartos SJ, Hochschwender S, Vasquez P, Lindstrom J. Passive transfer of experimental autoimmune myasthenia gravis by monoclonal antibodies to the main immunogenic region of the acetylcholine receptor. J Neuroimmunol, 1987, 15: 185194

16 Tzartos SJ, Starzinski-Powitz A. Decrease in acetylcholine-receptor content of human myotube cultures mediated by monoclonal antibodies to $\alpha, \beta$ and $\gamma$ subunits. FEBS Lett. 1986, 196: 91-95

17 Graus Y, Meng F, Vincent A, van Breda Vriesman P, de Baets M. Sequence analysis of anti-AChR antibodies in experimental autoimmune myasthenia gravis. $J$ Immunol, 1995, 154: 6382-6396

18 Kohler G, Milstein C. Continuous cultures of fused cells secreting antibody of predefined specificity. Nature, 1975, 256: 495-497

19 Kordossi AA, Tzartos SJ. Monoclonal antibodies against the main immunogenic region of the acetylcholine receptor: mapping on the intact molecule. $J$ Neuroimmunol, 1989, 23: 35-40

20 Kordossi A Tzartos SJ. Conformation of cytoplasmic segments of acetylcholine receptor alpha- and beta-subunits probed by monoclonal antibodies: sensitivity of the antibody competition approach. EMBO J, 1987, 6: 1605-1610

21 Graus Y, Verschuuren F, Spaans F, Jennekens P, van Breda Vriesman P, de Baets M. Age-related resistance to experimental autoimmune myasthenia gravis in rats. $J$ Immunol, 1993, 150: 4093-4103

22 Lennon V, Lindstrom J, Seybold M. Experimental autoimmune myasthenia: a model of myasthenia gravis in rats and guinea pigs. J Exp Med, 1975, 141: 1365-1375

23 Lindstrom JM, Einarson BL, Lennon VA, Seybold ME. Pathological mechanisms in experimental autoimmune myasthenia gravis. I. Immunogenicity of syngeneic acetylcholine receptor and quantitative extraction of receptor and antibody-receptor complexes from muscles of rats with experimental autoimmune myasthenia gravis. $J$ Exp Med, 1976, 144: 726-738 
24 Verschuuren F, Graus Y, Theunissen R, Yamamoto T, Vincent A, van Breda Vriesman P, de Baets M. Role of acetylcholine receptor antibody complexes in muscle in experimental autoimmune myasthenia gravis. J Neuroimmunol, 1992, 36: $117-125$

25 Orlandi R, Gussow D, Jones P, Winter G. Cloning immunoglobulin variable domains for expression by the polymerase chain reaction. Proc Natl Acad Sci USA, 1989, 86: 3833-3837

26 Kabat E, Wu T, Perry H, Gottesman K, Foeller C. Sequences of proteins of immunological interest. $5^{\text {th }}$ ed, No 91-3242. National Institute of Health, Bethesda, MD. 1991

27 Sanger F, Nicklen S, Coulson AR. DNA sequencing with chain-terminating inhibitors. Proc Natl Acad Sci USA, 1977, 74: 5463-5467

28 Clarke S, Huppi K, Ruezinsky D, Stault L, Gerhard W, Weigert M. Inter- and intraclonal diversity in the antibody response to influenza hemagglutinin. $J \operatorname{Exp} M e d$, 1985, 161: 687-704

29 Sakano H, Maki R, Kurosawa Y, Roeder W, Tonegawa S. Two types of somatic recombination are necessary for the generation of complete immunoglobulin heavychain genes. Nature, 1980, 286: 676-683

30 Chukwuocha RU, Hartman AB, Feeney AJ. Sequences of four new members of the VH7183 gene family in BALB/c mice. Immunogenetics, 1994, 40: 76-78

31 Lawler A, Lin P, Gearhart P. Adult B-cell repertoire is biased toward two heavychain variable-region genes that rearrange frequently in fetal pre-B cells. Proc Natl Acad Sci USA, 1987, 84: 2454-2458

32 Sakano H, Huppi K, Heinrich G, Tonegawa S. Sequences at the somatic recombination sites of immunoglobulin light-chain genes. Nature, 1979, 280: 288-294

33 Christadoss P. Immunogenetics of experimental autoimmune myasthenia gravis. $C R C$ Crit Rev Immunol, 1989, 9: 247-278

34 Lennon V, Lambert E. Myasthenia gravis induced by monoclonal antibodies to acetylcholine receptor. Nature, 1980, 285: 238-240

35 Fishbach M, Lindstrom J, Talal N. Antibodies to polyadenylic acid in patients with myasthenia gravis. Clin Exp Immunol, 1981, 43: 73-79 
36 Beroukhim R, Unwin N. Three-dimensional location of the main immunogenic region of the acetylcholine receptor. Neuron, 1995, 15: 323-331

37 Andria M, Levy S, Benjamini E. Diverse VH and VL genes are used to produce antibodies against a defined protein epitope. J Immunol, 1990, 144: 2614-2619 


\title{
Chapter 3
}

\section{Epitope mapping and sequence analysis of monoclonal antibodies directed against the $\alpha$-bungarotoxin binding site of acetylcholine receptor}

\begin{abstract}
Myasthenia gravis (MG) is an antibody-mediated autoimmune disease. The binding of antibodies to acetylcholine receptor (AChR) results in AChR loss and leads to muscular weakness. The pathogenic anti-AChR antibodies are mainly found to be those that are directed against the main immunogenic region (MIR) on $\alpha$-subunit ( $\alpha 67-76)$ of AChR. However, the antibodies to the $\alpha$-bungarotoxin $(\alpha-\mathrm{BT})$ binding site on $\alpha$-subunit $(\alpha 189-$ 199) of AChR may contribute to the clinical signs in some MG patients. In the present study, three anti- $\alpha-B$ T binding site monoclonal antibodies (mAbs) were investigated on their epitope specificity and their nucleotide and deduced amino acid sequences of variable regions. The three mAbs recognized the same epitope on AChR as showed in a competitive inhibition assay between individual mAbs. The sequence analysis of the mAbs showed that they all utilized the same $\mathrm{VH}$ gene derived from mouse Q52 germline family, but different VL genes, indicating that the heavy chain play more important role in binding to AChR. Comparison of sequences between the anti- $\alpha$-BT binding site mAbs and the pathogenic anti-MIR mAb revealed that a large diversity was observed in both overall sequences and complementarity determining regions (CDRs).
\end{abstract}




\section{Introduction}

The major characteristic of myasthenia gravis (MG), an autoimmune disease, is the production of autoantibodies directed against the acetylcholine receptor (AChR) on postsynaptic membrane in neuromuscular junction[1-3]. The binding of anti-AChR antibodies to AChR results in AChR loss and leads to fatigability and weakness of skeletal muscle[4]. MG can be induced in animal model, the experimental autoimmune myasthenia gravis (EAMG), by immunization of purified AChR or passive transfer of anti-AChR antibodies[5-8]. The main mechanisms of pathogenesis of MG and EAMG are that the cross-linking of adjacent $\mathrm{AChR}$ molecules by anti-AChR antibodies causes an increase in the rate of internalization and degeneration of $\mathrm{AChR}$ [9-11], or that the binding of anti-AChR antibodies to AChR activate complement cascade leading to focal lysis of postsynaptic membrane[8]. However, the blocking anti-AChR antibodies by binding to acetylcholine (ACh) or $\alpha$-bungarotoxin ( $\alpha$-BT) binding site[12-16] may contribute to the pathogenesis in some cases of MG.

The AChR is well characterized autoantigen[17]. The binding site of $\alpha$-BT is demonstrated at residues $189-199$ of $\alpha$-subunit $[18,19]$ which overlaps the ACh binding site. Although about $65 \%$ of the antibodies in the sera of MG patients are directed against the main immunogenic region (MIR, $\alpha 67-76$ )[20-22], blocking antibodies may make up $0-33 \%$ of the total anti-AChR antibodies in MG patient sera[23]. Therefore, the knowledge of specificity and molecular structure of blocking antibodies is also a key question in understanding the pathogenesis of MG. In this study, a panel of 3 anti- $\alpha-B T$ binding site monoclonal antibodies (mAbs) made from mice immunized with purified Torpedo AChR (tAChR) were investigated on their epitope mapping and on their variable region sequences amplified from hybridoma cDNA. The sequences of anti- $\alpha-\mathrm{BT}$ binding site mAbs were compared with pathogenic anti-MIR mAb[24]. 


\section{Materials and methods}

\section{Production of anti-AChR mAbs}

Hybridomas were made from C57bl/6 mice immunized with tAChR purified from electric organ of Torpedo californica (Pacific Biomarine, California, USA) by affinity chromatography on Naja naja siamensis toxin (Miami Serpentaricem, Florida, USA) linked to Sepharose-4B (Pharmacia LKB, Woerden, The Netherlands) according to Kohler and Milstein[25]. MAbs were initially screened for reactivity to AChR by ELISA as described previously in Chapter 1.

\section{Specificity of anti- $\alpha-B T$ binding site $m A b s$}

MAbs A62, A64, and A65 were tested for their ability to inhibit the binding of ${ }^{125} \mathrm{I}-\alpha-\mathrm{BT}$ to AChR as previously described in Chapter 1 . The mAbs with more than $50 \%$ inhibition of ${ }^{125} \mathrm{I}-\alpha-\mathrm{BT}$ to AChR were considered as anti- $\alpha-\mathrm{BT}$ binding site mAbs.

\section{Epitope mapping of anti- $\alpha$-BT binding site $m A b s$}

The epitope mapping of anti- $\alpha$-BT binding site mAbs was performed by competitive inhibition between individual anti- $\alpha-\mathrm{BT}$ binding site $\mathrm{mAbs}$ for binding to tAChR according to Roberts et al[26]. Briefly, 96-well microtiter plates were coated with $50 \mu 1$ of $5 \mu \mathrm{g} / \mathrm{ml}$ tAChR for $1 \mathrm{~h}$ at $37{ }^{\circ} \mathrm{C}$, preincubated with PBS containing $0.5 \%$ BSA and $0.5 \%$ Tween-20, and incubated with $50 \mu \mathrm{l}$ of anti- $\alpha$-BT binding site mAbs $(0.08-10$ $\mu \mathrm{g} / \mathrm{ml}$ ) overnight at $4{ }^{\circ} \mathrm{C}$. Subsequently, $50 \mu \mathrm{l}$ of ${ }^{125} \mathrm{I}$-anti- $\alpha$-BT binding site mAbs, previously determined to give $50 \%$ of the maximum binding to tAChR, was added without washing and incubated for $1 \mathrm{~h}$ at room temperature. Plates were washed, and bound radioactivity was counted. The percentage of inhibition between ${ }^{125} \mathrm{I}$-anti- $\alpha$-BT binding site mAbs and unlabeled anti- $\alpha-\mathrm{BT}$ binding site mAbs was calculated as follows: $100 \times\left[\right.$ (average cpm of duplicate wells with ${ }^{125} \mathrm{I}$-anti- $\alpha$-BT binding site mAb alone - 
average cpm of duplicate wells with ${ }^{125} \mathrm{I}$-anti- $\alpha$-BT binding site mAb in the presence of unlabeled putative inhibitor anti- $\alpha$-BT binding site mAb) / average cpm of duplicate wells with ${ }^{125} \mathrm{I}$-anti- $\alpha$-BT binding site $\mathrm{mAb}$ alone]. Inhibition of ${ }^{125} \mathrm{I}$-anti- $\alpha$-BT binding site $\mathrm{mAb}$ by control monoclonal and polyclonal antibodies never exceeded $15 \%$, therefore, $0-25 \%$ inhibition was considered nonspecific.

\section{Cloning and sequencing of anti- $\alpha-B T$ binding site $m A b s$}

Total RNA was isolated from 1-5 x $10^{6}$ hybridoma cells secreting the mAbs using RNAzol (Cinna/Biotecx Laboratories Inc, Houston TX, USA). Oligo dT primed first strand cDNA was synthesized using AMV reverse transcriptase (Promega,USA) and used as a template for PCR amplification. The upstream primers used for heavy $(\mathrm{H})$ and light (L) chain variable region (V) sequence amplification are based on a consensus sequence of the first 8 codons of the VH and VL domains according to Orlandi et al[27] and Kabat et al[28] with minor modification. The downstream primer for the VH is complementary to codons $120-126$ within the $\mathrm{CH} 1$ domain of all $\mathrm{IgG}$ subclasses. The downstream primer for the VL is complementary to codons $114-122$ of the $\mathrm{C} \kappa$ domain. The complete sequences of primers are: VH upstream: 5' gg gaattc (gc)ag gt(gc) (ac)a(ag) ct(gt) cag (gc)ag tc(at) gg, CH1 downstream: 5' gg ggatcc agg ggc cag tgg ata ga(tc) ag, VL upstream: 5' cct gaattc gac (ag) tt gt(gt) (ac)t(gc) acc ca(ag) (at)ct cc, CK downstream: 5' cct ggatcc act gga tgg tgg gaa gat gga tac. The sequences underlined are Eco R1 and Bam $\mathrm{H} 1$ recognition sites to facilitate the subsequent cloning. The PCR was run for 30 cycles with denaturation at $94{ }^{\circ} \mathrm{C}$ for $2 \mathrm{~min}$, annealing at $55^{\circ} \mathrm{C}$ for $1 \mathrm{~min}$, and extension at 72 ${ }^{\circ} \mathrm{C}$ for $1.5 \mathrm{~min}$ in each cycle on DNA Thermal Cycler 480 (Perkin Elmer Cetus). The PCR products of VH and VL were digested with Eco R1 and Bam $\mathrm{H} 1$ and purified from $1 \%$ agarose gel with Geneclean kit (BIO 101 Inc, La Jolla, CA, USA), and ligated onto plasmid Bluescript M13 SK (Stratagene, La Jolla, CA, USA). The recombinant plasmids were transferred into E coli DH5 $\alpha$ and analysed for an insert of the right size by digestion with Eco R1 and Bam H1. The dideoxy chain termination sequencing procedure was performed according to Sanger et al[29] using the Bluescript KS and SK primer sites and a T7 sequencing kit (Pharmacia, Woerden The Netherlands). Several independent clones 
and at least three different colonies of each $\mathrm{H}$ chain and $\mathrm{L}$ chain of each anti-AChR mAb were sequenced to confirm the determined VH and VL sequences.

Mutual homology of sequences at the nucleotide level between anti-AChR mAbs was determined both for the overall $\mathrm{VH}$ and VL regions and for the complementarity determining regions (CDRs) using the program DNAsis. Homology between anti-AChR mAbs and other antibodies in EMBL Data Library was performed by FASTA computer search. The sequences of VH and VL of mAbs A62, A64, and A65 have been accepted by the EMBL Data Library as AC No (VH and VL): A62: X80952 and X80951, A64: X80948 and X80947, and A65: X80946 and X80945.

\section{Results}

Characteristics of anti- $\alpha-B T$ binding site $m A b s$

The isotype, specificity and cross-reactivity of anti- $\alpha-B$ T binding site mAbs A62, A64 and A65 were summarized in Table 1.

Table 1 Characteristics of anti- $\alpha$-BT binding site mAbs

\begin{tabular}{lllc}
$\mathrm{mAb}$ & isotype & specificity $^{\mathrm{a}}$ & $\mathrm{AChR}^{\mathrm{b}}$ \\
& & & \\
\hline $\mathrm{A} 62$ & $\mathrm{IgG} 2 \mathrm{~b}$ & $\alpha$-BT binding site & $\mathrm{T}$ \\
$\mathrm{A} 64$ & $\mathrm{IgG1}$ & $\alpha-\mathrm{BT}$ binding site & $\mathrm{T}$ \\
$\mathrm{A} 65$ & $\mathrm{IgG2b}$ & $\alpha$-BT binding site & $\mathrm{T}$ \\
\hline
\end{tabular}

\footnotetext{
${ }^{a}$ MAbs able to block the binding of $\alpha$-bungarotoxin to AChR.

${ }^{\mathrm{b}}$ Reactivity of mAbs with AChR from Torpedo (T).
} 


\section{Epitope specificity of anti- $\alpha$-BT binding site $m A b s$}

Mutual inhibition experiments between anti- $\alpha$-BT binding site mAbs elicited against tAChR demonstrated that mAbs A62 and A65 recognized the same or overlapping epitopes. MAb A64 probably recognized the same as mAbs A62 and A65 but with higher affinity (Figure 1).
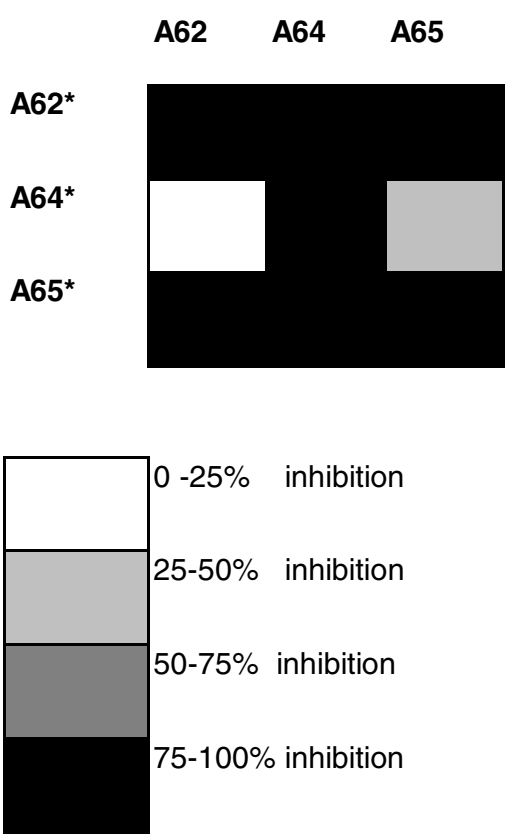

* ${ }^{125}$ I-mAbs

Figure 1 Epitope mapping of anti- $\alpha$-BT binding site mAbs. Epitope specificity of anti- $\alpha$-BT binding site mAbs was defined by mutual inhibition between mAbs for binding to AChR. The binding of ${ }^{125} \mathrm{I}-\mathrm{mAb}$ (50\% of maximum binding) was inhibited with $0.08-10 \mu \mathrm{g} / \mathrm{ml}$ of unlabeled competitor $\mathrm{mAb}$. The results in this figure represent the percentage of inhibition at $2 \mu \mathrm{g} / \mathrm{ml}$ unlabeled competitor. 
Genetic features of anti- $\alpha$-BT binding site $m A b s$

All $\mathrm{H}$ chain variable region genes of anti- $\alpha$-BT binding site mAbs A62, A64 and A65 are $339 \mathrm{bp}$ in length (the first $24 \mathrm{bp}$ in VH upstream primer not included), encoding 113 amino acids and determining the codons 9-113 of VH (Figure 2A). All the three mAbs use a VH gene derived from mouse germline family Q52 (EMBL Data Library, AC No M24271), associated with D and JH4[30].

The $\mathrm{L}$ chain variable region gene of anti- $\alpha-\mathrm{BT}$ binding site mAb A62 is $306 \mathrm{bp}$ in length (the first $24 \mathrm{bp}$ in VL upstream primer not included), encoding 102 amino acids and determining the codons 9-107 of VL (Figure 2B). MAb A62 uses a VL gene being a member of mouse subgroup $V \kappa 3$ joined with $\mathrm{J}_{\kappa} 1$ segment[31]. The $\mathrm{L}$ chain variable region gene of mAbs A64 and A65 have extra 2 amino acids with one in CDR1 and one in CDR3 as compared with mAb A62. The VL gene used by mAbs A64 and A65 is a member of mouse $\mathrm{V} \kappa 2$ subgroup and also associated with $\mathrm{J} \kappa 1$ segment.

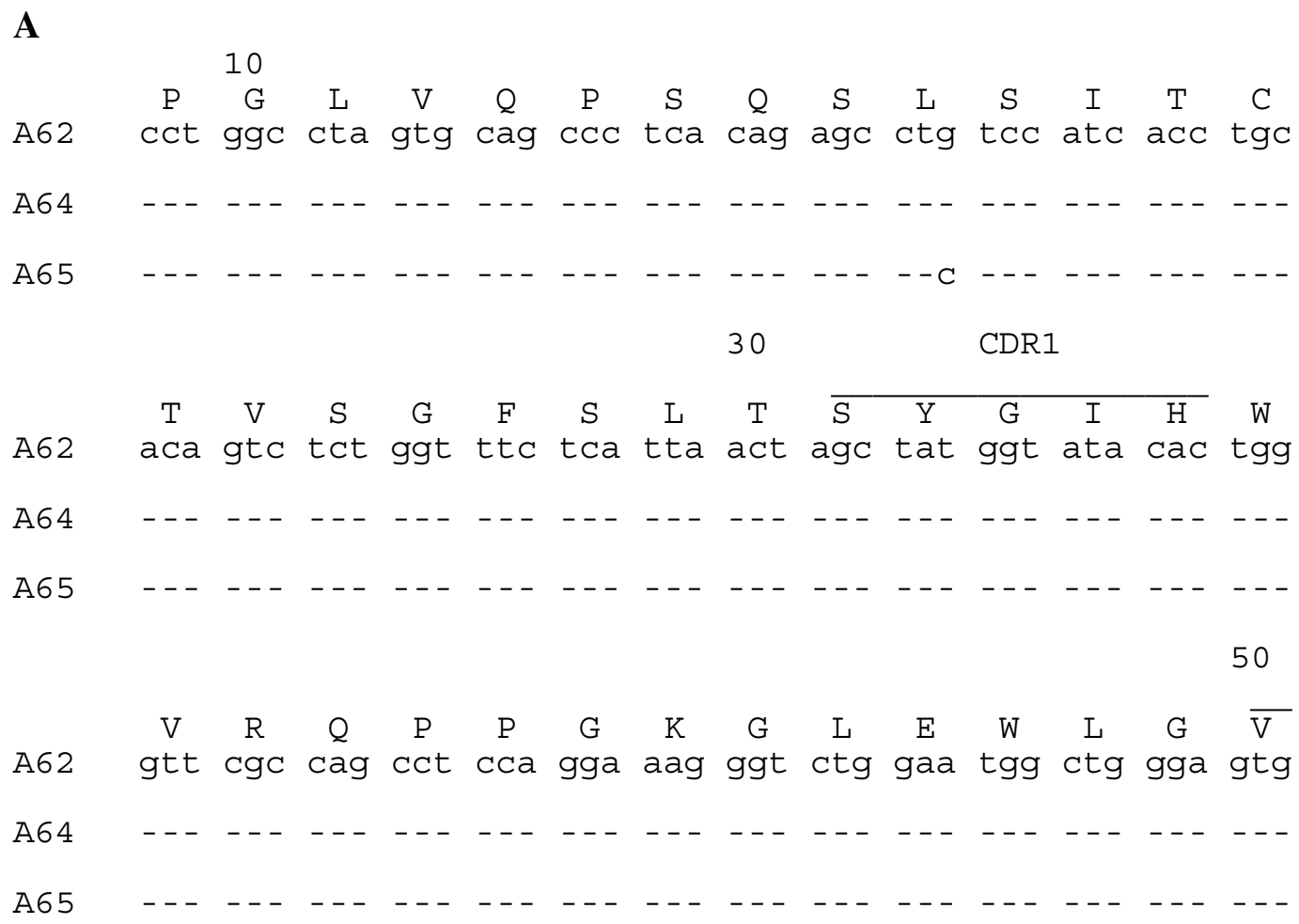


CDR2

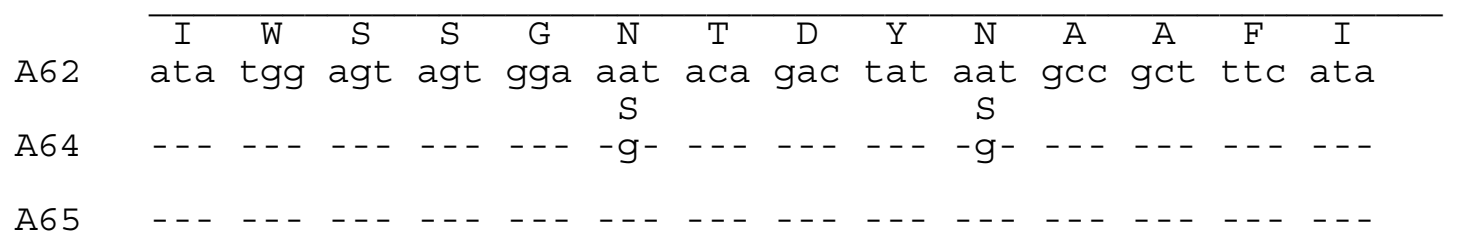

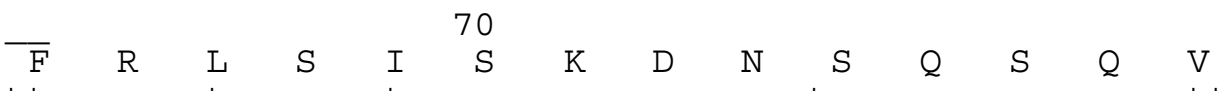

A62 ttc aga ctg agc atc agc aag gac aac tcc cag agc caa gtt

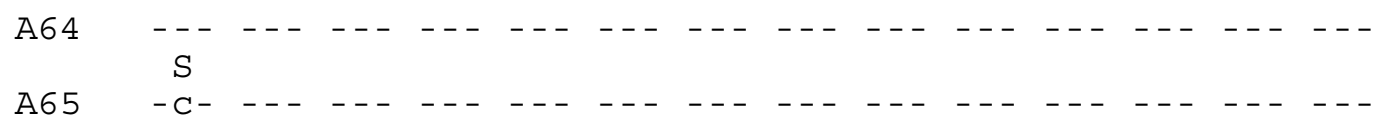

$\begin{array}{lllllllllllllllllllllllll}\mathrm{F} & \mathrm{F} & \mathrm{K} & \mathrm{M} & \mathrm{N} & \mathrm{S} & \mathrm{L} & \mathrm{Q} & \mathrm{A} & \mathrm{D} & \mathrm{D} & \mathrm{T} & \mathrm{A} & \mathrm{I}\end{array}$

A62 ttc tt aaa atg aac agt ctg caa gct gat gac act gcc ata

A64

A65

90

CDR3

$\begin{array}{llllllllllllll} & \mathrm{F} & \mathrm{C} & \mathrm{V} & \mathrm{K} & \mathrm{N} & \mathrm{F} & \mathrm{H} & \mathrm{F} & \mathrm{Y} & \mathrm{G} & \mathrm{T} & \mathrm{G} & \mathrm{Y}\end{array}$

A62 tac ttc tgt gtc aaa aat tt cat ttc tac ggt act ggt tat

A64 -. - - - - - - -

A65

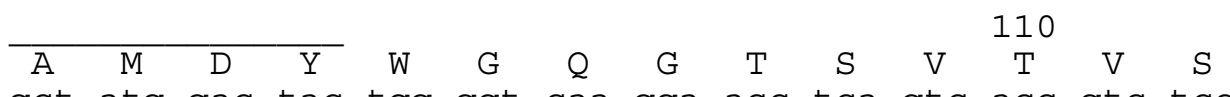

A62 get atg gac tac tgg ggt caa gga acc tca gtc acc gtc tcc

A64

A65

A62 tca

A64

A65 
$\mathbf{B}$

$\begin{array}{llllllllllll}10 & & & & & & & & & & & \end{array}$

A62 gct tcc tta get gta tct ctg ggg cag agg gcc acc atc tca

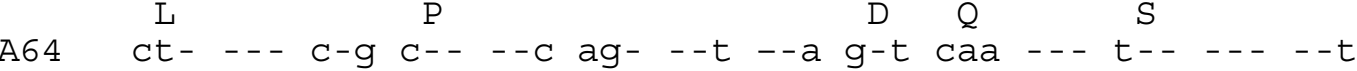

A65

CDR1

30

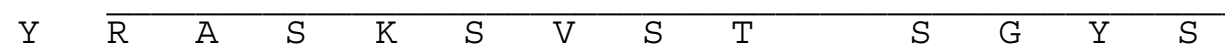

A62 tac agg gcc agc aaa agt gtc agt aca tct ggc tat agt $\begin{array}{lllllllllll}C & S & Q & \mathrm{~L} & \mathrm{~V} & \mathrm{H} & \mathrm{S} & \mathrm{Y} & \mathrm{N} & \mathrm{T}\end{array}$

A64 -g- - -a t-t --t c-g - - c c-t gta cac agt $-a---a$ a-c $-c c$

A65

\begin{tabular}{llllllllllllllll}
\hline $\mathrm{Y}$ & $\mathrm{M}$ & $\mathrm{H}$ & $\mathrm{W}$ & $\mathrm{N}$ & $\mathrm{Q}$ & $\mathrm{Q}$ & $\mathrm{K}$ & $\mathrm{P}$ & $\mathrm{G}$ & $\mathrm{Q}$ & $\mathrm{P}$ & $\mathrm{P}$ & $\mathrm{R}$
\end{tabular}

A62 tat atg cac tgg aac caa cag aaa cca gga cag cca ccc aga

A64 - - t-a --t - - t-- -tg - - - -

A65

50

CDR2

$\begin{array}{llllllllllllllllll}\mathrm{L} & \mathrm{L} & \mathrm{I} & \mathrm{Y} & \mathrm{L} & \mathrm{V} & \mathrm{S} & \mathrm{N} & \mathrm{L} & \mathrm{E} & \mathrm{S} & \mathrm{G} & \mathrm{V} & \mathrm{L}\end{array}$ A62 ctc ctc atc tat ctt gta tcc aac cta gaa tct ggg gtc ctg

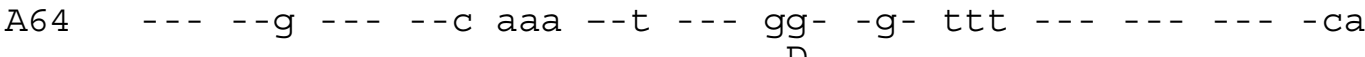
A 65

$\begin{array}{lllllllllllllll}P & R & F & S & G & S & G & S & G & T & D & F & T & L\end{array}$ A62 cca agg ttc agt ggc agt ggg tct ggg aca gac ttc acc ctc

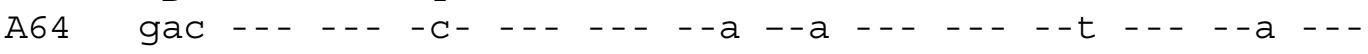

A65 


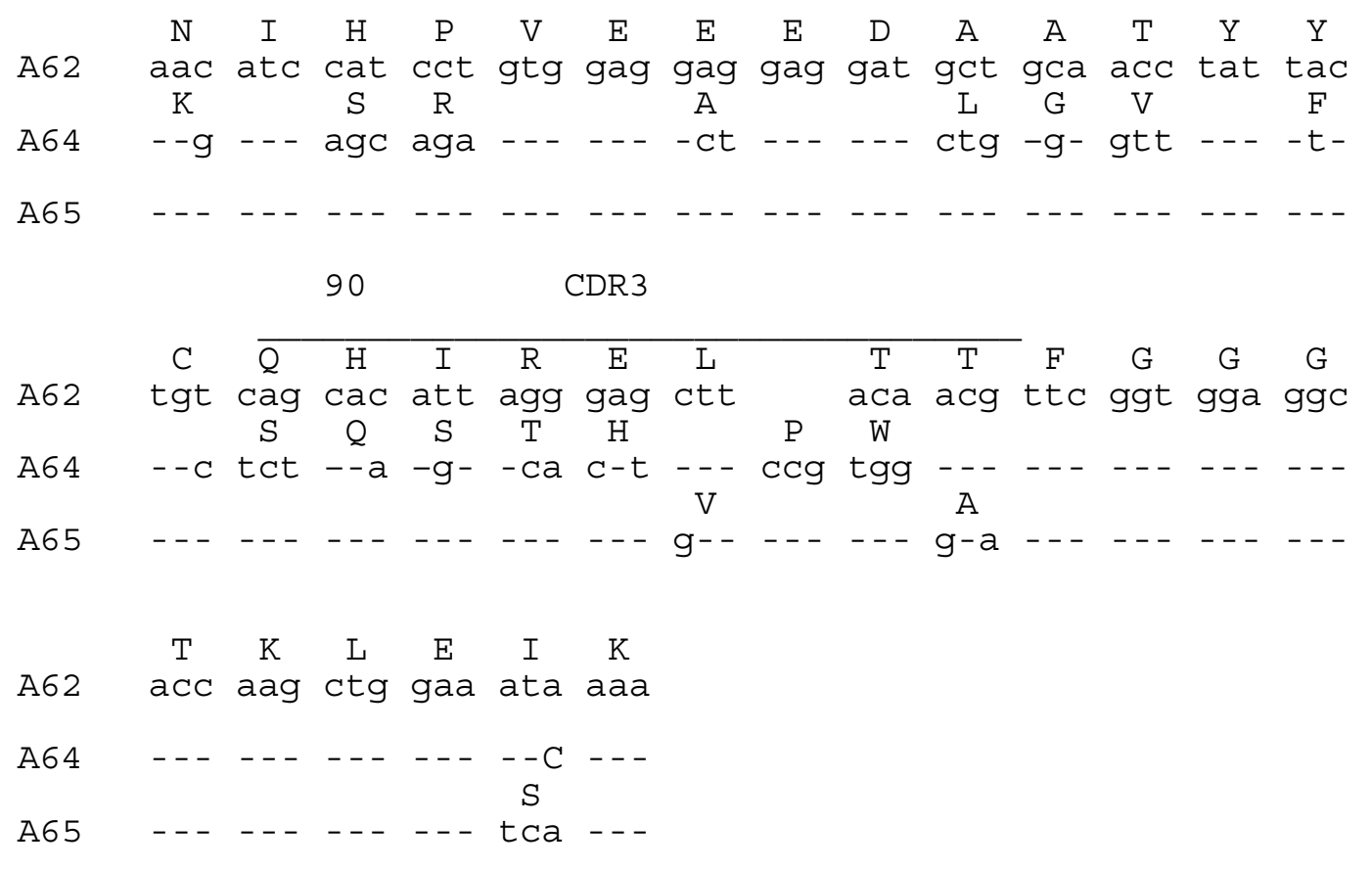

Figure 2 Sequence comparison of anti- $\alpha-B T$ binding site mAbs. Sequences of anti- $\alpha-B T$ binding site mAbs are compared for the heavy chain (A) and light chain (B). The complete nucleotide sequences and deduced amino acid sequences are aligned starting from codon 9 as numbered according to Kabat et al[28]. Sequence identity of anti- $\alpha$-BT binding site mAbs with mAb A62 or with A64 (A65 was compared with A64 in light chain) is indicated by dashes. Complementarity determining regions (CDRs) are also indicated.

\section{Discussion}

The clinical signs and symptoms in MG result from loss of functional AChR which is entirely antibody-mediated[4]. The pathogenic anti-AChR antibodies are mainly found to be those that are directed against a region on the $\alpha$-subunit of AChR ( $\alpha 67-76)$, MIR[32]. However, antibodies to the cholinergic and neurotoxin binding sites may contribute to the clinical signs in some MG patients[33, 34]. Therefore, the understanding of contribution of individual anti- $\alpha$-BT binding site antibodies to AChR loss is also important in the pathogenesis of MG. Unfortunately, since the anti- $\alpha-B T$ binding site mAbs obtained 
from mice immunized with tAChR were not able to cross-react with mammalian AChR (rat or mouse AChR), we could not investigate the pathogenicity of the mAbs in vivo by passive transfer of the mAbs into rats or mice. However, the epitope mapping and the comparison of sequences among the anti- $\alpha-\mathrm{BT}$ binding site mAbs and between the mAbs and pathogenic anti-MIR mAb revealed some important features.

The $\mathrm{H}$ chain sequence of variable region of mAb A62 shows a 99.4\% homology at the nucleotide level as compared with mAb A64. Two nucleotide difference are identified. Both appear in CDR2 and lead to amino acid changes (in codons 56 and 60, Asn and Asn in A62, whereas Ser and Ser in A64). MAbs A62 and A65 almost share an identical $\mathrm{H}$ chain at the amino acid level with only one amino acid substitution in CDR2 (a Phe in A62 and a Ser in A65 in codon 65). The overall sequence homology of $\mathrm{H}$ chain between mAbs A64 and A65 is $98.8 \%$ with 3 amino acid differences in CDR2. The L chain sequence of variable region of mAb A62 shows a $65.2 \%$ and $64.3 \%$ homology respectively at the nucleotide level as compared with mAbs A64 and A65, since they are derived from different mouse subgroup genes. However, the homology of L chain between mAbs 64 and A65 is 97.8\% with 7 nucleotide substitutions. One occurs in codon 53 within CDR2 and leads to amino acid change (Gly in A64 and Asp in A65). Three appear in 2 codons of CDR3 (codons 94 and 97, Leu and Thr in A64, whereas Val and Ala in A65).

The epitope mapping of the anti- $\alpha$-BT binding site mAbs shows that mAbs A62 and A65 recognize the same epitope. The analysis of gene utilization of the mAbs indicates that the $\mathrm{H}$ chain of A62 and A65 are derived from the same mouse germline family. The substitutions in CDR2 between the mAbs A62 and A65 (Phe $\rightarrow$ Ser) did not lead to specificity change. By contrast, the L chains of both mAbs A62 and A65 belong to different mouse subgroup and express only $46.7 \%, 57.1 \%$ and $47.8 \%$ homology at nucleotide level in CDR1, 2 and 3 respectively, suggesting that the $H$ chain play more important role in binding to AChR. MAbs A64 and A65 are likely to be derived from the same germline gene but undergone limited somatic mutation driven by antigen AChR. The conserved substitutions in CDR2 of $\mathrm{H}$ chain between A64 and A65 probably did not influence the antibody specificity. However, the substitutions in CDR2 and CDR3 of L chain seem to determine the higher affinity of mAb A64 to AChR. 
Alignment of sequence of the anti- $\alpha$-BT binding site mAbs with that of pathogenic anti-MIR mAb A7 (see Chapter 2) reveals a large sequence diversity. MAb A7 shows only a $63.7 \%, 64.0 \%$ and $63.4 \%$ overall sequence homology in $\mathrm{H}$ chains and a 97.0\%, 64.7\% and 64.1\% in $\mathrm{L}$ chains with mAbs A62, A64 and A65 respectively. Furthermore, the homology in CDRs of both $\mathrm{H}$ and $\mathrm{L}$ chains is all below $40 \%$ at amino acid level (except A62 L chain). Despite the highly homologous L chains used by mAbs A7 and A62, the quite diverse $\mathrm{H}$ chains determine the different specificities of the mAbs.

In conclusion, sequence analysis of anti- $\alpha$-BT binding site mAbs shows that the VH genes utilized are related to Q52 germline family, and a large sequence diversity is found between the anti- $\alpha-\mathrm{BT}$ binding site $\mathrm{mAbs}$ and the pathogenic anti-MIR mAb.

\section{Acknowledgements}

We are grateful to R. Aarts for technical assistance. This work was supported by grants from Het Prinses Beatrix Fonds and L'Association Francaise contre les Myopathies.

\section{References}

1 Lindstrom J, Shelton D, Fujii Y. Myasthenia gravis. Adv Immunol, 1988, 42: 233-284

2 Graus Y, de Baets M. Myasthenia gravis: an autoimmune response against the acetylcholine receptor. Immunol Res, 1993, 12: 78-100

3 Vincent A. Aetiological factors in development of myasthenia gravis. Adv Neuroimmunol, 1994, 4: 355-371

4 Drachman B. Myasthenia gravis. N Eng J Med, 1994, 330: 1797-1810

5 Toyka KV, Drachman DB, Pestronk A, Kao I. Myasthenia gravis: Passive transfer from man to mouse. Science, 1975, 190: 397-399 
6 Richman DP, Gomez CM, Berman PW, Burres SA, Fitch FW, Arnason BG. Monoclonal anti-acetylcholine receptor antibodies can cause experimental myasthenia. Nature, 1980, 286: 738-739

7 Gomez CM, Richman DP. Monoclonal anti-acetylcholine receptor antibodies with differing capacities to induce experimental autoimmune myasthenia gravis. $J$ Immunol, 1983, 135: 234-241

8 Tzartos SJ, Hochschwender S, Vasquez P, Lindstrom J. Passive transfer of experimental autoimmune myasthenia gravis by monoclonal antibodies to the main immunogenic region of the acetylcholine receptor. J Neuroimmunol, 1987, 15: 185194

9 Heinemann S, Bevan S, Kullberg R, Lindstrom J, Rice J. Modulation of the acetylcholine receptor by anti-receptor antibody. Proc Natl Acad Sci USA, 1977, 74: 3090-3094

10 Tzartos S, Barkas T, Cung M, Mamalaki A, Marraud M, Papanastasiou D, Sakarellos C, Sakarellos-Daitsiotis M, Tsantili P, Tsikaris V. Anatomy of the antigenic structure of a large membrane autoantigen, the muscle-type nicotinic acetylcholine receptor. Immunol Rev, 1998, 163: 89-120

11 Papanastasiou D, Mamalaki A, Eliopoulos E, Poulas K, Liolitsas C, Tzartos S. Construction and characterization of a humanized single chain Fv antibody fragment against the main immunogenic region of the acetylcholine receptor. $J$ Neuroimmunol, 1999, 94: 182-185

12 Gomez CM, Richman DP, Berman PW, Burries SA, Arnason BGW, Fitch FW. Monoclonal antibodies against purified nicotinic acetylcholine receptor. Biochem Biophys Res Commun, 1979, 88: 575-582

13 Watters D, Maelicke A. Organization of ligand binding sites at the acetylcholine receptor: A study with monoclonal antibodies. Biochemistry, 1983, 22: 1811-1819

14 Cleveland WL, Wasserman NH, Sarangarajan R, Penn AS, Erlanger BF. Monoclonal antibodies to the acetylcholine receptor by a normally functioning auto-anti-idiotypic mechanism. Nature, 1983, 305: 56-57

15 Whiting P, Vincent A, Newsom-Davis J. Monoclonal antibodies to Torpedo acetylcholine receptor. Characterization of antigenic determinants within the cholinergic binding site. Eur J Biochem, 1985, 150: 533-539 
16 Dowding AJ, Hall ZM. Monoclonal antibodies specific for each of the two toxinbinding sites of Torpedo acetylcholine receptor. Biochemistry, 1987, 26: 6372-6381

17 Conti-Tronconi B, Mclane K, Raftery M, Grando S, Protti M. The nicotinic acetylcholine receptor: structure and autoimmune pathology. Crit Rev Biochem Mol Biol, 1994, 29: 69-123

18 Tzartos SJ, Remoundos MS. Fine localization of the major $\alpha$-bungarotoxin binding site to residues $\alpha$ 185-195 of the acetylcholine receptor. Residues 189, 190, and 195 are indispensable for binding. J Biol Chem, 1990, 265: 21462-21467

19 Griesmann GE, McCormick DJ, De Aizpurua HJ, Lennon VA. $\alpha$-bungarotoxin binding to human acetylcholine receptor $\alpha$-subunit peptide 185-199 in solution and solid phase but not to peptide 125-147 and 389-409. J Neurochem, 1990, 54: 15411547

20 Tzartos SJ, Seybold ME, Lindstrom JM. Specificities of antibodies to acetylcholine receptors in sera from myasthenia gravis patients measured by monoclonal antibodies. Proc Natl Acad Sci USA, 1982, 79: 188-192

21 Tzartos SJ, Sophianos D, Efthimiadis A. Role of the main immunogenic region of AChR in MG. An Fab monoclonal antibody protects against antigenic modulation by human sera. J Immunol, 1985, 134: 2343-2349

22 Heidenreich F, Vincent A, Newsom-Davis J. Differences in fine specificity of antiacetylcholine receptor antibodies between subgroups of spontaneous myasthenia gravis of recent onset, and of penicillamine induced myasthenia. Autoimmunity, 1988, 2: $31-37$

23 Whiting P, Vincent A, Newsom-Davis J. Acetylcholine receptor antibody characteristics in myasthenia gravis. Fractionation of $\alpha$-bungarotoxin binding site antibodies and their relationship to IgG subclass. J Neurol, 1983, 5: 1-9

24 Graus Y, Meng F, Vincent A, van Breda Vriesman P, de Baets M. Sequence analysis of anti-AChR antibodies in experimental autoimmune myasthenia gravis. J Immunol, 1995, 154: 6382-6396

25 Kohler G, Milstein C. Continuous cultures of fused cells secreting antibody of predefined specificity. Nature, 1975, 256: 495-497 
26 Roberts A, Lang B, Vincent A, Newsom-Davis J. Search for cross-reactive idiotypes on monoclonal and myasthenia gravis acetylcholine receptor antibodies. Autoimmunity, 1992, 12: 53-60

27 Orlandi R, Gussow D, Jones P, Winter G. Cloning immunoglobulin variable domains for expression by the polymerase chain reaction. Proc Natl Acad Sci USA, 1989, 86: 3833-3837

28 Kabat E, Wu T, Perry H, Gottesman K, Foeller C. Sequences of proteins of immunological interest. $5^{\text {th }}$ ed, No 91-3242. National Institute of Health, Bethesda, MD. 1991

29 Sanger F, Nicklen S, Coulson AR. DNA sequencing with chain-terminating inhibitors. Proc Natl Acad Sci USA, 1977, 74: 5463-5467

30 Sakano H, Maki R, Kurosawa Y, Roeder W, Tonegawa S. Two types of somatic recombination are necessary for the generation of complete immunoglobulin heavychain genes. Nature, 1980, 286: 676-683

31 Sakano H, Huppi K, Heinrich G, Tonegawa S. Sequences at the somatic recombination sites of immunoglobulin light-chain genes. Nature, 1979, 280: 288294

32 Tzartos SJ, Kokla A, Walgrave S, Conti-Tronconi B. Localization of the main immunogenic region of the human muscle acetylcholine receptor to residues 67-76 of the $\alpha$-subunit. Proc Natl Acad Sci USA, 1988, 85: 2899-2903

33 Gomez C, Richman D. Anti-acetylcholine receptor antibodies directed against the $\alpha$ BT binding site induce an unique form of experimental myasthenia. Proc Natl Acad Sci USA, 1983, 80: 4089-4093

34 Conti-Tronconi B, Tang F, Diethelm B, Spencer S, Reinhardt-Maelicke S, Maelicke A. Mapping of a cholinergic binding site by means of synthetic peptides, monoclonal antibodies, and $\alpha$-BT. Biochemistry, 1990, 29: 6221-6230 


\title{
Chapter 4
}

\section{Construction and characterization of a single chain antibody fragment derived from thymus of a patient with myasthenia gravis}

\begin{abstract}
Pathogenic anti-acetylcholine receptor (AChR) antibodies in myasthenia gravis (MG) and its animal model experimental autoimmune myasthenia gravis (EAMG) are mainly those that are directed against the main immunogenic region (MIR) of AChR. Bivalent antiMIR antibodies binding to $\alpha$-subunits of AChR result in AChR loss by antigenic modulation and activation of complement. Monovalent Fab and single chain variable fragment $(\mathrm{ScFv})$ of pathogenic anti-AChR antibodies can prevent the pathogenic antibodies from binding to AChR. In the present study, a ScFv637 was constructed from its parental Fab637, previously isolated from thymus-derived phage display library with specificity of anti-MIR of human AChR (hAChR), by PCR amplification. PCR products of VH and VL genes of Fab637 were assembled into vector phagemid pHEN2 containing a GS rich linker and a c-myc tag and a 6x His tag at C-terminus for specific detection and for efficient purification. The recombinant pHEN2-ScFv637 construct was transformed into E coli HB2151 for soluble production of ScFv after induction with IPTG. ScFv637 was efficiently produced in periplasmic fraction but not in culture supernatant of bacteria as detected by nitrocellulose dot blot using mouse anti-c-myc monoclonal antibody (mAb). ScFv637 was able to bind to hAChR in standard precipitation radioimmunoassay (RIA). ScFv637 could also bind to monkey AChR in situ on monkey neuromuscular junction as showed in immunohistochemical staining. Furthermore, ScFv637 was capable of inhibiting the binding of its intact IgG637 and anti-MIR mAb35 to hAChR up to $32.9 \%$ and $73.0 \%$ respectively demonstrated in a competitive ELISA, and of MG patient sera from $27.8 \%$ to $45.5 \%$ in a competitive RIA. Therefore, ScFv637, easier for manipulation in improvement of affinity and stability compared with its parental Fab637, may serve as an alternative candidate for specific immunotherapy in MG.
\end{abstract}




\section{Introduction}

In the autoimmune disease myasthenia gravis (MG), the binding of autoantibodies to acetylcholine receptor (AChR) results in $\mathrm{AChR}$ loss and leads to fatigability and weakness of skeletal muscle[1-3]. Experimental autoimmune myasthenia gravis (EAMG), an animal model that closely resembles human MG, can be induced by active immunization of purified $\mathrm{AChR}$ or by passive transfer of polyclonal or monoclonal antibodies (mAbs) against AChR[4-6]. The AChR is well characterized autoantigen[7]. Muscle-type AChR in neuromuscular junction is a complex transmembrane glycoprotein and consists of five subunits of $\alpha_{2} \beta \gamma \delta[8-10]$. The $\mathrm{AChR}$ contains a characteristic region, termed the main immunogenic region (MIR) on the $\alpha$-subunit at residues 67-76[11-13] which is easily accessible in vivo to antibodies.

More than half of the autoantibodies in MG patients or EAMG rats were found to be directed against the MIR[14-16] and pathogenic mAbs were found exclusively among mAbs against MIR[6, 17, 18]. Anti-MIR antibodies are especially effective in antigenic modulation[19], a mechanism in which the binding of anti-AChR antibodies to AChR by cross-linking of adjacent AChR molecules results in accelerating AChR internalization. Furthermore, the binding of anti-MIR antibodies to AChR can also trigger the complement cascade leading to focal lysis of postsynaptic membrane[6].

The ideal immunosuppressive therapies for $\mathrm{MG}$ would be to eliminate the autoimmune response to $\mathrm{AChR}$ without affecting the immune response to other antigens. Several specific immunosuppressive therapies have been tested in EAMG based on the pathogenesis of MG including anti-idiotypic antibodies[20] and administration of AChR orally[21-23] or nasally[24-26]. Meanwhile, the development of a bioimmunological agent for specific treatment of MG patients has been the focus of many researches in MG. Fab and single chain variable fragment $(\mathrm{ScFv})$ of antibodies derived from anti-MIR antibodies can bind to AChR, blocking the binding of anti-MIR antibodies to AChR, but does not have the activity to induce antigenic modulation or complement reaction. Fab isolated from MG patient thymus[27, 28] and from rat anti-MIR mAbs[29, 30] or ScFv constructed from rat anti-MIR mAbs[31-33] could prevent anti-MIR mAbs or MG patient 
sera from binding to $\mathrm{AChR}$ or from inducing antigenic modulation in a cultured TE671 cell line.

In this study, an human ScFv637 directed against the MIR of human AChR (hAChR) was constructed from its parental Fab637, isolated from thymus-derived phage display library of a MG patient earlier in our laboratory[27]. ScFv637 derived from human does not possess immunogenicity for application in MG patients and easily undergoes genetic manipulation to improve its stability and affinity.

\section{Materials and methods}

\section{Anti-MIR Fab637}

Fab637 was isolated from the thymus of a patient with MG by phage display library using vector phagemid pComb3H, and panned on hAChR extracted from TE671 cell culture[34]. The reconstructed phagemid DNA was transformed into E coli XL1-blue for production of soluble Fab637 after last round of panning. Fab637 was able to bind hAChR in precipitation radioimmunoassay (RIA) and solid phase RIA (SPRIA)[27].

\section{Construction of ScFv637}

VH gene of ScFv637 was amplified from pComb3H-Fab637 by PCR using VH upstream primer 5' aa tctaga ccatg gcc gag gtg cag ctg ctg gag tct ggg (the sequences underlined are the recognition sites of endonucleases $\mathrm{XbaI}$ and $\mathrm{NcoI}$ respectively) encoding the first 8 amino acids of $\mathrm{VH}$ region, and $\mathrm{VH}$ downstream primer 5' at gaattc ctcga gga tga gac agt gac cag gg (underlined are EcoRI and XhoI sites respectively) complementary to the gene of amino acids 107-113. The VL gene of ScFv637 was amplified using VL upstream primer 5' aa tctaga gtgca ccc gag ctc act cag ccc (underlined are XbaI and ApaLI sites respectively) encoding the first 7 amino acids of VL region, and VL downstream primer 5' at gaattc gcggccgc tag gac ggt cag ctt gg (underlined are EcoRI and NotI sites respectively) complementary to the gene of amino acids 102-107. The PCR 
was performed for 35 cycles with denaturation at $95{ }^{\circ} \mathrm{C}$ for $1 \mathrm{~min}$, annealing at $50{ }^{\circ} \mathrm{C}$ for 1 min and extension at $72{ }^{\circ} \mathrm{C}$ for 2 min using high fidelity enzyme mix (Roche Diagnostics GmbH, Mannheim, Germany).

The VH and VL gene fragments were purified with QIAquick PCR Purification Kit (QIAGEN GmbH, Hilden, Germany). The purified VH gene fragments were first digested with NcoI and XhoI and 1\% agarose gel-purified with Geneclean Kit II (Bio 101 Inc, La Jolla, CA, USA), and cloned onto NcoI and XhoI site of vector pHEN2 (Figure 1; a generous gift of Dr G. Winter, Center for Protein Engineering, MRC Center, University of Cambridge, UK). The recombinant phagemid was transformed into competent E coli DH5 $\alpha$ and isolated and purified with Wizard Plus SV Minipreps (Promega, USA). The right insert was confirmed by digestion with the same endonucleases NcoI/XhoI. Subsequently, the purified VL gene fragments were digested with ApaLI/NotI, and cloned onto the pHEN2-VH as above to construct a complete ScFv637 gene segment. The ScFv637 was then transformed into E coli DH5 $\alpha$ and cloned and purified with QIAGEN Plasmid Midi Kit (QIAGEN GmbH, Hilden, Germany). The recombinant phagemid was digested with $\mathrm{NcoI} / \mathrm{XhoI}$ to confirm the right size of $\mathrm{VH}$ insert, with ApaLI/NotI to confirm the VL insert, and with NcoI/NotI to confirm the ScFv insert.

\section{A}

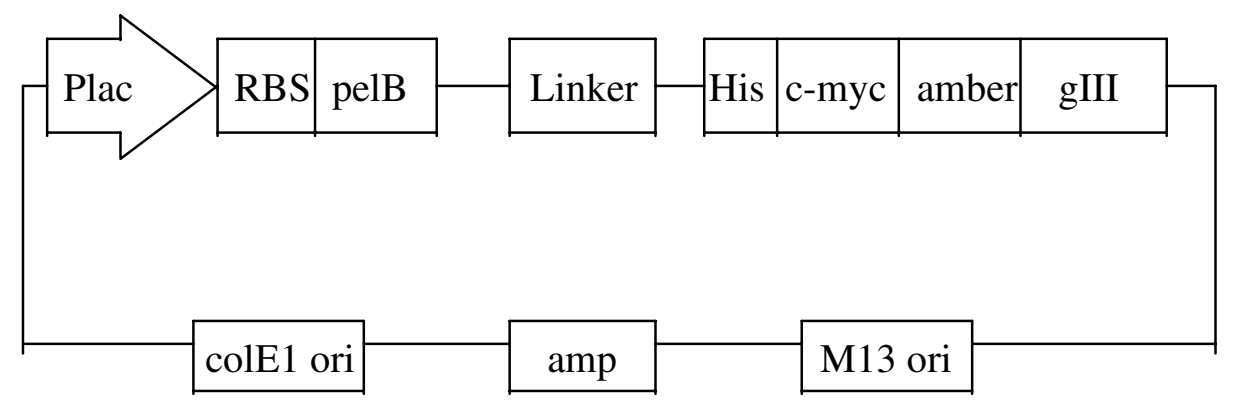


B

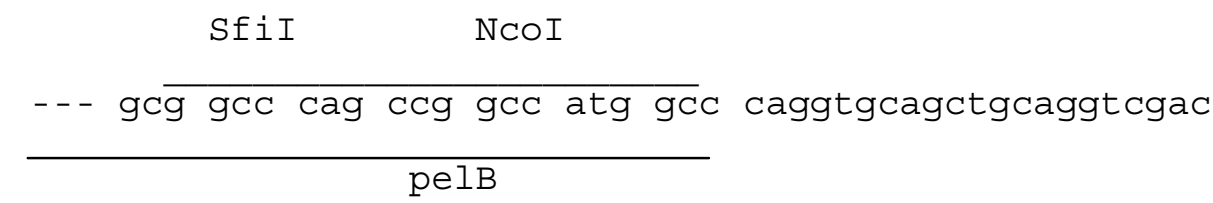

XhoI

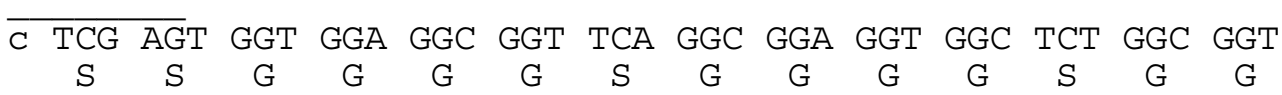

ApaLI NotI

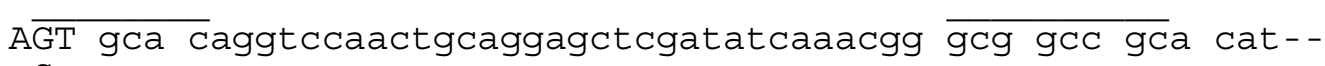
$\mathrm{S}$

His

Figure 1 Phagemid vector pHEN2 used for construction of single chain antibody fragment (ScFv). A: Structure of pHEN2. B: Sequence of cloning sites of pHEN2. Sequences underlined are part of pelB leader or $6 x$ His tag. Nucleotide sequence of linker is depicted in capital letters.

\section{DNA sequencing}

The sequencing reaction of purified pHEN2-ScFv637 was performed with dye terminator cycle sequencing method using Terminator Ready Reaction Mix (Perkin Elmer, ABI Prism, USA) in PCR at the conditions of denaturation at $96{ }^{\circ} \mathrm{C}$ for $30 \mathrm{sec}$, annealing at 50 ${ }^{\circ} \mathrm{C}$ for $15 \mathrm{sec}$, and extension at $60{ }^{\circ} \mathrm{C}$ for $4 \mathrm{~min}$. The primers $\mathrm{VH}$ upstream, $\mathrm{VH}$ downstream and VL upstream used in PCR amplification of VH and VL gene fragments above were used as sequencing primers. The PCR was run for 26 cycles in a total volume of $20 \mu \mathrm{l}$. The PCR products were purified with Edge Gel Filtration Cartriges (Edge BioSystems, USA) and sequenced on ABI Prism 310 Genetic Analyzer (PE BioSystems, USA). 
Production of soluble ScFv637

The purified pHEN2-ScFv637 from E coli DH5 $\alpha$ was transformed into calcium chloridetreated competent E coli HB2151 for production of soluble ScFv637. The transformant E coli HB2151 were grown from a single colony overnight at $37{ }^{\circ} \mathrm{C}$ in a $5 \mathrm{ml} 2 \mathrm{x}$ TY medium containing $100 \mu \mathrm{g} / \mathrm{ml}$ ampicillin and $1 \%$ glucose, and subsequently diluted in $500 \mathrm{ml} 2 \mathrm{x}$ TY medium with $100 \mu \mathrm{g} / \mathrm{ml}$ ampicillin and $0.1 \%$ glucose. The culture was further incubated at $37^{\circ} \mathrm{C}$ to an $\mathrm{OD}_{600 \mathrm{~nm}}$ of 0.6 . The expression was induced by addition of isopropyl- $\beta$-D-thiogalactopyranoside (IPTG) at final concentration of $1 \mathrm{mM}$. After an additional $3 \mathrm{~h}$ of incubation at $30{ }^{\circ} \mathrm{C}$ with shaking, the bacteria were harvested by centrifugation at $10000 \mathrm{xg}$ for $10 \mathrm{~min}$ at $4{ }^{\circ} \mathrm{C}$.

The periplasmic fraction of ScFv637 was prepared with sodium borate[35]. The bacterial pellet was resuspended in $5 \mathrm{ml}$ ice-cold sodium borate solution $(200 \mathrm{mM}$ sodium borate, $160 \mathrm{mM}$ sodium chloride, $1 \mathrm{mM}$ EDTA, $\mathrm{pH}$ 8.0). After incubation on ice for $20 \mathrm{~min}$, the bacterial suspension was centrifuged at $15000 \mathrm{xg}$ for $10 \mathrm{~min}$ at $4{ }^{\circ} \mathrm{C}$. The supernatant represented the periplasmic fraction. E coli HB2151 which do not bear pHEN2-ScFv637 or bear pHEN2 only were used as control.

\section{Detection of ScFv637}

The production of soluble ScFv637 was detected with nitrocellulose dot blot[36]. A $5 \mu 1$ of periplasmic fraction or culture supernatant of ScFv637 was loaded on nitrocellulose filter $(0.45 \mu \mathrm{m}$, Bio Rad). Non-specific binding sites on the filter were blocked for $1 \mathrm{~h}$ at room temperature in PBS containing 2\% dried skimmed milk, and subsequently incubated with $300 \mathrm{ng} / \mathrm{ml}$ of mouse anti-c-myc mAb ( a kind gift of Dr R. Fischer, Institute of Biology I, RWTH Aachen, Germany) for $1 \mathrm{~h}$ at room temperature with gentle shaking. After washing 3 times with PBS containing 0.05\% Tween 20 and 2 times with PBS alone, the binding of ScFv637 to anti-c-myc mAb was detected by adding rabbit anti- mouse IgG conjugated with HRP (1/2000, Pierce). The HRP activity was visualized with diaminobenzidine tetrahydrochloride (DAB). 
Purification of ScFv637

The purification of ScFv637 was performed with immobilized metal affinity chromatography (IMAC) using nickel-nitrolotriacetic acid (Ni-NTA) agarose (QIAGEN, Westburg bv, Leusden, The Netherlands). Periplasmic fraction of E coli HB2151 made with sodium borate solution was dialysed against lysis buffer $\left(50 \mathrm{mM} \mathrm{NaH}_{2} \mathrm{PO}_{4}, 300 \mathrm{mM}\right.$ $\mathrm{NaCl}, 3 \mathrm{mM}$ imidazole, $\mathrm{pH}$ 8.0), and loaded on Ni-NTA resin column. After washing with wash buffer (50 $\mathrm{mM} \mathrm{NaH}_{2} \mathrm{PO}_{4}, 300 \mathrm{mM} \mathrm{NaCl}, 20 \mathrm{mM}$ imidazole, $\mathrm{pH}$ 8.0), the column was eluted with elution buffer $\left(50 \mathrm{mM} \mathrm{NaH} \mathrm{PO}_{4}, 300 \mathrm{mM} \mathrm{NaCl}, 250 \mathrm{mM}\right.$ imidazole, $\mathrm{pH}$ 8.0). The collected elution fractions were analysed by $12 \%$ SDS-PAGE. Protein bands were detected by Coomassie staining and ScFv637 by Western blotting using mouse anti-c-myc mAb.

\section{Determination of ScFv637 specificity}

The specificity of ScFv637 binding to AChR was determined with precipitation RIA using crude hAChR extract as antigen. Briefly, $200 \mu \mathrm{l}$ of periplasmic fraction of ScFv637 were incubated with $200 \mu \mathrm{l}$ of crude hAChR extract (preincubated with 2 pmol ${ }^{125} \mathrm{I}-\alpha-$ $\mathrm{BT} / \mathrm{pmol} \mathrm{AChR}$ for $4 \mathrm{~h}$ at $4{ }^{\circ} \mathrm{C}$ ) overnight at $4{ }^{\circ} \mathrm{C}$, and further incubated with $100 \mu \mathrm{l}$ mouse anti-c-myc mAb $(10 \mu \mathrm{g} / \mathrm{ml})$ for additional $2 \mathrm{~h}$ at $4{ }^{\circ} \mathrm{C}$. The complex of hAChRScFv637-anti-mouse c-myc mAb was precipitated by addition of goat anti-mouse IgG and bound activity was counted in $\gamma$ counter.

The cross-reactions of ScFv637 to rat AChR (rAChR) or Torpedo AChR (tAChR) were also tested by RIA using $200 \mu 1$ of crude rAChR extracted from rat muscle or 200 $\mu \mathrm{l}$ of purified tAChR $(0.25 \mu \mathrm{g} / \mathrm{ml})$ isolated from electric organ of Torpedo californica (Pacific Biomarine, California, USA).

\section{Immunohistochemical staining of ScFv637}

Binding of ScFv637 to AChR in situ at the neuromuscular junction was verified by immunohistochemical staining on monkey Macaca fascicularis intercostal muscle section 
(a kind gift from Dr M. Jonker, Biomedical Primate Research Center, Rijswijk, The Netherlands). Slides, fixated with cold acetone for $10 \mathrm{~min}$ at $4{ }^{\circ} \mathrm{C}$, were preincubated with PBS containing 2\% BSA, and subsequently incubated with 1/10 diluted periplasmic fraction of bacteria for $1 \mathrm{~h}$ at room temperature. After washing 3 times with PBS with 5 min for each time, slides were incubated with mouse anti-c-myc mAb together with rhodamine-labeled $\alpha-\mathrm{BT}\left(\alpha-\mathrm{BT}^{\mathrm{Rh}}\right.$, Sigma) for $1 \mathrm{~h}$ at room temperature. The binding activity was visualized by addition of goat anti-mouse IgG conjugated with FITC.

\section{Protection of hAChR from binding of anti-MIR antibodies and MG patient sera}

The protective ability to hAChR was measured in a competitive ELISA between ScFv637 and its intact IgG637 and rat anti-MIR mAb35[37], and in a competitive RIA between ScFv637 and MG patient sera. ELISA plates were coated with $50 \mu 1 \mathrm{mAb} 153(15 \mu \mathrm{g} / \mathrm{ml})$, a rat anti-AChR mAb directed against a cytoplasmic epitope[38], for $1 \mathrm{~h}$ at $37{ }^{\circ} \mathrm{C}$, then blocked with PBS containing 3\% BSA and 0.05\% Tween 20. The plates were incubated overnight at $4{ }^{\circ} \mathrm{C}$ with $50 \mu \mathrm{hAChR}(0.3 \mathrm{nmol} / \mathrm{L})$ extracted from TE671 cells, and after washing, further incubated with periplasmic fraction of ScFv637 $(0.0032-50 \mu \mathrm{l})$ overnight at $4{ }^{\circ} \mathrm{C}$. For inhibition of $\mathrm{mAb} 35,50 \mu \mathrm{mAb} 35$ conjugated with $\mathrm{HRP}\left(\mathrm{IC}_{50}=\right.$ $0.9 \mu \mathrm{g} / \mathrm{ml}$, predetermined in ELISA) was added and incubated for $1 \mathrm{~h}$ at $37^{\circ} \mathrm{C}$ without washing, and HRP reaction was developed with tetramethylbenzidine (TMB). For inhibition of $\mathrm{IgG637,} 50 \mu \mathrm{lgG637}\left(\mathrm{IC}_{50}=80 \mathrm{ng} / \mathrm{ml}\right.$, predetermined in ELISA) was added and incubated for $1 \mathrm{~h}$ at $37{ }^{\circ} \mathrm{C}$ without washing. Subsequently $50 \mu$ goat antihuman IgG (Fc specific) coupled with alkaline phosphatase (AP, 1/250, preabsorbed with $1 \%$ normal rat serum at $37^{\circ} \mathrm{C}$ for $1 \mathrm{~h}$ ) was added and incubated for $1 \mathrm{~h}$ at $37{ }^{\circ} \mathrm{C}$, and the color reaction was visualized with p-nitrophenyphosphate (pNPP). In RIA, $50 \mu 1$ hAChR $(0.3 \mathrm{nmol} / \mathrm{L})$ labeled with ${ }^{125} \mathrm{I}-\alpha-\mathrm{BT}$ at $4{ }^{\circ} \mathrm{C}$ for $4 \mathrm{~h}$ was preincubated with $250 \mu \mathrm{l}$ of periplasmic fraction of ScFv637 overnight at $4{ }^{\circ} \mathrm{C}$, subsequently $10 \mu \mathrm{l}$ of MG patient sera (70\% of the maximum binding to hAChR) was added. After an aditional $3 \mathrm{~h}$ incubation at $4{ }^{\circ} \mathrm{C}$, the complex was precipitated by addition of goat anti-human immunoglobulin serum, and the radioactivity was counted. 
The result was expressed as percentage of inhibition of binding of anti-MIR antibodies or MG patient sera.

\section{Results}

Cloning of ScFv637 gene

VH and VL genes of ScFv637 were amplified by PCR from parental Fab637 isolated from thymus-derived phage display library of a MG patient, and subsequently cloned into vector pHEN2. The reconstructed phagemid pHEN2-ScFv637 was transformed into E coli DH5 $\alpha$. After isolation and purification, pHEN2-ScFv637 was digested for the right size of insert of $\mathrm{VH}, \mathrm{VL}$ and $\mathrm{ScFv}$ with the same endonucleases used in cloning, and checked in $1 \%$ agarose gel electrophoresis. The VH, VL and ScFv should be 378 bp, 339 bp and 762 bp in length respectively according to design (Figure 2).

\section{Sequencing of ScFv637 construct}

The complete amino acid sequence of ScFv637 was expressed in Figure 3. The VH and VL sequences of ScFv637 are identical to those of its parental Fab637 at amino acid level although there are two nucleotide differences in primer-encoded sequences of $\mathrm{VH}$ fragment. The original nucleotide sequences of Fab637 were described earlier[27]. 


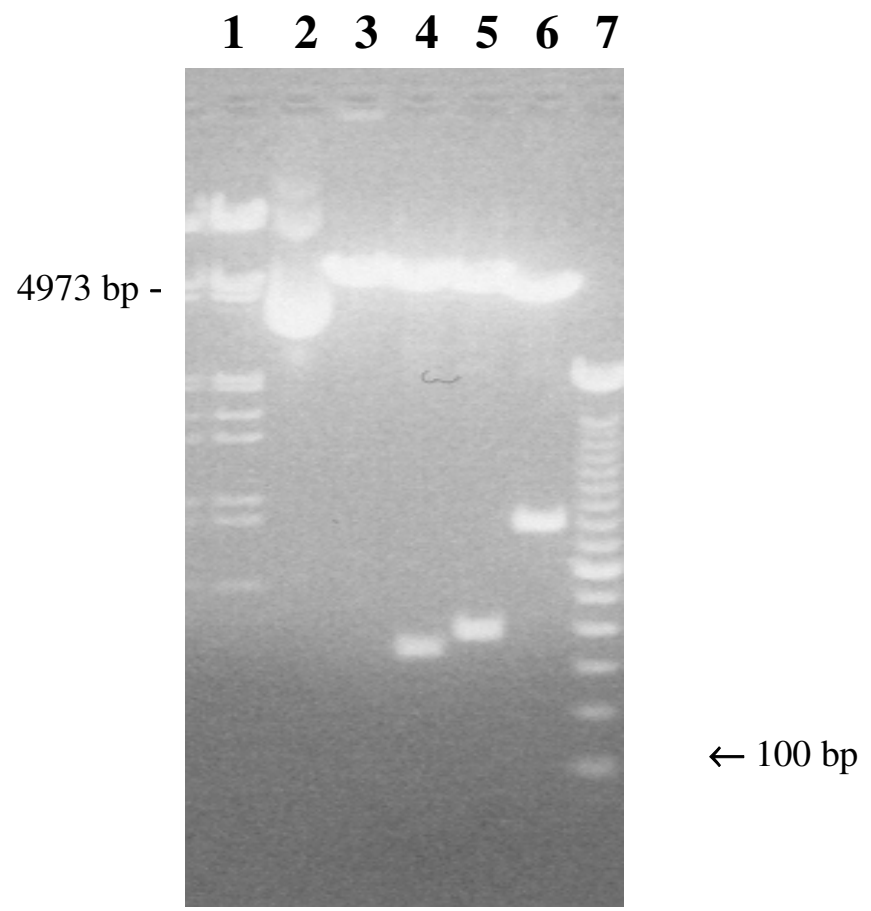

Figure 2 Analysis of ScFv637 construct in 1\% agarose gel electrophoresis. The VH and VL genes of ScFv637 were cloned into phagemid pHEN2 from parental Fab637. After transformation in E coli DH5 $\alpha$, the recombinant pHEN2-ScFv637 were digested with ApaLI/NotI for VL (lane 4), NcoI/XhoI for VH (lane 5), and NcoI/NotI for ScFv637 (lane 6). Lanes 2 and 3 are undigested ScFv637 and ScFv637 digested with XhoI alone respectively. Lanes 1 and 7 are $\lambda$ DNA marker digested with EcoRI/HindIII and 100 bp ladder respectively.

VH

VH upstream primer

\begin{tabular}{llllllll}
\hline 1 & 2 & 3 & 4 & 5 & 6 & 7 & 8 \\
$\mathrm{E}$ & $\mathrm{V}$ & $\mathrm{Q}$ & $\mathrm{L}$ & $\mathrm{L}$ & $\mathrm{E}$ & $\mathrm{S}$ & $\mathrm{G}$
\end{tabular}

FRW1

ScFv637 gag gtg cag ctg ctg gag tct ggg

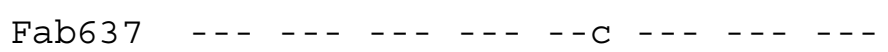

G D L V K P G G S L R L S C A A S G F K S T

$31 \quad 35$

CDR1 D Y Y M S 


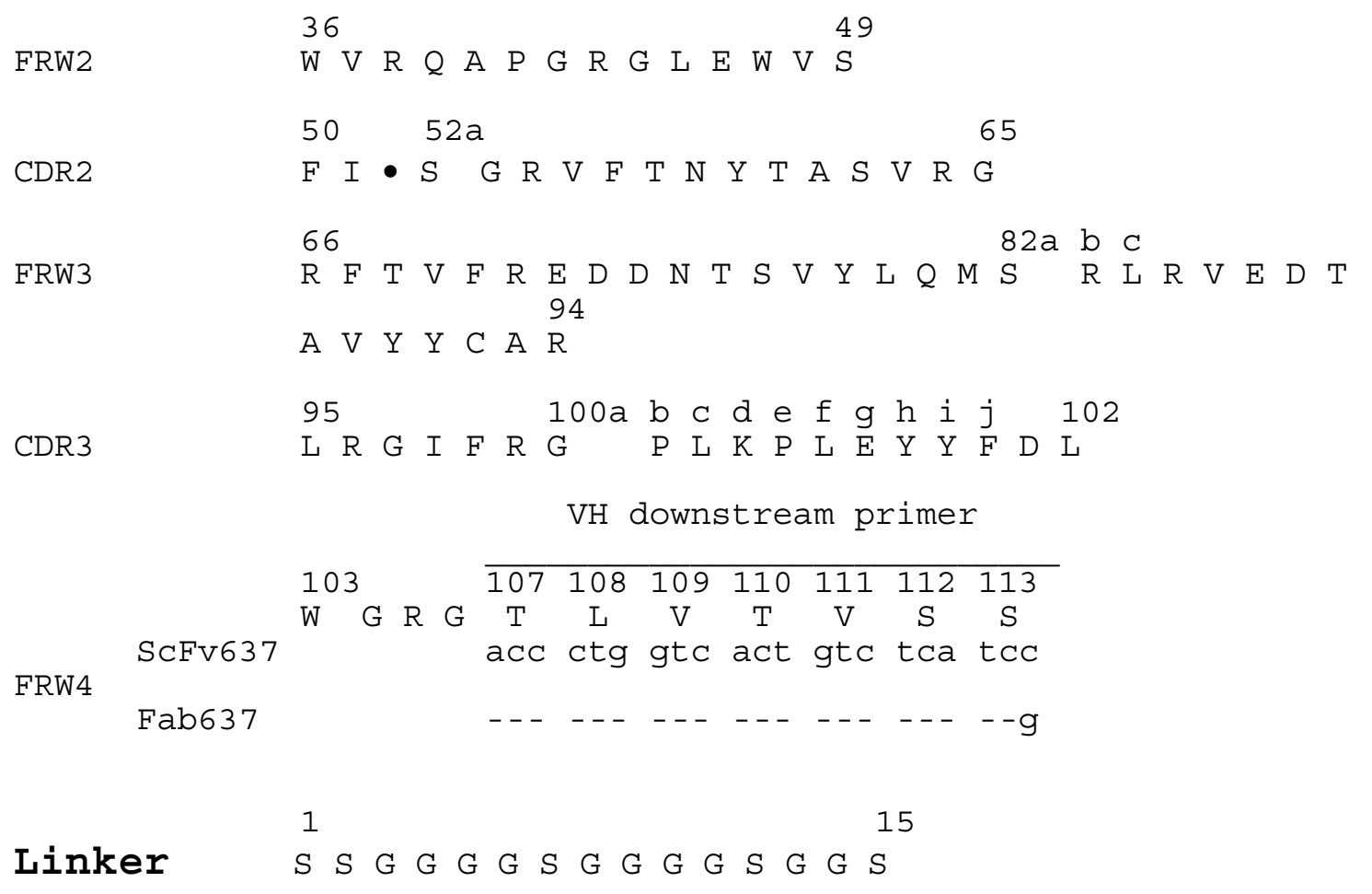

VL

VL upstream primer

\begin{tabular}{lllllll}
\hline 1 & 2 & 3 & 4 & 5 & 6 & 7 \\
$\mathrm{~A}$ & $\mathrm{P}$ & $\mathrm{E}$ & $\mathrm{L}$ & $\mathrm{T}$ & $\mathrm{Q}$ & $\mathrm{P}$
\end{tabular}

FRW1 ScFv637 gca ccc gag ctc act cag cCC

Fab637

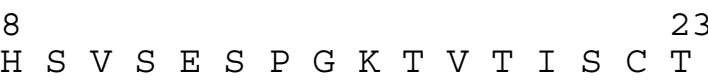

CDR1

$24 \quad 27 a \quad 34$

FRW2

$\begin{array}{llllllllllllll}35 & 49 \\ W & Y & Q & R & P & G & S & S & P & T & V & I & Y\end{array}$

CDR2

$50 \quad 56$

FRW3

$57 \quad 72 \mathrm{a} \mathrm{b}$

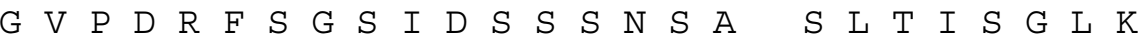
T E D E A D Y Y 


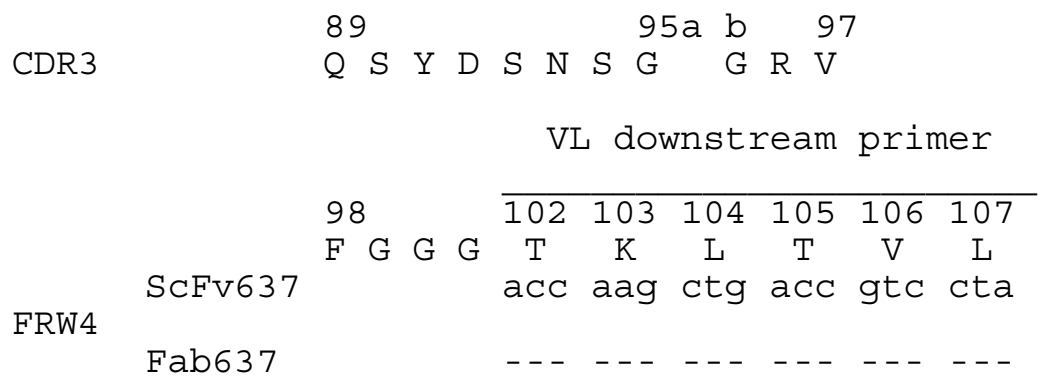

Figure 3 Amino acid sequences of heavy $(\mathrm{H})$ and light $(\mathrm{L})$ chains of ScFv637. The primers used both in PCR amplification of VH and VL genes and for sequencing of ScFv637 are also indicated as nucleotide sequences, and compared with its parental Fab637. The codon "ctc" at amino acid position 5 in VH of Fab637 was changed into "ctg" in ScFv637 to remove XhoI recognition site (ctcgag) without substitution of amino acid. The codon "tcg" $\rightarrow$ "tcc" from Fab637 to ScFv637 at amino acid position 113 of $\mathrm{VH}$ was created in $\mathrm{VH}$ downstream primer to match the XhoI restriction sequence without introduction of an extra amino acid between $\mathrm{VH}$ and linker. The sequence identity of Fab637 with ScFv637 in primers is indicated by dashes. The amino acid position is numbered according to Kabat et al[39]. FRW: framework; CDR: complementarity determining region; $\bullet$ : missing of amino acid.

\section{Expression and purification of soluble ScFv637}

The construct of ScFv637 was transformed into non-suppressor E coli HB2151 for production of soluble ScFv637. The production was detected from both periplasmic fraction and culture supernatant of bacteria by nitrocellulose dot blot assay. The soluble ScFv637 was produced in periplasm but not in culture medium of bacteria after induction of IPTG for $3 \mathrm{~h}$ at $30{ }^{\circ} \mathrm{C}$. However, no production was detectable in either periplasm or culture supernatant of control bacteria or bacteria without induction of IPTG (result not shown).

SDS-PAGE and Western blottiong analysis of fractions from IMAC purification showed that the apparent molecular weight of ScFv637 was approximately $36 \mathrm{kDa}$ although it was calculated to be $30.4 \mathrm{kDa}$ from the amino acid sequence (Figure 4). 


\section{$\begin{array}{llllll}1 & 2 & 3 & 4 & 5 & 6\end{array}$}

A

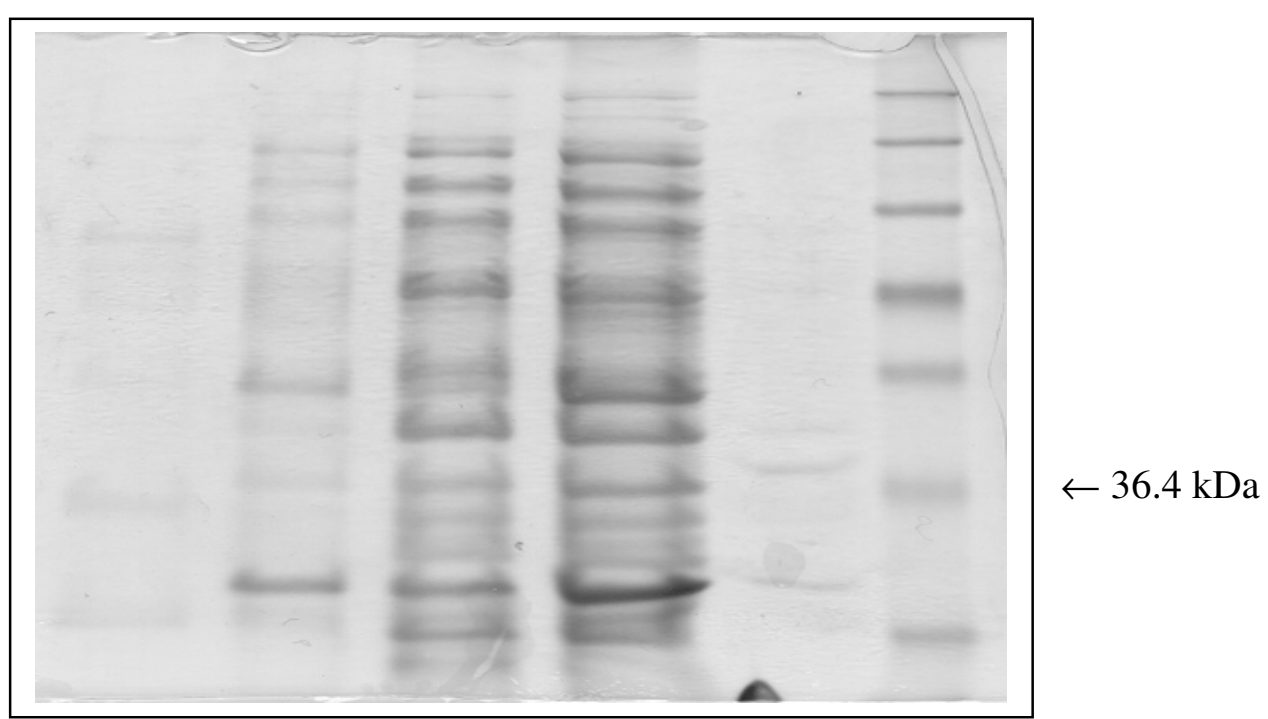

B

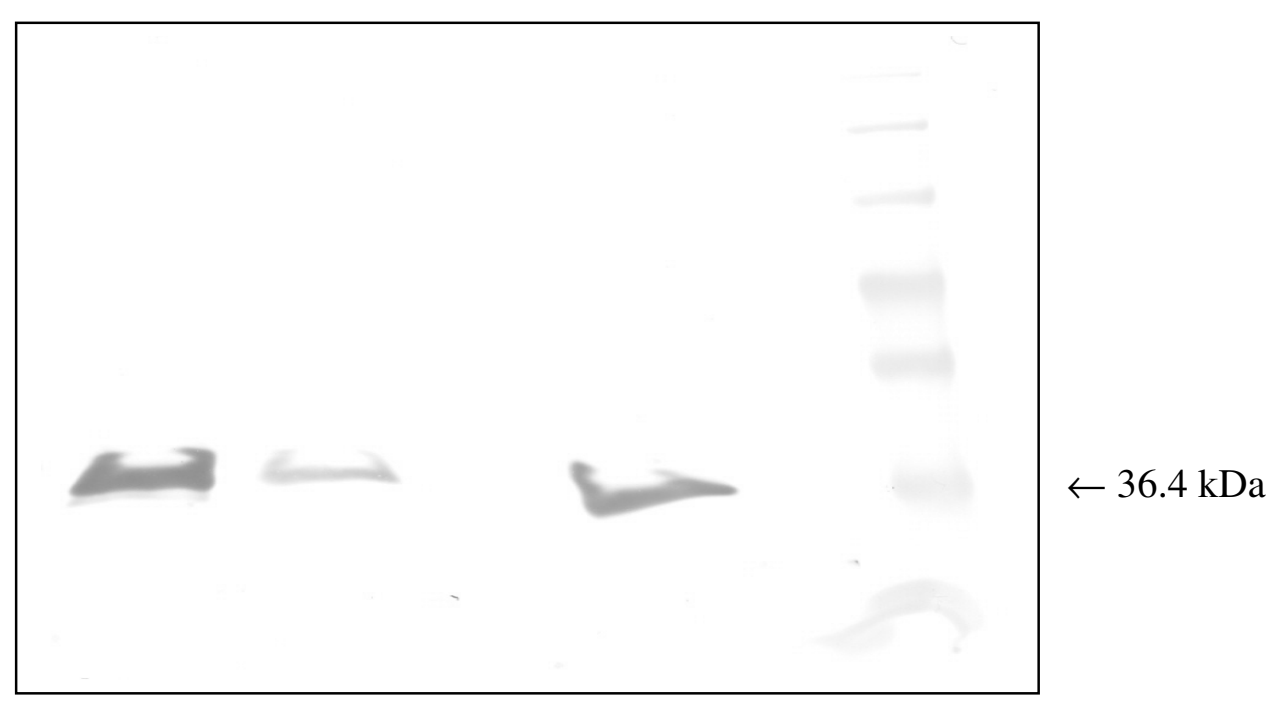

Figure 4 SDS-PAGE and Western blotting analysis of fractions from IMAC purification of ScFv637 carrying c-myc and 6x His tags. Two identical gels were run in parallel. Protein bands were detected by Coomassie staining (A) and the ScFv637 by Western blotting using mouse antic-myc $\mathrm{mAb}$ and followed by rabbit anti-mouse IgG conjugated with HRP and substrate DAB (B). Lanes: 1, eluate with $250 \mathrm{mM}$ imidazole; 2 , washing fraction with $20 \mathrm{mM}$ imidazole; 3, flowthrough; 4, unpurified periplasmic fraction; 5, periplasmic fraction from E coli HB2151 as negative control; 6 , molecular standards. 
Antigen binding activity of ScFv637

The binding activity of ScFv637 to hAChR extracted from TE671 cells was tested in a precipitation RIA. ScFv637 produced in periplasm of different colonies of bacteria determined in nitrocellulose dot blot were able to bind hAChR but not rAChR or tAChR. Whereas, no binding activity was found in bacterial culture medium and in control bacteria (Figure 5).

ScFv637 could also cross-react with monkey AChR at neuromuscular junction of monkey intercostal muscle section. ScFv637 bound to endplate regions (Figure 6, A and C) which were colocalized in the same slides with $\alpha-\mathrm{BT}^{\mathrm{Rh}}$ (Figure $6, \mathrm{~B}$ and D).

Protective capacity of ScFv637 to hAChR

The inhibition of ScFv637 to anti-MIR antibodies or MG patient sera for binding to hAChR was determined in a competitive ELISA or RIA. ScFv637 expressed in periplasmic fraction of $\mathrm{E}$ coli HB2151 inhibited the binding of anti-MIR mAb35 to hAChR up to $73.0 \%$, whereas it inhibited the binding of its intact IgG637 only up to $32.9 \%$ (Figure 7A), probably due to its low afinity and the very high affinity of IgG637 to hAChR (unpublished data). ScFv637 could also inhibit the binding of MG patient sera to hAChR from $27.8 \%$ to $45.5 \%$ (Figure $7 \mathrm{~B}$ ), clearly indicating its protective capacity towards a broad range of polyclonal anti-AChR antibodies. 


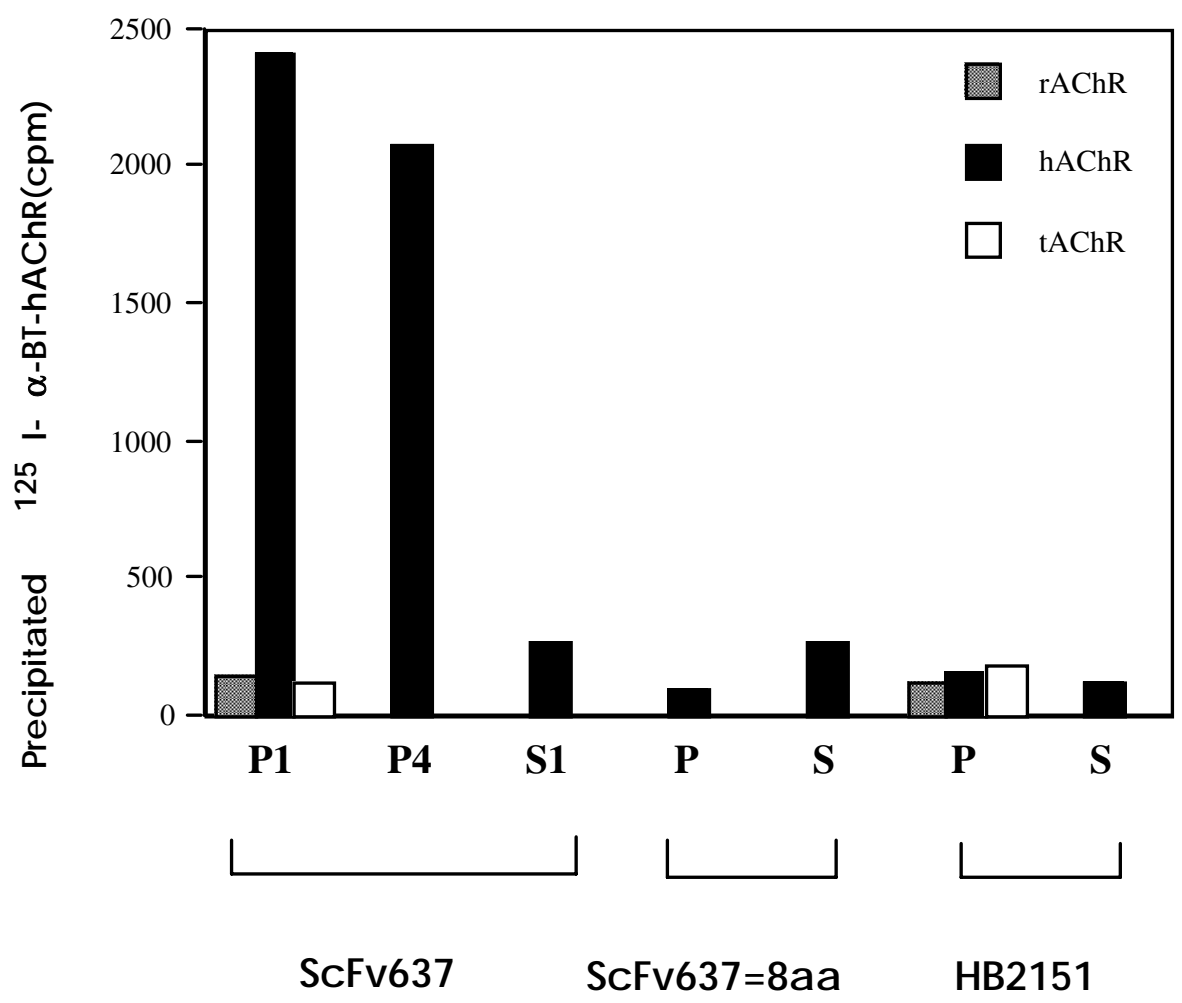

Figure 5 Binding activities of ScFv637 to AChR. ${ }^{125} \mathrm{I}-\alpha-\mathrm{BT}-\mathrm{AChR}-\mathrm{ScFv} 637$ was precipitated by addition of mouse anti-c-myc mAb and goat anti-mouse IgG in standard precipitation RIA. hAChR: human AChR isolated from TE671 cells; rAChR: rat AChR isolated from rat muscle; tAChR: Torpedo AChR isolated from electric organ of Torpedo californica; P: periplasmic fraction; S: culture supernatant; ScFv637=8aa: ScFv637 without the first 8 amino acids of VH and VL; HB2151: control bacterium E coli HB2151; Numbers represent different bacterial colonies. 
A

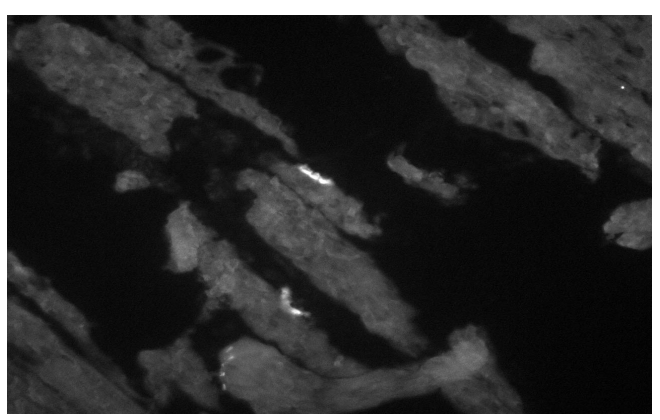

C

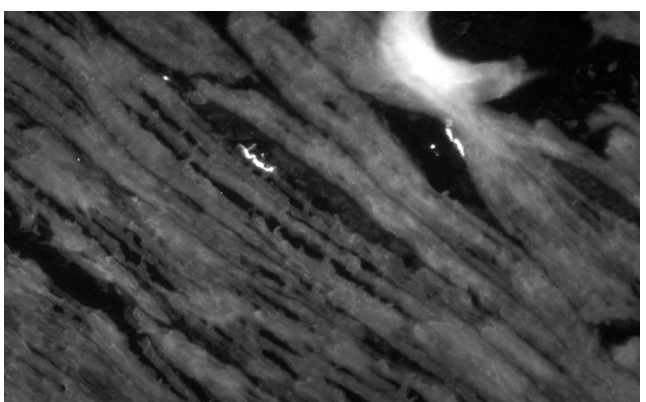

$\mathbf{E}$

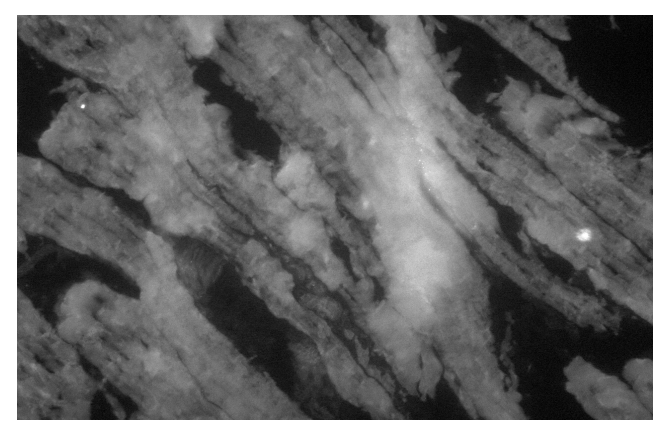

B

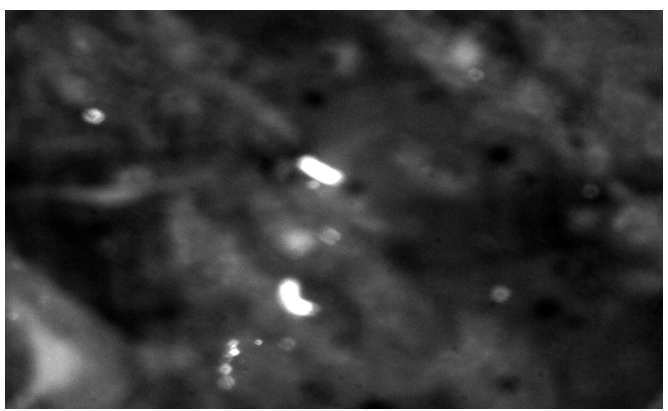

D

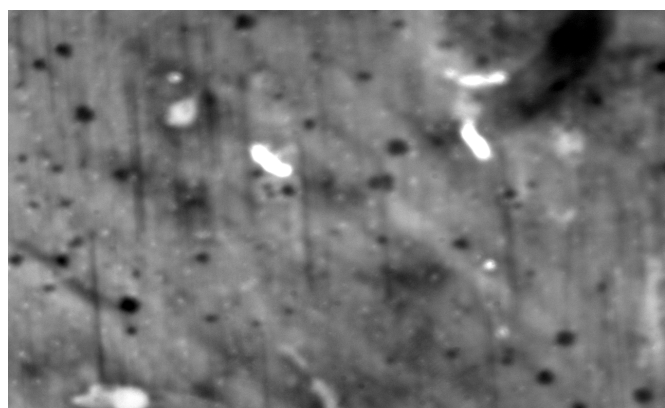

$\mathbf{F}$

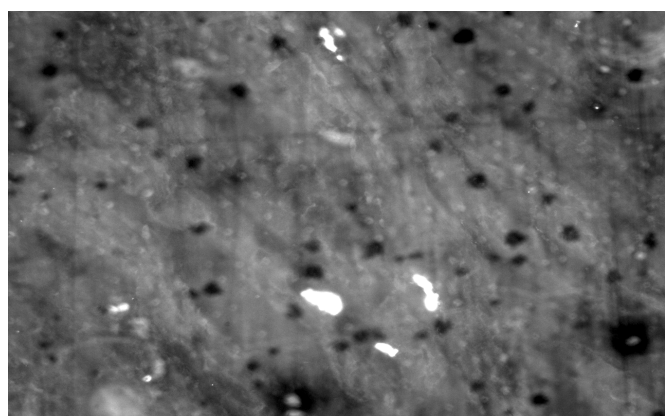

Figure 6 Binding of ScFv637 to AChR in situ at neuromuscular junction of monkey intercostal muscle section. The binding of ScFv637 to AChR at endplate was demonstrated by immunohistochemical staining. Mouse anti-c-myc mAb was used as second antibody and goat anti-mouse IgG conjugated with FITC as for visualization. Rhodamine-labeled $\alpha-\mathrm{BT}\left(\alpha-\mathrm{BT}^{\mathrm{Rh}}\right)$ was used to colocalize the same endplates. A and C: ScFv637 colonies 1 and 4 bound to AChR at endplates; B and D: Colocalization of AChR in the same endplates as in A and C respectively; E: ScFv637 without the first 8 amino acids of VH and VL (ScFv637=8aa) failed to bind to AChR at endplates; F: Colocalization of AChR in the same endplates as in E. Magnification: $x 200$. 


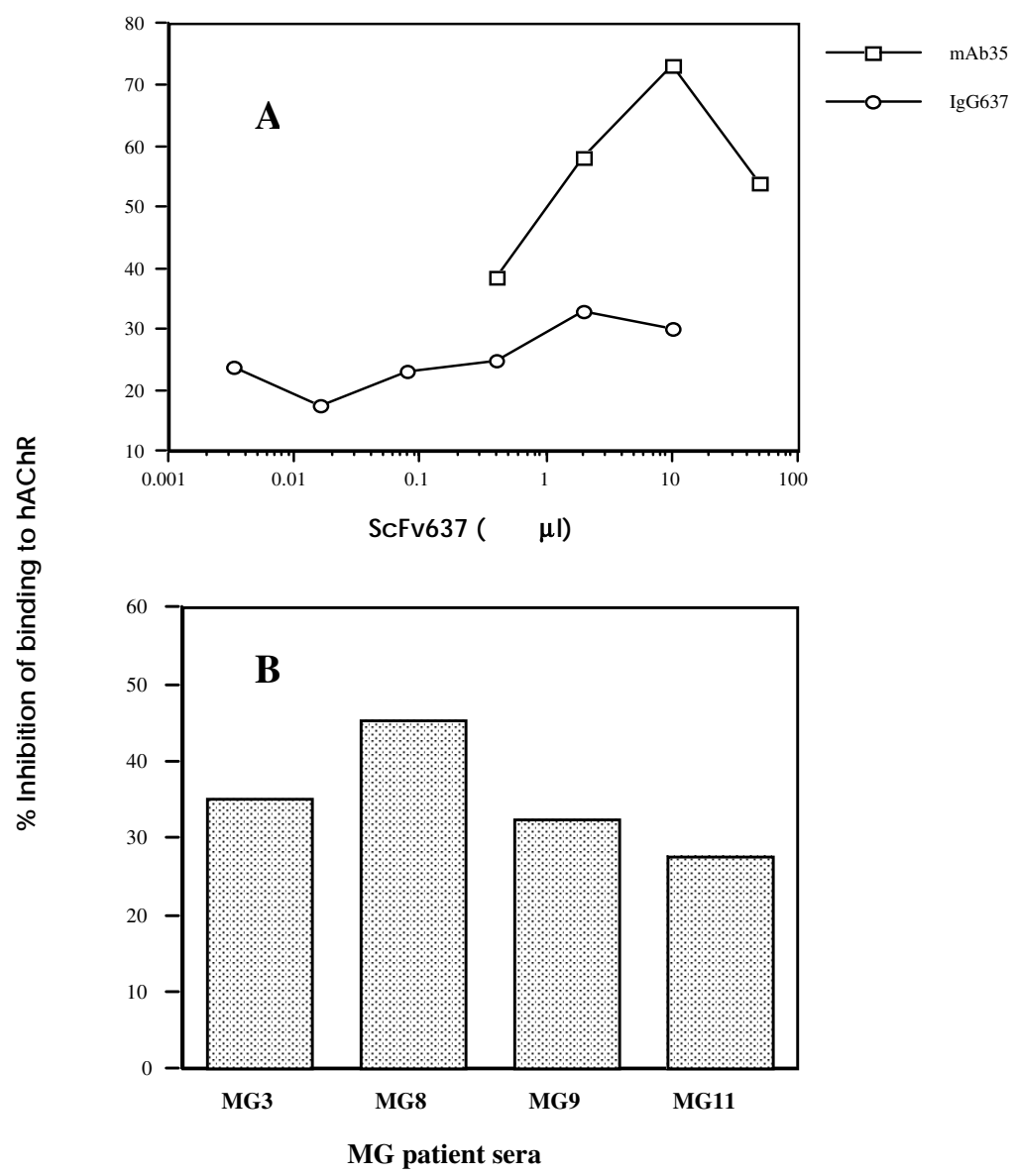

Figure 7 Inhibition of binding of anti-MIR antibodies and MG patient sera to hAChR by ScFv637. A: ScFv637 was tested for the ability to inhibit the binding of its intact IgG637 and rat anti-MIR mAb35 to hAChR in an ELISA. HAChR was captured by fixed mAb153 and incubated with various amounts of periplasmic fraction of ScFv637. The competition was determined at $50 \%$ of the maximum binding of IgG637 or mAb35 to hAChR. B: Capacity of ScFv637 to protect hAChR from binding of MG patient sera was tested in a RIA. HAChR labeled with ${ }^{125} \mathrm{I}-\alpha-\mathrm{BT}$ was preincubated with $250 \mu \mathrm{l}$ of periplasmic fraction of ScFv637, then incubated with MG patient serum (70\% of the maximum binding to $\mathrm{hAChR}$ ) and precipitated with goat anti-human immunoglobulin serum. The result was expressed as percentage of inhibition of binding of antiMIR antibodies or MG patient sera to hAChR. 


\section{Discussion}

Pathogenic anti-AChR antibodies are mainly those that are directed against MIR due to the bivalent nature of whole molecule of antibody and make up most part of the total antiAChR antibodies in both MG and EAMG. However, Fab or ScFv fragments can not themselves cross-link AChR to cause antigenic modulation since they are monovalent and can not activate the complement cascade to cause focal lysis of postsynaptic membrane since they lack Fc fragment. Fab or ScFv derived from anti-MIR antibodies could block the binding of MG patient sera or their parental anti-MIR antibodies to $\mathrm{AChR}[27,33]$, and protect the AChR from antigenic modulation induced by MG patient sera or anti-MIR mAbs in cultured TE671 cells[27, 29, 31, 32].

Fab637 is a MG thymus-derived anti-MIR fragment[27]. It prevents MG serum from binding to $\mathrm{hAChR}$ and protects $\mathrm{AChR}$ from loss induced by $\mathrm{MG}$ serum. Since Fab637 can bind monkey AChR in situ on monkey intercostal muscle section, it is ideal to test its in vivo protective ability in monkey before clinical application in MG patient (a large-scale production of Fab637 by transfecting it into chinese hamster ovary cells for mammalian expression is in progress). We have constructed a ScFv637 derived from its parental Fab637. The aim of this study is to try an alternative possibility using antibody fragment for the specific immunosuppressive therapy of MG. Furthermore, since ScFv is smaller than Fab, and $\mathrm{VH}$ and $\mathrm{VL}$ genes of $\mathrm{ScFv}$ are located in the same cistron, this property makes it easier for manipulation of genetic improvement in its affinity and stability.

ScFv637 was constructed from VH and VL genes of Fab637 by PCR amplification on vector pHEN2 which contains a GS (Gly and Ser) rich linker, and a cmyc tag and a 6x His tag for specific detection and efficient purification. The VH upstream primer was designed according to the first 8 codons of Fab637 VH fragment. However, the first 6 codons used in Fab637 was artificially designed in vector pComb3H, and codons 5 and 6 (ctc gag) was used as XhoI restriction site for original cloning of $\mathrm{VH}$. Since vector pHEN2 contains the same XhoI restriction site for cloning and we prefer the VH-linker-VL orientation construct of ScFv, therefore, "ctc" in codon 5 was changed into "ctg" to remove the XhoI restriction site without substitution of amino acid. Similarly, 
codon "tcg" $\rightarrow$ "tcc" from Fab637 to ScFv at amino acid position 113 of VH was created in $\mathrm{VH}$ downstream primer to match the XhoI site without introduction of an extra amino acid between VH and linker. For the VL cloning, codon "gca" (encoding Ala) in ApaLI restriction sequence was designed in VL upstream primer as first codon of VL of ScFv637 and "ccc" (encoding Pro) as second codon to match both ApaLI restriction site and annealing to template in $\mathrm{pComb} 3 \mathrm{H}$.

The reconstructed pHEN2-ScFv637 was transformed into non-suppressor E coli HB2151 for soluble ScFv production which was detected in nitrocellulose dot blot using mouse anti-c-myc mAb. The specificity of ScFv637 binding to hAChR was determined in RIA in which ScFv637 first bound to AChR and then c-myc tag in the complex of ScFv637-AChR was recognized by mouse anti-c-myc mAb. However, interestingly, when SPRIA, in which c-myc tag of ScFv637 was captured first by fixed mouse anti-cmyc mAb and then ScFv637 in the complex of mAb-ScFv637 bound to AChR, was utilized to determine the specificity of ScFv637 binding to hAChR, no binding activity could be found (data not shown). In contrast, its parental Fab637 could bind AChR in SPRIA suggesting that the binding of anti-c-myc mAb to c-myc tag (C-terminus) of ScFv637 may interfere with the binding of ScFv637 to AChR. A similar result was described in a previous study of Goel et al[40] who found that the C-terminal position of His tag partially covered the antigen binding site and affected the binding properties of $\mathrm{ScFv}$ construct in SPRIA. Although several studies showed that the affinity tags of different types had no significant effects on the activity of native proteins[41-48], it will be nice to determine the effects of the N-terminal c-myc tag of ScFv637 on its specificity since the effects of affinity tags on specificity of $\mathrm{ScFv}$ depend on the primary sequences and conformation of the $\mathrm{ScFv}$. It was also reported that $\mathrm{ScFv}$ exhibited higher crossreactivity with analogs of the antigen originally used for production of its parental mAb[49]. Nevertheless, ScFv637, just like its parental Fab637, could specifically bind to $\mathrm{AChR}$ in situ at monkey neuromuscular junction but did not cross-react with rAChR or tAChR.

We also construct a $\mathrm{ScFv}$ from Fab637 without the first 8 amino acids in framework 1 of both VH and VL (ScFv637=8aa). ScFv637=8aa was efficiently produced in both periplasmic fraction and culture supernatant of bacteria as detected by nitrocellulose dot blot, however no specificity of ScFv637=8aa binding to hAChR was 
observed in SPRIA or RIA (Figure 5). Furthermore ScFv637=8aa was not able to bind AChR at endplate of monkey muscle section either (Figure 6, E and F). Li et al[50] also found that the sequence changes of the $\mathrm{V}$ region $\mathrm{N}$-terminus introduced by PCR may seriously affect antigen binding but not the expression of antibody. Several other groups noted the same phenomena[51-54]. Since the N-terminus of both V domains can be contiguous with the complementarity determining region (CDR) surface [55] they would influence the structure of the combining site and the antigen binding characteristics of antibodies.

Competition experiment showed that ScFv637 was able to protect hAChR from the binding of anti-MIR antibodies and MG patient sera, which makes it an alternative candidate for specific immunosuppressive therapy compared with its parental Fab637. Presently we are trying to make a conjugate by linking it with human serum albumin (HSA) or polyethylenoglycol (PEG) to increase its half-life.

\section{Acknowledgements}

We would like to thank Drs G. Winter, R. Fischer, M. Jonker and S. Tzartos for kindly supplying pHEN2, anti-c-myc mAb, monkey muscle and mAb35, mAb153 respectively. We are also grateful to Dr B. Machiels for excellent laboratory assistance and helpful discussion. This work was supported by a grant from Het Prinses Beatrix Fonds. 


\section{References}

1 Lindstrom J, Shelton D, Fujii Y. Myasthenia gravis. Adv Immunol, 1988, 42: 233-284

2 Graus Y, de Baets M. Myasthenia gravis: an autoimmune response against the acetylcholine receptor. Immunol Res, 1993, 12: 78-100

3 Drachman B. Myasthenia gravis. N Eng J Med, 1994, 330: 1797-1810

4 Lindstrom J, Lennon V, Seybold M, Whittingham S. Experimental autoimmune myasthenia gravis and myasthenia gravis: Biochemical and immunochemical aspects. Ann NY Acad Sci, 1976, 274: 254-274

5 Toyka KV, Drachman DB, Pestronk A, Kao I. Myasthenia gravis: Passive transfer from man to mouse. Science, 1975, 190: 397-399

6 Tzartos SJ, Hochschwender S, Vasquez P, Lindstrom J. Passive transfer of experimental autoimmune myasthenia gravis by monoclonal antibodies to the main immunogenic region of the acetylcholine receptor. J Neuroimmunol, 1987, 15: 185194

7 Conti-Tronconi B, Mclane K, Raftery M, Grando S, Protti M. The nicotinic acetylcholine receptor: structure and autoimmune pathology. Crit Rev Biochem Mol Biol, 1994, 29: 69-123

8 Lindstrom J, Merlie J, Yogeeswaran G. Biochemical properties of acetylcholine receptor subunits from Torpedo californica. Biochemistry, 1979, 18: 4465-4470

9 Raftery MA, Hunskappiler MW, Stradler CD, Hood LE. acetylcholine receptor: complex of homologous subunits. Science, 1980, 208: 1454-1457

10 Kubalek E, Ralston S, Lindstrom J, Unwin N. Localization of subunits within the acetylcholine receptor by electron image analysis of tubular crystals from Torpedo marmorata. J Cell Biol, 1987, 105: 9-18

11 Barkas T, Mauron A, Roth B, Alliod C, Tzartos S, Ballivet M. Mapping of the main immunogenic region and toxin binding site of the nicotinic acetylcholine receptor. Science, 1987, 235: 77-80

12 Barkas T, Gabriel J-M, Mauron A, Hughes G, Roth B, Alliod C, Tzartos S, Ballivet M. Monoclonal antibodies to the main immunogenic region of the nicotinic 
acetylcholine receptor binds to residues $61-76$ of the $\alpha$-subunit. J Biol Chem, 1988, 263: $5916-5920$

13 Tzartos SJ, Kokla A, Walgrave S, Conti-Tronconi B. Localization of the main immunogenic region of the human muscle acetylcholine receptor to residues 67-76 of the $\alpha$-subunit. Proc Natl Acad Sci USA, 1988, 85: 2899-2903

14 Tzartos SJ, Lindstrom JM. Monoclonal antibodies used to probe acetylcholine receptor structure: localization of the main immunogenic region and detection of similarities between subunits. Proc Natl Acad Sci USA, 1980, 77: 755-759

15 Tzartos SJ, Seybold ME, Lindstrom JM. Specificities of antibodies to acetylcholine receptors in sera from myasthenia gravis patients measured by monoclonal antibodies. Proc Natl Acad Sci USA, 1982, 79: 188-192

16 Tzartos S, Barkas T, Cung M, Mamalaki A, Marraud M, Papanastasiou D, Sakarellos C, Sakarellos-Daitsiotis M, Tsantili P, Tsikaris V. Anatomy of the antigenic structure of a large membrane autoantigen, the muscle-type nicotinic acetylcholine receptor. Immunol Rev, 1998, 163: 89-120

17 Lennon V, Lambert E. Myasthenia gravis induced by monoclonal antibodies to acetylcholine receptor. Nature, 1980, 285: 238-240

18 Graus Y, Meng F, Vincent A, van Breda Vriesman P, de Baets M. Sequence analysis of anti-AChR antibodies in experimental autoimmune myasthenia gravis. J Immunol, 1995, 154: 6382-6396

19 Tzartos SJ, Starzinski-Powitz A. Decrease in acetylcholine-receptor content of human myotube cultures mediated by monoclonal antibodies to $\alpha, \beta$ and $\gamma$ subunits. FEBS Lett, 1986, 196: 91-95

20 Souroujon M, Pachner A, Fuchs S. The treatment of passively transferred experimental myasthenia with anti-idiotypic antibodies. Neurology, 1986, 36: 622625

21 Wang Z-Y, Qiao J, Link H. Suppression of experimental autoimmune myasthenia gravis by oral administration of acetylcholine receptor. J Neuroimmunol, 1993, 44: 209-214 
22 Wang Z-Y, Qiao J, Melms A, Link H. T cell reactivity to acetylcholine receptor in rats orally tolerized against experimental autoimmune myasthenia gravis. Cell Immunol, 1993, 152: 394-404

23 Wang Z-Y, Huang J, Olsson T, He B, Link H. B cell responses to acetylcholine receptor in rats orally tolerized against experimental autoimmune myasthenia gravis. J Neurol Sci, 1995, 128: 167-174

24 Karachunski P, Ostlie N, Okita D, Conti-Fine B. Prevention of experimental myasthenia gravis by nasal administration of synthetic acetylcholine receptor $\mathrm{T}$ epitope sequences. J Clin Invest, 1997, 100: 3027-3035

25 Barchan D, Sourojon M, Im S-H, Antozzi C, Fuchs S. Antigen specific modulation of experimental myasthenia gravis: nasal tolerization with recombinant fragments of the human acetylcholine receptor $\alpha$ subunit. Proc Natl Acad Sci USA, 1999, 96: 80868091

26 Shi FD, Li H, Wang H, Bai X, Van de Meide P, Link H, Ljunggren HG. Mechanisms of nasal tolerance induction in experimental autoimmune myasthenia gravis: identification of regulatory cells. J Immunol, 1999, 162: 5757-5763

27 Graus Y, de Baets M, Parren P, Berrih-Aknin S, Wokke J, van Breda Vriesman P, Burton D. Human anti-nicotinic acetylcholine receptor recombinant Fab fragments isolated from thymus-derived phage display libraries from myasthenia gravis patients reflect predominant specificities in serum and block the action of pathogenic serum antibodies. J Immunol, 1997, 158: 1919-1929

28 Farrar J, Portolano S, Willcox N, Vincent A, Jacobson L, Newsom-Davis J, Rapoport B, McLachlan SM. Diverse Fab specific for acetylcholine receptor epitopes from a myasthenia gravis thymus combinatoral library. Int Immunol, 1997, 9: 1311-1318

29 Sophianos D, Tzartos S. Fab fragments of monoclonal antibodies protect the human acetylcholine receptor against degradation caused by myasthenic sera. J Autoimmun, 1989, 2: 779-789

30 Papanastasiou D, Poulas K, Kokla A, Tzartos SJ. Prevention of passively transferred experimental autoimmune myasthenia gravis by Fab fragments of monoclonal antibodies directed against the main immunogenic region of the acetylcholine receptor. J Neuroimmunol, 2000, 104: 124-132 
31 Papanastasiou D, Mamalaki A, Eliopoulos E, Poulas K, Liolitsas C, Tzartos S. Construction and characterization of a humanized single chain Fv antibody fragment against the main immunogenic region of the acetylcholine receptor. $J$ Neuroimmunol, 1999, 94: 182-185

32 Mamalaki A, Trakas N, Tzartos SJ. Bacterial expression of single-chain Fv fragment which efficiently protects the acetylcholine receptor against antigenic modulation caused by myasthenic antibodies. Eur J Immunol, 1993, 23: 1839-1845

33 Tsantili P, Tzartos SJ, Mamalaki A. High affinity single-chain antibody fragments protecting the human nicotinic acetylcholine receptor. J Neuroimmunol, 1999, 94: 1527

34 Luther M, Schoepfer R, Whiting P, Casey B, Blatt Y, Montal M, Montal M, Lindstrom J. A muscle acetylcholine receptor is expressed in the human cerebellar medulloblastoma cell line TE671. J Neurosci, 1989, 9: 1082-1096

35 De Wildt R, Finnern R, Ouwehand W, Griffiths A, van Venrooij W, Hoet R. Characterization of human variable domain antibody fragments against the U1 RNAassociated A protein, selected from a synthetic and a patient-derived combinatoral $\mathrm{V}$ gene library. Eur J Immunol, 1996, 26: 629-639

36 Hoet R, Koornneef I, de Rooij D,van de Putte L, van Venrooij W. Changes in anti-U1 RNA antibody levels correlate with disease activity in patients with systemic lupus erythematosus overlap syndrome. Arthritis Rheum, 1992, 35: 1202-1210

37 Kordossi AA, Tzartos SJ. Monoclonal antibodies against the main immunogenic region of the acetylcholine receptor: mapping on the intact molecule. $J$ Neuroimmunol, 1989, 23: 35-40

38 Tzartos S, Remoundos M. Precise epitope mapping of monoclonal antibodies to the cytoplasmic site of the acetylcholine $\alpha$-subunit. Dissecting a potentially myasthenogenic epitope. Eur J Biochem, 1992, 207: 915-922

39 Kabat E, Wu T, Perry H, Gottesman K, Foeller C. Sequences of proteins of immunological interest. $5^{\text {th }}$ ed, No 91-3242. National Institute of Health, Bethesda, MD. 1991

40 Goel A, Colcher D, Koo JS, Booth B, Pavlinkova G, Batra S. Relative position of the hexahistidine tag effects binding properties of a tumor-associated single-chain $\mathrm{Fv}$ construct. Biochim Biophys Acta, 2000, 1519: 13-20 
$41 \mathrm{Xu}$ B, Kriangkum J, Nagata LP, Fulton RE, Suresh MR. A single chain Fv specific against Western equine encephalitis virus. Hybridoma, 1999, 18: 315-323

42 Alcocer MJ, Doyen C, Lee HA, Morgan MR, Properties of polyclonal, monoclonal, and recombinant antibodies recognizing the organophosphorus pesticide chlorpyrifosethyl. J Agric Food Chem, 2000, 48: 4053-4059

43 Hasshimoto Y, Ikenaga T, Tanigawa K, Ueda T, Ezakl I, Imoto T. Expression and characterization of human rheumatoid factor single-chain Fv. Biol Pharm Bull, 2000, 23: $941-945$

44 Kuderova A, Tanha J, Lee JS. Characterization of four nucleic acid-binding singlechain $\mathrm{Fv}$ fragments by direct and competitive solid-phase radioimmunoassays. J Biol Chem, 1994, 269: 32957-32962

45 Casay JL, Keep PA, Chester KA, Robson L, Hawkins RE, Begent RH. Purification of bacterially expressed single chain Fv antibodies for clinical applications using metal chelate chromatography. J Immunol Methods, 1995, 13: 105-116

46 Long MC, Jager S, Mah DC, Jebailey L, Mah MA, Masri SA, Nagata LP. Construction and characterization of a novel recombinant single-chain variable fragment antibody against Western equine encephalitis virus. Hybridoma, 2000, 19: $1-13$

47 Brown JC, Brown BA 2 nd, Li Y, Hardin CC. Construction and characterization of a quadruplex DNA selective single-chain autoantibody from a viable motheaten mouse hybridoma with homology to telomeric DNA binding proteins. Biochemistry, 1998, 37: $16338-16348$

48 Berdichevsky Y, Ben-Zeev, E, Lamed R, Benhar I. Phage display of a cellulose binding domain from clostridium thermocellum and its application as a tool for antibody engineering. J Immunol Methods, 1999, 228: 151-162

49 Yuan Q, Clarke J, Zhou H-R, Linz J, Pestka J, Hart L. Molecular cloning, expression, and characterization of a functional single-chain $\mathrm{Fv}$ antibody to the mycotoxin zearalenone. Appl Environ Microbiol, 1997, 63: 263-269

$50 \mathrm{Li}$ J, Wang Y, Wang Z, Dong Z. Influnces of amino acid sequences in FR1 region on binding activity of the $\mathrm{scFv}$ and Fab of an antibody to human gastric cancer cells. Immunol Lett, 2000, 71: 157-165 
51 Benhar I, Pastan I. Identification of residues that stabilize the single-chain Fv of monoclonal antibodies B3. J Biol Chem, 1995, 270: 23373-23380

52 Ohtomo T, Tsuchiya M, Sato K, Simizu K, Moriuchi S, Miyao Y, Akimoto T, Akamatsu K, Hayakawa T, Ohsugi Y. Humanization of mouse ONS-M21 antibody with the aid of hybrid variable regions. Mol Immunol, 1995, 32: 407-416

53 Li Y, Spellerberg MB, Stevenson FK, Capra JD, Potter KN. The I binding specificity of human VH 4-34 ( $\mathrm{VH}$ 4-21) encoded antibodies is determined by both $\mathrm{VH}$ framework region 1 and complementarity determining region 3. J Mol Biol, 1996, 256: $577-589$

54 De Haard HJ, Kazemier B, van der Bent A, Absolute conservation of residue 6 of immunoglobulion heavy chain variable regions of class IIA is required for correct folding. Protein Eng, 1998, 11: 1267-1276

55 Padlan EA. A possible procedure for reducing the immunogenicity of antibody variable domains while preserving their ligand-binding properties. Mol Immunol, 1991, 28: 489-498 


\title{
Chapter 5
}

\section{Experimental autoimmune myasthenia gravis in mice expressing human immunoglobulin loci (HuMAb-Mice)}

\begin{abstract}
Antibodies (Abs) specifically directed against the autoantigen, the muscle acetylcholine receptor $(\mathrm{AChR})$, mediate the pathogenesis of myasthenia gravis (MG). The animal model experimental autoimmune MG (EAMG) can be induced by passive transfer or active generation of anti-AChR Abs by immunization. We report a new EAMG mouse model that generates human anti-AChR Abs. Mice transgenic for human $\mu, \gamma 1$, and $\kappa$ germ line genes (HuMAb-Mice) were immunized with Torpedo AChR (tAChR). Serum titers of anti-tAChR Abs were in the nanomolar range, and anti-rodent AChR Abs were in picomolar range. Human Ab-mouse AChR complexes were found at the neuromuscular junction, while AChR loss was up to $65 \%$. Some HuMAb-Mice had signs of muscle weakness, clearly indicating their susceptibility to EAMG. Spleen and lymph nodes were used for producing hybridomas. From the anti-tAChR monoclonal Abproducing hybridomas $2 \%$ had cross-reactivity with rodent AChR. These experiments show that the HuMAb-Mouse represents a suitable model to study the effects of human anti-AChR Abs in vivo.
\end{abstract}




\section{Introduction}

Autoantibodies in the organ-specific autoimmune disease myasthenia gravis (MG) are directed mainly to the acetylcholine receptor (AChR)[1]. Anti-AChR antibodies (Abs) cause a disturbed neuromuscular transmission, either by decrease of AChR concentration or, to a lesser extent, functional inhibition of the ion channel[2, 3]. Two mechanisms that lead to this receptor loss are anti-AChR Ab-activated complement reaction, resulting in focal lysis of the membrane[4, 5], and cross-linking of receptors by Abs that are capable of binding to two AChRs simultaneously, leading to an increased rate of internalization of the receptor (antigenic modulation)[6, 7].

Experimental autoimmune MG (EAMG) is the animal model that resembles MG closely. Immunization of animals with Torpedo $\mathrm{AChR}(\mathrm{tAChR})$, isolated from the ray Torpedo californica, gives rise to anti-tAChR Abs, of which a small percentage crossreacts with autologous AChR and causes EAMG[1, 8]. Passive transfer of MG patient's immunoglobulins (Igs) in mice also induces EAMG, indicating the importance of these human Igs in the pathogenesis of MG[9]. In another study that used patient material, MG thymus tissue was transplanted into severe combined immunodeficiency (SCID) mice, resulting in the production of human anti-AChR Ab titers, but although human Abs were found at the muscle end-plates, EAMG was not induced[10]. Mice have strain-dependent susceptibilities to EAMG, although anti-AChR Ab serum titers and fine specificities are comparable[11, 12]. Mice transgenic for different HLA genes have different susceptibilities to EAMG, implying an important role of these human genes in the pathogenesis of MG[13]. The use of human genes and molecules in EAMG clearly matches the model more closely to MG.

In this study, we demonstrate a new EAMG mouse model. In 1994, Lonberg et al[14] established a mouse strain that was transgenic for human Ig loci, while expression of endogenous Igs was disabled. Upon immunization, this so-called HuMAb-Mouse is a source of antigen-specific human monoclonal $\mathrm{Ab}$ (mAb)-producing lymphocytes. In order to determine if the HuMAb-Mouse is susceptible to EAMG, we immunized the mouse with tAChR. 


\section{Materials and methods}

\section{Immunization}

HuMAb-Mice $(\mathrm{n}=12)$ transgenic for human $\mu, \gamma 1$, and $\kappa$ germ line genes, while production of endogenous immunoglobulins was inactivated[14, 15], were immunized at the base of the tail with $15 \mu \mathrm{g}$ tAChR in CFA and boosted twice with the same dose of tAChR in IFA. Control HuMAb-Mice were immunized with only CFA.

\section{Hybridoma fusion and screening}

Para-aortal lymph node and spleen cells were isolated from all the 12 mice and fused separately with SP2/0 cells for production of hybridomas, according to Köhler and Milstein[16]. Culture supernatants of hybridoma clones were screened for anti-tAChR $\mathrm{mAb}$ production using an ELISA. Microtiter plates were coated with $50 \mu \mathrm{l}$ of $5 \mu \mathrm{g} / \mathrm{ml}$ tAChR in a $10 \mathrm{mM}$ bicarbonate buffer, $\mathrm{pH} 9.5$, for $1 \mathrm{~h}$ at $37^{\circ} \mathrm{C}$. After washing three times with water containing $0.5 \%$ Tween 20 (wash buffer), wells were blocked with $200 \mu \mathrm{PBS}$ containing $0.5 \%$ BSA and $0.5 \%$ Tween 20 (incubation buffer) for $15 \mathrm{~min}$. Subsequently, plates were incubated with a appropriate dilution of hybridoma culture supernatant in incubation buffer for $1 \mathrm{~h}$ at room temperature. After washing, plates were incubated with 1/500 alkaline phosphatase-conjugated goat anti-human IgG (Fc specific) Abs in incubation buffer for $1 \mathrm{~h}$. After washing, $50 \mu \mathrm{l}$ of alkaline phosphatase substrate solution (Bio-Rad Laboratories, Hercules, CA, USA) was added. The colormetric reaction was developed for $30 \mathrm{~min}$ and OD measured at $405 \mathrm{~nm}$.

Anti-AChR Ab serum titer and mAb cross-reactivity

Ab titers against tAChR, human AChR (hAChR) and rat AChR (rAChR) and crossreactivity of mAbs were determined from 9 mouse sera (no sera were obtained from the other 3 animals, wich died after cardiac puncture), by a RIA using ${ }^{125} \mathrm{I}-\alpha$-bungarotoxin $\left({ }^{125} \mathrm{I}-\alpha-\mathrm{BT}\right)$ labeled $\mathrm{AChR}[17]$. AChR - either purified tAChR, crude extract of 
denervated rat muscle, or crude extract of hAChR-producing cell line TE671 - was labeled with $2 \mathrm{nM}{ }^{125} \mathrm{I}-\alpha-\mathrm{BT}$ for $4 \mathrm{~h}$ at $4^{\circ} \mathrm{C}$. A $5 \mu \mathrm{l}$ of serum or $100 \mu \mathrm{l}$ of hybridoma culture supernatant was incubated with $200 \mu{ }^{125} \mathrm{I}-\alpha$-BT-labeled AChR overnight at $4^{\circ} \mathrm{C}$. $\mathrm{Ab}-\mathrm{AChR}$ complexes were precipitated by incubating with excess goat anti-human Ig Abs for $4 \mathrm{~h}$ at $4^{\circ} \mathrm{C}$. After washing with PBS containing $0.5 \%$ Triton-X100 and $0.02 \%$ $\mathrm{NaN}_{3}$, radioactivity was counted in a $\gamma$ counter. Ab titers were expressed as moles of $\alpha-$ BT sites per liter.

\section{Quantification of AChR in muscle}

To quantify the AChR loss in EAMG mice, the concentration of AChR in muscle was determined as previously described[17, 18]. In short, mouse carcasses were minced and homogenized in $150 \mathrm{ml}$ of $10 \mathrm{mM}$ sodium phosphate ( $\mathrm{pH} \mathrm{7.5),100 \textrm {mM } \mathrm { NaN }}, 10 \mathrm{mM}$ iodoacetamide and $1 \mathrm{mM}$ PMSF. Homogenate was centrifuged at $12000 \mathrm{rpm}, 4^{\circ} \mathrm{C}$ for 30 min, and pellet was resuspended in the same buffer above but with $2 \%$ Triton-X100. Extraction was performed for $1 \mathrm{~h}$ at $4^{\circ} \mathrm{C}$ on a shaker. After centrifugation at $12000 \mathrm{rpm}$, $4^{\circ} \mathrm{C}$ for $30 \mathrm{~min}$, the volume of the supernatant was measured and aliquots of $1 \mathrm{ml}$ were labeled with ${ }^{125} \mathrm{I}-\alpha-\mathrm{BT}$, with or without $1 \mathrm{mM}$ acetylcholine and neostigmine-bromide. One $\mu \mathrm{l}$ of pooled high-titer rat anti-AChR serum and normal rat serum were added, and triplicates of $250 \mu \mathrm{l}$ mixture (with or without acetylcholine and neostigmine-bromide) were incubated overnight at $4^{\circ} \mathrm{C}$. Subsequently, $100 \mu$ l goat anti-rat Ig Abs was added and incubated for $4 \mathrm{~h}$ at $4^{\circ} \mathrm{C}$. After centrifugation for $3 \mathrm{~min}$, pellet was washed once with PBS containing $0.5 \%$ Triton-X100 and $0.02 \% \mathrm{NaN}_{3}$ and counted in $\gamma$ counter. AChR concentrations were compared with control animals.

\section{Immunohistochemical staining of muscle}

Muscle biopsies from HuMAb-Mice were frozen in 2-methylbutane, cut at $6 \mu \mathrm{m}$ and fixated with acetone for $10 \mathrm{~min}$ at $4^{\circ} \mathrm{C}$, and air-dried for $5 \mathrm{~min}$. After washing three times with PBS, sections were pre-incubated with PBS containing $2 \%$ BSA for $15 \mathrm{~min}$, and subsequently incubated with 1/100-diluted goat anti-human IgG (Cappel, ICN Pharmaceuticals, Aurora, OH, USA) for $45 \mathrm{~min}$. After washing with PBS, sections were 
further incubated with 1/50 FITC-conjugated rabbit anti-goat Ig Abs (Cappel, ICN Biochemicals, Eschwege, Germany) together with 1/250 rhodamine-conjugated $\alpha$-BT (Molecular Probes, Eugene, OR, USA) for $45 \mathrm{~min}$, in order to co-localize human antiAChR Abs with mouse AChR.

\section{Results}

Induction of EAMG

HuMAb-Mice were immunized with tAChR to determine their susceptibility to EAMG. After the second booster, a few animals showed mild clinical signs of EAMG (grade +, according to Lennon et al[8]). The mice had $\mathrm{Ab}$ titers of anti-tAChR ranging from 7 to $296 \mathrm{nM}$ and of anti-rodent AChR ranging from 155 to $539 \mathrm{pM}$ (Figure 1), indicating a successful immunization with tAChR in all mice. The anti-rAChR/anti-tAChR Ab serum titer ratio was between $0.2 \%$ and $4.0 \%$. Staining of AChR at the neuromuscular junction in muscle sections with rhodamine-conjugated $\alpha$-BT was co-localized with human Abs, visualized with goat anti-human IgG and FITC-conjugated rabbit anti-goat Ig Abs (Figure 2). To determine the damage that was inflicted by the human anti-mouse AChR (mAChR) Abs, the AChR loss in muscles was measured. The AChR contents in the tAChR-immunized mouse muscles were 0 to $65 \%$ lower, compared to control mice (Figure 3). These data clearly demonstrate that HuMAb-Mice were susceptible to EAMG. 

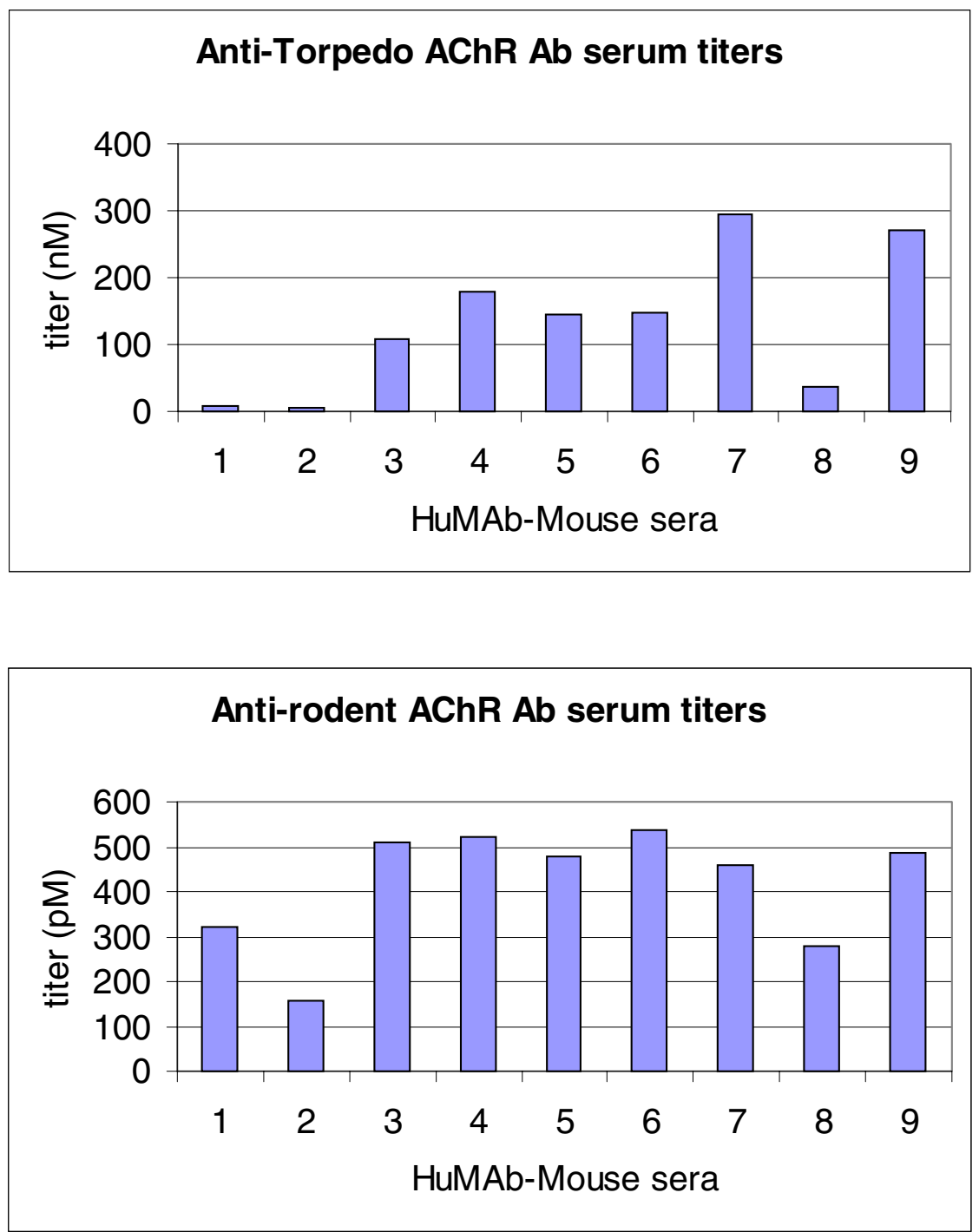

Figure 1 Human anti-AChR Ab serum titers in Torpedo AChR-immunized HuMAb-Mice. Serum titers (moles $\alpha$-bungarotoxin binding sites per liter serum) were measured in 9 mice, by a RIA using ${ }^{125}$ I- $\alpha$-bungarotoxin-labeled Torpedo or rat AChRs. 

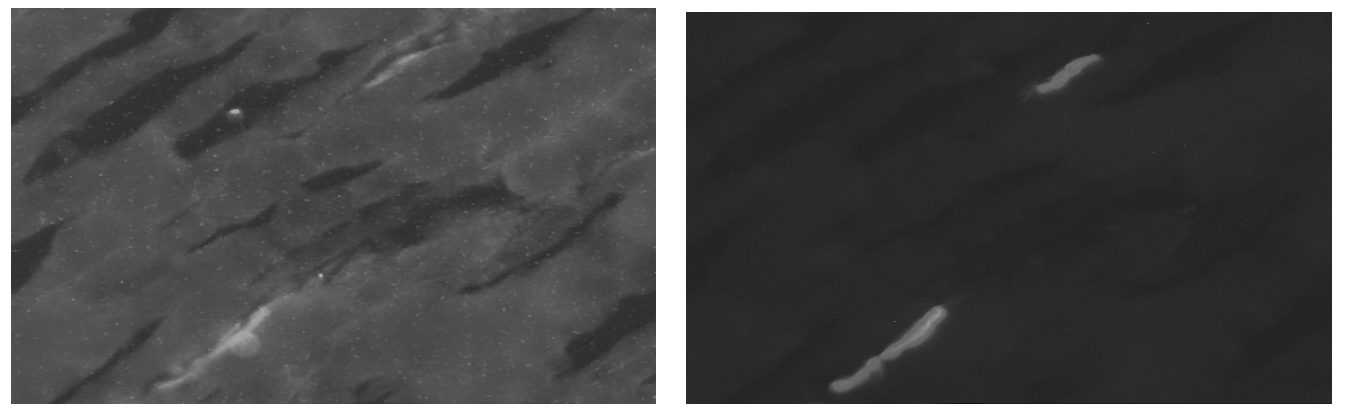

Figure 2 Human $\mathrm{Ab}$-mouse $\mathrm{AChR}$ complexes at the neuromuscular junction of Torpedo AChR-immunized HuMAb-Mice. A cryosection of mouse muscle was double stained with goat anti-human IgG and FITC-conjugated rabbit anti-goat Ig Abs (left panel) and rhodamine-conjugated $\alpha$-bungarotoxin (right panel), co-localizing the AChRs and human antibodies.

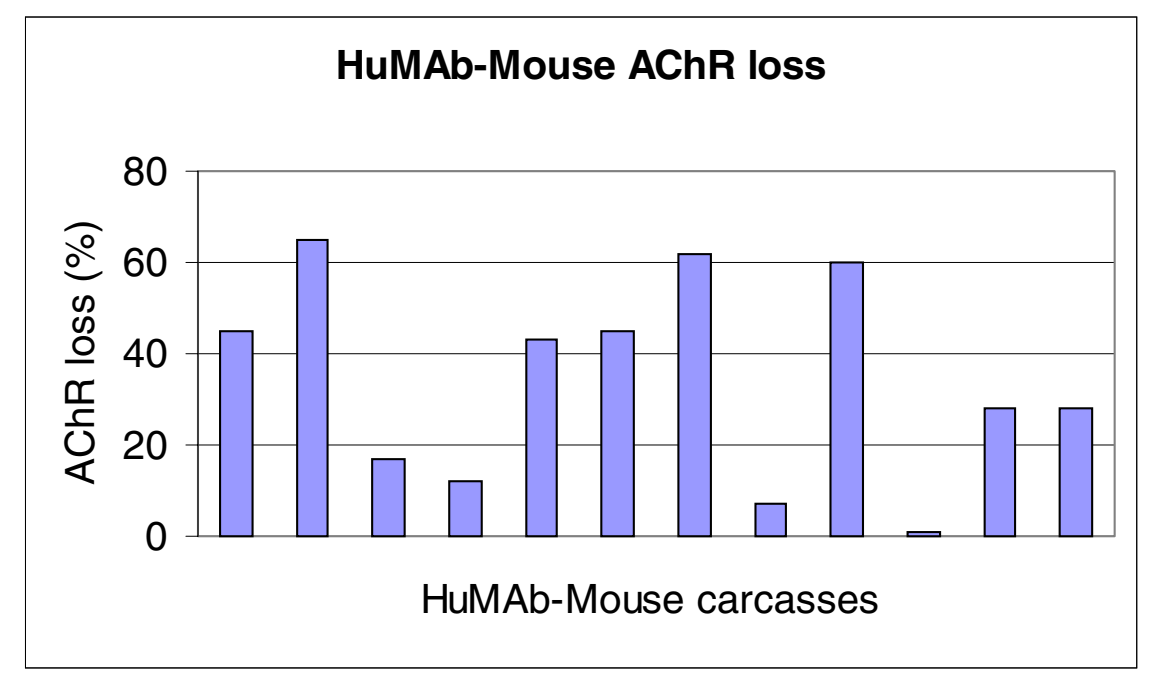

Figure 3 AChR loss in Torpedo AChR-immunized HuMAb-Mice. Total AChR concentrations of mouse muscles were determined in all 12 mice, by immunoprecipitation using ${ }^{125} \mathrm{I}$ - $\alpha$-bungarotoxin, and compared to control animals. (Numbering of animals is not available.) 
Spleens and lymph nodes were isolated for the production of anti-AChR-specific hybridoma cells. Four hundred and thirty-three anti-tAChR mAb-producing clones were selected after initial screening of the hybridomas by ELISA. The number of hybridomas that had cross-reactivity with rodent AChR - those mAbs that were most likely pathogenic in the mice - was $7(2 \%)$, as determined by a RIA. In order to explore the possibility of a human mAb cross-reacting with $\mathrm{hAChR}$, that could be used for studying MG immunotherapy, a hAChR-specific RIA was performed. However, no mAb could bind hAChR with high specificity (Table 1).

Table 1 Specificities of mAbs produced by Torpedo AChR-immunized HuMAb-Mouse hybridomas

\begin{tabular}{cc}
\hline mAb & number $(\%)$ \\
\hline anti-Torpedo AChR & $433(100)$ \\
anti-rodent AChR & $7(2)$ \\
anti-human AChR & $0(0)$ \\
\hline
\end{tabular}

Cross-reactivity of human anti-Torpedo AChR mAbs was determined by ${ }^{125} \mathrm{I}-\alpha-$ bungarotoxin-labeled AChR immunoprecipitation.

\section{Discussion}

The establishment of mice transgenic for human Ig loci makes it possible to set up a new mouse EAMG model, in which the mice produce human anti-AChR Abs upon immunization with AChR from various species. In the study presented here, transgenic HuMAb-Mice, which produce human $\operatorname{IgG1} \kappa$ and $\operatorname{IgM\kappa }$ molecules, were immunized with tAChR extracted from Torpedo californica, a rich source of AChR commonly used in mammalian study of MG. After the second booster injection of tAChR, the anti-tAChR 
and -rodent AChR Ab titers were determined, and the clinical signs of EAMG examined to evaluate if a successful EAMG model had been established.

It was found that serum titers of Abs against tAChR, an initial immunogen, were in the nanomolar range, similar to those found in MG patients[19], and approximately a hundred-fold higher than those observed in the MG thymus tissue-transplanted model[10], in which the original immunogen should be hAChR. The difference in the serum $\mathrm{Ab}$ titers between the $\mathrm{C} 57 \mathrm{bl} / 6$ mice, immunized with tAChR[12] and the HuMAbMice may reflect the strain-dependent susceptibilities to the induction of EAMG. The anti-rAChR Ab serum titer, ranging from $0.2 \%$ to $4.0 \%$ of that to tAChR, is comparable to the findings in other mouse strains[11].

The clinical signs of muscular weakness, a key symbol of EAMG, were successfully induced in some of the HuMAb-Mice, directly indicating that the EAMG had been established. This was further demonstrated by the deposits of human anti$\mathrm{mAChR}$ Abs at the neuromuscular junction of muscle sections, as detected by goat antihuman IgG, and by the muscle AChR loss up to 65\%. Human anti-AChR Abs can bind to the postsynaptic membrane, and reduce the amount of mAChR, which interferes with the neuromuscular transmission. In contrast, the thymus tissue- or its single-cell suspensionstransplanted model is not accompanied by muscular weakness[10].

The $\mathrm{Ab}$ repertoire was analyzed by hybridoma technology. From tAChRimmunized HuMAb-Mice, hybridomas were made and initially screened for the reactivity to tAChR. Of those reactive with tAChR, $2 \%$ cross-reacted with $\mathrm{rAChR}$ and none with hAChR. This result is consistent with our previous study, in which we found a similar pattern of cross-reaction in the high-susceptible C57bl/6 and the low-susceptible Balb/c mice[12], and failed to find anti-hAChR mAbs from tAChR-immunized mice (see Chapter 1, Table 1). Since the tAChR immunization did not generate a set of high-affinity human anti-hAChR mAbs, we are planning to immunize HuMAb-Mice with a recombinant peptide of the hAChR with native conformation[20]. These human antihAChR Abs could be used, after modification or fragmentation, as treatment for exacerbation of MG.

Our HuMAb-Mouse EAMG model is the first model in which human Abs were actively induced in mice, permitting the study of human tAChR-induced Abs. This chronic model resembles MG more closely, and holds promise for the development of a 
more appropiate mouse model with an entire human immune response, including human Igs, MHC and AChR genes.

\section{Acknowledgement}

We would like to thank Dr B. Machiels for excellent laboratory assistance and helpful discussions.

\section{References}

1 Patrick J, Lindstrom J. Autoimmune response to acetylcholine receptor. Science, 1973, 180: $871-872$

2 Almon RR, Andrew CG, Appel SH. Serum globulin in myasthenia gravis: inhibition of $\alpha$-bungarotoxin binding to acetylcholine receptors. Science, 1974, 186: 55-57

3 Lang B, Richardson G, Rees J, Vincent A, Newsom-Davis J. Plasma from myasthenia gravis patients reduces acetylcholine receptor agonist-induced $\mathrm{Na}^{+}$flux into TE671 cell line. J Neuroimmunol, 1988, 19: 141-148

4 Engel AG, Lambert EH, Howard FM. Immune complexes (IgG and C3) at the motor endplate in myasthenia gravis. Ultrastructural and light microscopic localization and electrophysiologic correlations. Mayo Clin Proc, 1977, 52: 267-280

5 Lennon VA, Seybold ME, Lindstrom JM, Cochrane C, Ulevitch R. Role of complement in the pathogenesis of experimental autoimmune myasthenia gravis. $J$ Exp Med, 1978, 147: 973-983

6 Kao I, Drachman DB. Myasthenic immunoglobulin accelerates acetylcholine receptor degradation. Science, 1977, 196: 527-529

7 Heineman S, Bevan S, Kullberg R, Lindstrom J, Rice J. Modulation of acetylcholine receptor by antibody against the receptor. Proc Natl Acad Sci USA, 1977, 74: 30903094 
8 Lennon VA, Lindstrom JM, Seybold ME. Experimental autoimmune myasthenia: a model of myasthenia gravis in rats and guinea pigs. J Exp Med, 1975, 141: 1365-1375

9 Toyka KV, Brachman DB, Pestronk A, Kao I. Myasthenia gravis: passive transfer from man to mouse. Science, 1975, 190: 397-399

10 Schönbeck S, Padberg F, Hohlfeld R, Wekerle H. Transplantation of thymic autoimmune microenvironment to severe combined immunodeficiency mice. J Clin Invest, 1992, 90: 245-250

11 Berman PW, Patrick J. Experimental myasthenia gravis. A murine system. $J$ Exp Med, 1980, 151: 204-223

12 Graus YM, van Breda Vriesman PJ, de Baets MH. Characterization of antiacetylcholine receptor (AChR) antibodies from mice differing in susceptibility for experimental autoimmune myasthenia gravis (EAMG). Clin Exp Immunol, 1993, 92: 506-513

13 Raju R, Zhan W-Z, Karachunski P, Conti-Fine B, Sieck GC, David C. Polymorphism at the HLA-DQ locus determines susceptibility to experimental myasthenia gravis. $J$ Immunol, 1998, 160: 4169-4174

14 Lonberg N, Taylor LD, Harding FA, Trounstine M, Higgins KM, Schramm SR, Kuo C-C, Mashayekh R, Wymore K, McCabe JG, Munoz-O'Regan D, O’Donnell SL, Lapachet ESG, Bengoechea T, Fishwild DM, Carmack CE, Kay RM, Huszar D. Antigen-specific human antibodies from mice comprising four distinct genetic modifications. Nature, 1994, 368: 856-859

15 Fishwild DM, O’Donnell SL, Bengoechea T, Hudson DV, Harding F, Bernhard SL, Jones D, Kay RM, Higgins KM, Schramm SR, Lonberg N. High-avidity IgGK monoclonal antibodies from a novel strain of minilocus transgenic mice. Nat Biotechnol, 1996, 14: 845-851

16 Köhler G, Milstein C. Continuous cultures of fused cells secreting antibody of predefined specificity. Nature, 1975, 256: 495-497

17 Lindstrom JM, Einarson BL, LennonVA, Seybold ME. Pathological mechanisms in experimental autoimmune myasthenia gravis. I. Immunogenicity of syngeneic muscle acetylcholine receptor and quantative extraction of receptor and antibody-receptor complexes from muscles of rats with experimental autoimmune myasthenia gravis. $J$ Exp Med, 1976, 144: 726-738 
18 Verschuuren JJGM, Graus YMF, Theunissen ROM, Yamamoto T, Vincent A, van Breda Vriesman PJC, de Baets MH. Role of acetylcholine receptor antibody complexes in muscle in experimental autoimmune myasthenia gravis. $J$ Neuroimmunol, 1992, 36: 117-125

19 Graus YF, de Baets MH, Parren PWHI, Berrih-Aknin S, Wokke J, van Breda Vriesman PJ, Burton DR. Human anti-nicotinic acetylcholine receptor recombinant Fab fragments isolated from thymus-derived phage display libraries from myasthenia gravis patients reflect predominant specificities in serum and block the action of pathogenic serum antibodies. J Immunol, 1997, 158: 1919-1929

$20 \mathrm{Im}$ SH, Barchan D, Souroujon MC, Fuchs S. Role of tolerogen conformation in induction of oral tolerance in experimental autoimmune myasthenia gravis. $J$ Immunol, 2000, 165: 3599-3605 


\section{Summary and general discussion}

Myasthenia gravis (MG) is an organ-specific autoimmune disease mediated by autoantibodies directed against acetylcholine receptor (AChR). The $\mathrm{AChR}$ is a well characterized transmembrane glycoprotein, consisting of five subunits $\alpha_{2} \beta \gamma \delta$ or $\alpha_{2} \beta \varepsilon \delta$. A cross-linking of an extracellular region, termed the main immunogenic region (MIR), of $\alpha$-subunit in AChR at neuromuscular junction by bivalent antibody leads to accelerated internalization of AChR (antigenic modulation), or activation of complement (focal lysis), resulting in muscle weakness. Less importantly, antibodies binding to acetylcholine (ACh) binding site or $\alpha$-bungarotoxin $(\alpha-\mathrm{BT})$ binding site directly interfere with the ion channel function. The animal model of MG, experimental autoimmune myasthenia gravis (EAMG), can be induced by active immunization with purified AChR or passive transfer of anti-AChR antibodies.

Anti-MIR antibodies are found to make up $60 \%$ of the total anti-AChR antibodies in MG patient sera or EAMG rat sera, thus are major pathogenic autoantibodies in pathogenesis of MG or EAMG. The contribution of individual pathogenic anti-AChR antibodies to the AChR loss is important for understanding the pathogenesis of MG or EAMG. Further structural and functional analysis of pathogenic and non-pathogenic antiAChR antibodies may lead to the better understanding.

Single chain variable fragments $(\mathrm{ScFv})$ of antibody are univalent, and can not themselves cross-link AChR and can not activate complement. However, ScFv derived from anti-MIR antibodies can bind to MIR on AChR, just protecting the MIR against the binding of pathogenic anti-MIR antibodies. ScFv derived from human does not possess immunogenicity for application in patients, and readily undergoes genetic manipulation in improvement of stability and affinity. 
The establishment of mice transgenic for human immunoglobulin loci makes it possible to set up a new mouse EAMG model. This model is expected to be the first step towards an ideal EAMG model of mice transgenic for human immunoglobulin and HLA loci, and a source of human anti-AChR antibodies.

In Chapter 1, an EAMG mouse model was used to produce monoclonal antibodies (mAbs) directed against AChR. C57bl/6 and Balb/c mice were immunized with purified Torpedo AChR (tAChR) and human AChR (hAChR), and boosted 3 and 5 weeks after primary immunization. The mice were sacrificed 3 days after the last injection and cells from lymphnodes were fused with mouse myeloma cell line SP2/O-Ag14 or NS1. Hybridomas were initially screened for reactivity to AChR by ELISA. Most of the anti$\mathrm{AChR} m A$ bs were found to be $\mathrm{IgG} 1$ and $\mathrm{IgG} 2 \mathrm{~b}$ as determined by a mouse isotyping kit, and some of them were cross-reactive with mouse and rat AChR as showed in radioimmunoassay (RIA) using mouse and rat muscle crude extracts as antigens. Determination of fine specificity of the anti-AChR mAbs binding to $\mathrm{AChR}$ using competitive ELISA or RIA showed that four different groups of the mAbs were identified: anti-MIR mAbs (rat anti-MIR mAbs 35 as reference competitor), anti- $\alpha-B T$ binding site mAbs ( $\alpha$-BT as reference competitor), anti-extracellular epitope mAbs and anti-intracellular epitope mAbs.

In Chapter 2, the role of different anti-AChR antibody sequences and specificities in pathogenesis of EAMG was investigated by sequencing a panel of 6 anti-MIR mAbs. The EAMG was induced in rats or mice by passive transfer of the mAbs and evaluated by clinical signs and AChR loss. The variable regions of heavy and light chains of anti-MIR mAbs were sequenced. Comparison of the sequences at nucleotide and amino acid levels between the mAbs showed that they utilized a similar $\mathrm{VH}$ gene derived from mouse PC7183 germline family with high homology in complementarity determining region (CDR) 1 and 2. The large diversity found in heavy chain CDR3 of the anti-MIR mAbs may contribute to the difference in pathogenicity of the mAbs.

In Chapter 3, a panel of 3 anti- $\alpha$-BT binding site mAbs were investigated on their epitope specificity and their nucleotide and deduced amino acid sequences of variable 
regions. The three mAbs recognized the same epitope on AChR as showed in a competitive inhibition assay between individual mAbs. The sequence analysis of the mAbs showed that they all utilized the same VH gene derived from mouse Q52 germline family, but different VL genes, indicating that the heavy chain play more important role in binding to AChR. Comparison of sequences between the anti- $\alpha$-BT binding site mAbs and the pathogenic anti-MIR mAb revealed that a large diversity was observed in both overall sequences and CDRs.

In Chapter 4, an human ScFv637 was constructed from its parental Fab637, previously isolated from thymus-derived phage display library with specificity of anti-MIR of hAChR, by PCR amplification. PCR products of VH and VL genes of Fab637 were assembled onto vector phagemid pHEN2 containing GS rich linker and c-myc tag and 6x His tag at C-terminus for specific detection and for efficient purification. The recombinant pHEN2-ScFv637 construct was transformed into E coli HB2151 for soluble production of $\mathrm{ScFv}$ after induction with IPTG. ScFv637 was efficiently produced in periplasmic fraction but not in culture supernatant of bacteria as detected by nitrocellulose dot blot using mouse anti-cmyc mAb. ScFv637 was able to bind to hAChR in standard precipitation RIA. ScFv637 could also bind to monkey AChR in situ on monkey neuromuscular junction as showed in immunohistochemical staining. Furthermore, ScFv637 was capable of inhibiting the binding of its intact IgG637 and antiMIR mAb35 to hAChR up to $32.9 \%$ and $73.0 \%$ respectively demonstrated in a competitive ELISA, and of MG patient sera from $27.8 \%$ to $45.5 \%$ in a competitive RIA. Therefore, ScFv637, easier for manipulation in improvement of affinity and stability compared with its parental Fab637, may serve as an alternative candidate for specific immunotherapy in MG.

In Chapter 5, a new EAMG mouse model, that generates human anti-AChR antibodies, was reported. Mice transgenic for human $\mu, \gamma 1$, and $\kappa$ germ line genes (HuMAb-Mice) were immunized with tAChR. Serum titers of anti-tAChR antibodies were in the nanomolar range, and anti-rodent $\mathrm{AChR}$ antibodies were in picomolar range. Human antibody-mouse AChR complexes were found at the neuromuscular junction, while AChR loss was up to $65 \%$. Some HuMAb-Mice had mild signs of muscle weakness, 
clearly indicating their susceptibility to EAMG. Spleen and lymph nodes were used for producing hybridomas. From the anti-tAChR mAb-producing hybridomas $2 \%$ had crossreactivity with rodent AChR. These experiments show that the HuMAb-Mouse represents a suitable model to study the effects of human anti-AChR antibodies in vivo.

The results from the first part of the study (Chapters 1 to 3) indicate that the pathogenic anti-AChR antibodies are exclusively among the mAbs which are directed against MIR, and most of anti-MIR mAbs utilize a VH gene derived from mouse PC7183 germline family. Furthermore, The CDR sequences are different between pathogenic and nonpathogenic anti-MIR mAbs, and between pathogenic anti-MIR mAbs and anti- $\alpha$-BT binding site mAbs, and CDR3 of heavy chain may contribute to the pathogenicity of the mAbs. This conclusion will form the basis for the genetic manipulation of ScFv637, an alternative candidate for specific immunosuppressive therapy of MG described in the second part of the study (Chapter 4), in order to improve its affinity and stability. The experiment from the third part of the study (Chapter 5) demonstrates that mice transgenic for human immunoglobulin loci is a suitable model to investigate human antiAChR antibodies in vivo, which holds promise for the development of an ideal mouse model with entire human immune response. 


\section{Samenvatting en algemene discussie}

Myasthenia gravis (MG) is een orgaanspecifieke auto-immuunziekte die wordt gemedieerd door autoantilichamen gericht tegen de acetylcholinereceptor (AChR). De $\mathrm{AChR}$ is een goed gekarakteriseerd transmembraaneiwit, bestaande uit vijf subunits: $\alpha_{2} \beta \gamma \delta$ of $\alpha_{2} \beta \gamma \varepsilon$. Het verbinden van twee identieke epitopen van de zogenaamde main immunogenic region (MIR), gelegen op de $\alpha$-subunit van de $\mathrm{AChR}$, door bivalente antilichamen in de neuromusculaire junctie leidt tot versnelde internalisatie van de AChR (antigenic modulation), wat resulteert in spierzwakte. Complementactivering (focale lysis) en, in mindere mate, interferentie met de functie van het ionkanaal door binding van antilichamen aan de acetylcholine- of $\alpha$-bungarotoxinebindingsplaats geven hetzelfde resultaat. Het diermodel van MG, experimentele auto-immuun MG (EAMG), kan worden geïnduceerd door actieve immunisering met gezuiverd AChR of door passieve overdracht met anti-AChR antilichamen.

Anti-MIR antilichamen beslaan tot $60 \%$ van het totaal aan anti-AChR antilichamen in MG-patiëntensera of EAMG-rattensera; ze zijn dus belangrijke pathogene autoantilichamen in de pathogenese van MG of EAMG. De bijdrage van individuele pathogene anti-AChR antilichamen aan het AChR-verlies is van belang voor het begrijpen van de pathogenese van MG of EAMG. Verdere structurele en functionele analyses van pathogene en niet-pathogene anti-AChR antilichamen kan leiden tot een beter inzicht.

Single-chain variabele fragmenten (scFv's) van antilichamen zijn univalent en kunnen geen AChR's crosslinken en complement activeren. Echter, scFv's die zijn afgeleid van anti-MIR antilichamen kunnen aan de MIR binden en daarmee de AChR afschermen tegen binding van pathogene anti-MIR antilichamen. ScFv's die zijn afgeleid van humane antilichamen zijn niet immunogeen voor toepassingen in patiënten en 
kunnen gemakkelijk genetisch worden gemodificeerd voor het verbeteren van de stabiliteit en affiniteit.

De ontwikkeling van muizen die transgeen zijn voor humane immunoglobulinenloci heeft het mogelijk gemaakt om een nieuw muizen EAMG-model op te zetten. Dit model is waarschijnlijk de eerste stap naar een ideaal EAMG-model, van muizen transgeen voor humane immunoglobulinen- en HLA-loci, en daarnaast een bron voor humane anti-AChR antilichamen.

In hoofdstuk 1 werd een EAMG-muizenmodel gebruikt voor de productie van monoklonale antilichamen (mAb's) gericht tegen AChR. C57b1/6 en Balb/c muizen werden geïmmuniseerd met gezuiverde Torpedo AChR (tAChR) en humane AChR (hAChR) en na drie en vijf weken geboost. De muizen werden drie dagen na de laatste injectie opgeofferd en de cellen van de lymfeknopen werden gefuseerd met muis myelomacellijn SP2/O-Ag14 of NS1. Hybridoma's werden onderzocht op reactiviteit tegen AChR met ELISA. De meeste anti-AChR mAb's waren van het IgG1- of IgG2bisotype en enkele hadden kruisreactiviteit met muis en rat $\mathrm{AChR}$, zoals aangetoond met een radio-immunoassay (RIA) met muis of rat spierextracten als antigeen. Middels een competitieve ELISA en RIA, werden de anti-AChR mAb's naar specificiteit ingedeeld: anti-MIR mAb's (met rat anti-MIR mAb 35 als referentiecompetitor), anti- $\alpha$ bungarotoxinebindingsplaats mAb's (met $\alpha$-bungarotoxine als referentiecompetitor), anti-extracellulair epitoop mAb's en anti-intracellulair mAb's.

In hoofdstuk 2 werd de rol onderzocht van verschillende anti-AChR antilichaamsequenties en -specificiteiten in de pathogenese van EAMG, middels het bepalen van de sequentie van een panel van zes anti-MIR mAb's. EAMG werd geïnduceerd in ratten of muizen middels passieve overdracht met de mAb's en geëvalueerd op klinische kenmerken en AChR-verlies. De variabele regio's van de zware en lichte ketens van de anti-MIR mAb's werden gesequenced. Uit het vergelijken van de sequenties op nucleotide- en aminozuurniveau, bleek dat de mAb's eenzelfde VH-gen bezitten, uit de muis PC7183 kiemlijnfamilie, met hoge homologie in de complement determining region (CDR) 1 en 2. De grote diversiteit in de CDR3's van de zware ketens zou kunnen bijdragen aan de verschillen in pathogeniciteit van de mAb's. 
In hoofdstuk 3 werd een panel van drie anti- $\alpha$-bungarotoxinebindingsplaats mAb's onderzocht op de epitoopspecificiteit en de nucleotidesequentie en de daarvan afgeleide aminozuursequentie van de variabele regio. De drie mAb's herkennen hetzelfde epitoop op de AChR, zoals aangetoond met een competitieve inhibitie-assay tussen de afzonderlijke mAb's. De sequentie-analyse van de mAb's wees uit dat de VH-genen afstamden van de muis Q52-kiemlijnfamilie, terwijl de VL-genen verschilden. Dit duidt er op dat de zware ketens een belangrijkere rol spelen in de binding aan AChR. Het vergelijken van de sequenties van anti- $\alpha$-bungarotoxinebindingsplaats $m A b$ 's en de pathogene anti-MIR mAb duidde op een grote diversiteit in sequenties en CDR's in beide groepen.

In hoofdstuk 4 werd het humane scFv637 geconstrueerd middels PCR-klonering uit Fab637, die eerder was geïsoleerd uit een faagdisplaybibliotheek met specificiteit voor de humane MIR. PCR-producten van de VH- en VL-genen van Fab637 werden gekloneerd in het vector faagmide pHEN2, die een GS-rijke linker en een C-terminale c-myc- en een 6xHis-tag heeft voor specifieke detectie en efficiënte zuivering. Het recombinante construct pHEN2-scFv637 werd getransformeerd in E. coli-stam HB2151 voor de productie van oplosbare scFv's, na inductie met IPTG. ScFv637 werd efficiënt geproduceerd in de periplasmatische fractie, maar niet in het kweeksupernatant, zoals aangetoond met een nitrocellulose dotblot met een muis anti-c-myc mAb. ScFv637 was in staan hAChR te precipiteren in een RIA. Daarnaast kon scFv637 ook aap AChR binden in situ, zoals immunohistochemisch aangetoond in aap neuromusculaire juncties. Bovendien had scFv637 de capaciteit om de binding van IgG637 en anti-MIR mAb35 aan hAChR te inhiberen met percentages tot respectievelijk 32,9 en 73,0 - aangetoond met competitieve ELISA - en om de binding van MG-patiëntensera te inhiberen met 27.8 tot $45.5 \%$ - competitieve RIA. Daarom is scFv637, ook gezien het gemakkelijker manipuleren ter verbetering van affiniteit en stabiliteit in vergelijking tot Fab637, een alternatieve kandidaat voor specifieke immunotherapie van MG.

In hoofdstuk 5 werd een nieuw EAMG-muismodel beschreven, dat humane anti-AChR antilichamen genereert. Muizen transgeen voor $\mu$-, $\gamma 1$ - en $\kappa$-kiemlijngenen (HuMAb- 
Mice) werden geïmmuniseerd met tAChR. Serumtiters van anti-tAChR antilichamen waren in het nanomolaire bereik en de anti-knaagdier AChR antilichamen in de picomolaire bereik. Humaan antilichaam-muis AChR-complexen weren gevonden ter hoogte van de neuromusculaire junctie, terwijl AChR-verlies opliep tot $65 \%$. Enkele HuMAb-Mice hadden lichte symptomen van spierzwakte, er op duidend dat ze vatbaar zijn voor EAMG. Milt en lymfeknopen werden gebruikt voor de productie van hybridoma's. Van de anti-tAChR mAb-producerende hybridoma's vertoonde $2 \%$ kruisreactiviteit met knaagdier AChR. Deze experimenten tonen aan dat de HuMAbMouse een geschikt model is voor het bestuderen van de effecten van humane anti-AChR antilichamen in vivo.

De resultaten van het eerste gedeelte van deze studie (hoofdstuk 1 tot en met 3) tonen aan dat de pathogene anti-AChR antilichamen uitsluitend voorkomen onder de mAb's die zijn gericht tegen de MIR en dat de meeste anti-MIR mAb's een VH-gen gebruiken dat afstamt van de muis PC7183-kiemlijnfamilie. Bovendien zijn de CDR-sequenties verschillend tussen pathogene en niet-pathogene anti-MIR mAb's en tussen pathogene anti-MIR mAb's en anti- $\alpha$-bungarotoxinebindingsplaats mAb's; en de CDR3 van de zware keten kan bijdragen aan de pathogeniciteit van de mAb's. Deze conclusie vormt de basis voor de genetische modificatie ten behoeve van verbetering van de stabiliteit en affiniteit van scFv637, een alternatieve kandidaat voor de specifieke immunosuppressietherapie van MG, beschreven in het laatste gedeelte van dit onderzoek (hoofdstuk 4). De experimenten van het derde deel van de studie (hoofdstuk 5) tonen aan dat muizen die transgeen zijn voor humane immunoglobulinenloci geschikt zijn als model voor het onderzoeken van humane anti-AChR antilichamen in vivo. Dit is belovend in de ontwikkeling van een ideaal muismodel met een volledige humane immuunrespons. 


\section{Publications}

Graus Y, Meng F, Vincent A, van Breda Vriesman P, de Baets M. Sequence analysis of anti-AChR antibodies in experimental autoimmune myasthenia gravis. J Immunol, 1995, 154: 6382-6396

Terwel D, Prickaerts J, Meng F, Jolles J. Brain enzyme activities after intracerebroventricular injection of streptozotocin in rats receiving acetyl-L-carnitine. Eur J Pharmacol, 1995, 287: 65-71

Prickaerts J, Blokland A, Honig W, Meng F, Jolles J. Spatial discrimination learning and choline acetyltransferase activity in streptozotocin-treated rats: effects of chronic treatment with acetyl-L-carnitine. Brain Res, 1995, 674: 142-146

Meng F, Graus Y, Vincent A, de Baets M. Pathogenicity and sequence analysis of a mouse monoclonal antibody against human acetylcholine receptor. Chin J Neurol, 1996, 29: $283-285$

Meng F, Graus Y, de Baets M. Pathogenicity and sequence analysis of a mouse antiAChR monoclonal antibody A7. Chin J Microbiol Immunol, 1996, 16: 45-48

Meng F, Graus Y, de Baets M. Paratope specificity and sequence analysis of monoclonal antibodies against acetylcholine receptor. Immunological J, 1996, 12: 113116 
Meng F, Graus Y, de Baets M. Sequence analysis of antibodies against $\alpha$-bungarotoxin binding sites on acetylcholine receptor. Chin J Immunol, 1996, 12: 295-298

Terwel D, Bothmer J, Wolf E, Meng F, Jolles J. Affected enzyme activities in Alzheimer's disease are sensitive to antemortem hypoxia. J Neurol Sci, 1998, 161: 47-56

Meng F, Graus Y, de Baets M. Pathogenicity and sequence analysis of a mouse monoclonal antibody against human acetylcholine receptor in myasthenia gravis. Immunological J, 1999, 15: 1-4

Stassen M, Gerritsen A, Meng F, van Dijk M, van de Winkel J, de Baets M. Experimental autoimmune myasthenia gravis in mice expressing human immunoglobulins (HuMAb-Mice). Immunobiology, 2000, 203: 226-227

Meng F, Stassen M, Schillberg S, Fischer R, de Baets M. Construction and characterization of a single chain antibody fragment derived from thymus of a patient with myasthenia gravis. Submitted 


\section{Acknowledgements}

This thesis would not have been as it is now without the contribution of a great number of people.

First of all, I would like to thank my promoters Prof Jaap Troost and Prof Harry Steinbusch for the opportunity they gave me to develop the thesis. Dear Jaap and Harry, thank you a lot for your kind direction, and studying in your departments was obviously my honor. This thesis was actually designed by my co-promoter Dr Marc de Baets. Dear Marc, it would not have been possible for me to finish the thesis without your direct guidance and generous support. Getting to know you in 1992 was really my lucky chance. From you I have learned quite a lot both scientifically and personally. Working with you was my greatest scientific experience. Thank you so much not only for your kind guidance in my research in your laboratory but also for your kind help in my living in Belgium and in The Netherlands.

Special thanks go to Dr Yvo Graus. Dear Yvo, thank you very much for your collaboration, which resulted in Chapters 1 to 3 of the thesis. It was you who taught me to perform the experiments with new techniques as well as with new mind. Working with you was always a joy. As everyone in Department of Immunology did, I like you too. I hope I can find words to express my thanks to you. Special thanks also go to Maurice Stassen. Dear Maurice, thank you very much for your collaboration too, which lead to Chapters 4 and 5 of the thesis, and translation of summary and general discussion. Working and sharing an office with you was my pleasure. From you I have known a lot the experiments about single chain antibody fragments and the Dutch culture, which is also nice knowledge for me. I also wish to thank Ruud Aarts, Barbie Machiels, Astrid 
Hoedemaekers, Maria Vroomen for their assistance and helpful discussions, and the persons mentioned in previous chapters for providing experimental materials.

I am grateful to Prof Jellemer Jolles and Prof Peter van Breda Vriesman for kindly supporting me. I am also grateful to my old colleagues Dick Terwel, Jos Prickaerts, John Bothmer, Jan de Vente, Arjan Blokland, Marjanne Markerink, Wiel Honig, Hellen Steinbusch (Department of Psychiatry and Neuropsychology) and Adrian Duijvenstijn, Jan Damoiseaux, José van de Gaar, Henk van Rie, Ruud Theunissen, Lucienne Debrus, Mia Vaessen, Leo Beijleveld, Chris Nieuwenhof, Wiel Wodzig, Josien Derhaag (Department of Immunology), and new coworkers Anton de Louw, Monique Mulder, Arjan Scheepens, Wilma van Staveren, Wilma van de Berg, Charlotte Teunissen, Gunter Kenis, Karlygash Abildayera, Cindy Lieben (Department of Psychiatry and Neuropsychology) for their friendly hospitality, timely help and valuable discussion.

Lilian Swaen, Nicole Senden, Francien Teng and Elsa Misdom are definitely acknowledged for their making everything convenient for me.

I mentioned above all the people who contributed to the development of the thesis in order better to keep their names in my mind whenever I review the thesis.

Finally, I greatly appreciate the encouragement from my wife Kangjuan Yang and my son Xiangwei Meng, which enabled me to feel confident in studying and living in Maastricht, The Netherlands. 


\section{Curriculum vitae}

Fanping Meng was born on December 16, 1958 in Linkou, Heilongjiang Province, P. R. China. From September 1979 to July 1984, he studied medicine as an undergraduate in Yanbian University College of Medicine, China and gained the Bachelor of Medicine degree. From September 1984 to July 1987, he was a postgraduate in the the Department of Microbiology and Immunology, Yanbian University College of Medicine, China and gained the Master of Medicine degree. Then he worked as an assistant and lecturer in the Department of Microbiology and Immunology, Yanbian University College of Medicine, China. From May 1992 to October 1994, he studied as a PhD student in the Department of Immunology ( $\mathrm{Dr}$ Marc de Baets), and the Department of Psychiatry and Neuropsychology (Prof Harry Steinbusch and Prof Jellemer Jolles), University of Maastricht, The Netherlands. He went back to China in 1994 and was appointed as associate professor in 1995, and professor and head of the Department of Microbiology and Immunology, Yanbian University College of Medicine, China in 1998. From May 2000 to May 2001, he continued his study as a $\mathrm{PhD}$ student in the Department of Neurology, Institute of Brain and Behaviour, and the European Graduate School of Neuroscience (EURON), University of Maastricht, The Netherlands under the direction of Prof Jaap Troost, Prof Harry Steinbusch and Dr Marc de Baets. 